\title{
Influência do campo de ventos e do meandramento da Corrente do Brasil na concentração de clorofila- $a$ e nutrientes ao largo de Ubatuba - SP
}

\author{
Dissertação apresentada ao \\ Instituto Oceanográfico da \\ Universidade de São Paulo, como \\ parte dos requisitos para obtenção \\ do título de Mestre em Ciências, \\ Programa de Oceanografia, área \\ de Oceanografia Biológica
}

Orientador Prof. Dr. Frederico Pereira Brandini

São Paulo 


\title{
Influência do campo de ventos e do meandramento da Corrente do Brasil na concentração de clorofila- $a$ e nutrientes ao largo de Ubatuba - SP
}

\author{
PEDRO PAULO GUY MARTINS DOS SANTOS
}

Dissertação apresentada ao Instituto Oceanográfico da Universidade de São Paulo, como parte dos requisitos para obtenção do título de Mestre em Ciências, área de

Oceanografia Biológica.

Julgada em

$\operatorname{Prof}(a) . \operatorname{Dr}(a)$.

Conceito

Prof(a). Dr(a).

Conceito

Prof(a). Dr(a).

Conceito

$\operatorname{Prof}(\mathrm{a}) . \operatorname{Dr}(\mathrm{a})$.

Conceito

$\operatorname{Prof}(\mathrm{a}) . \operatorname{Dr}(\mathrm{a})$.

Conceito 


\section{Sumário}

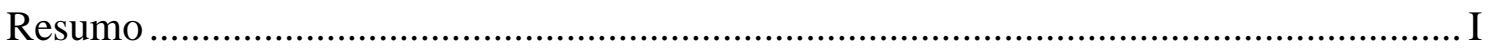

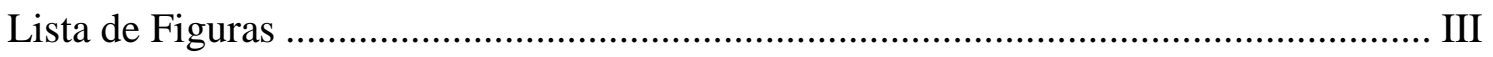

Lista de Tabelas ..................................................................................................

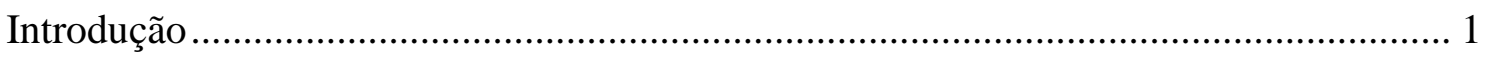

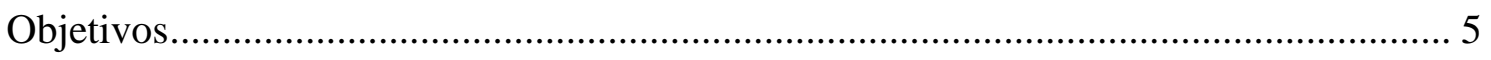

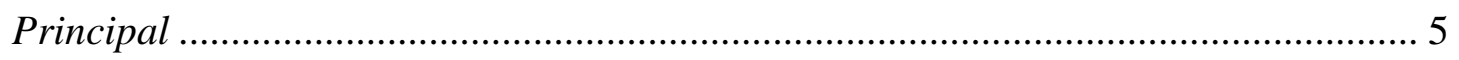

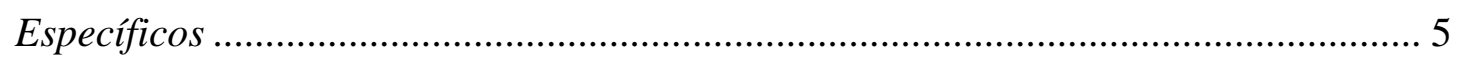

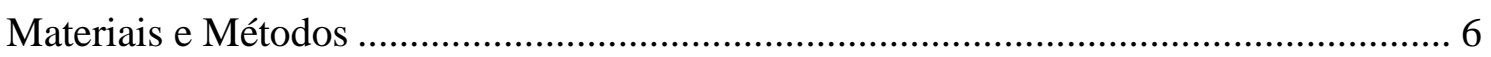

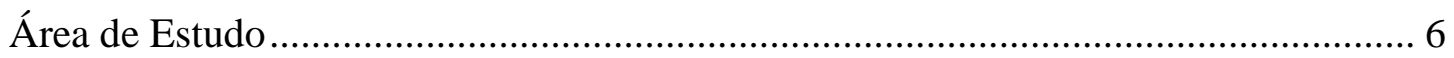

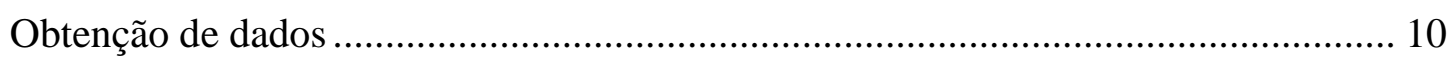

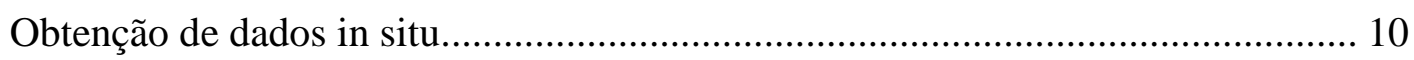

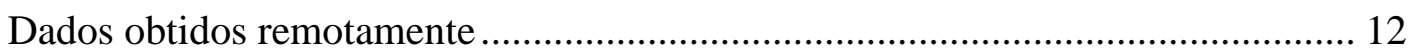

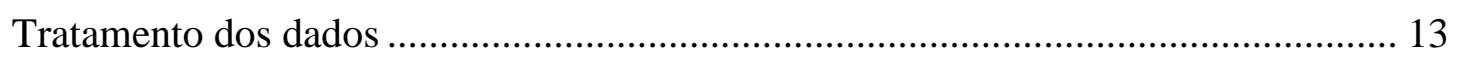

Parametrização dos processos ......................................................................... 13

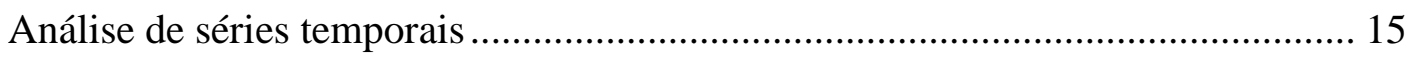

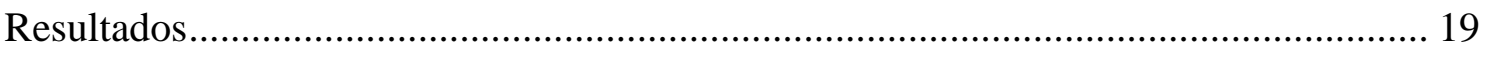

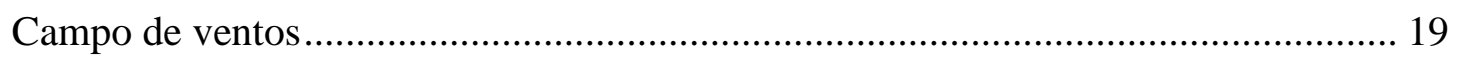

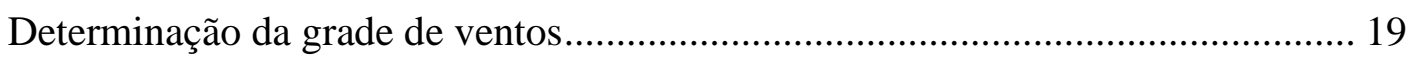

Ventos paralelos e perpendiculares à costa ...................................................... 21

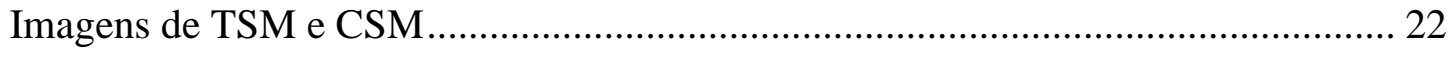

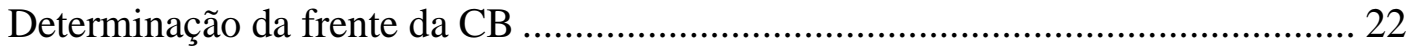

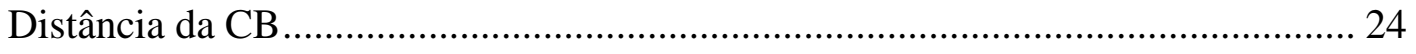

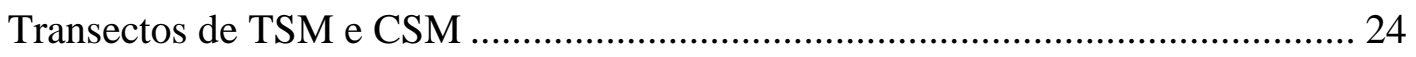

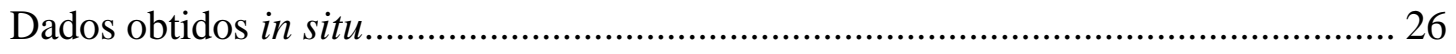

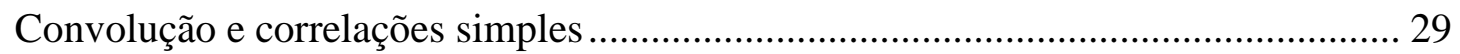

Correlações entre os ventos e as variáveis obtidas in situ..................................... 29

Correlações entre distância da CB e as variáveis obtidas in situ .......................... 35

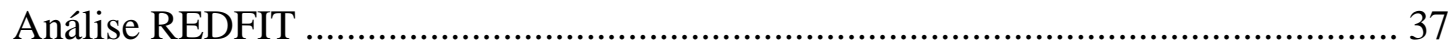

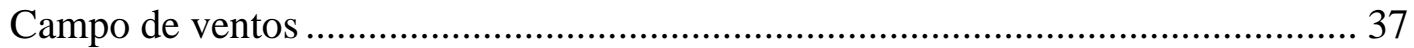

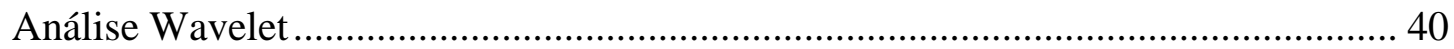

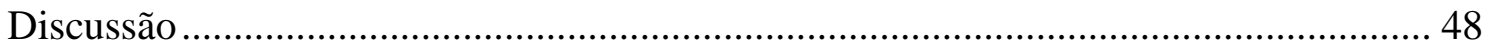

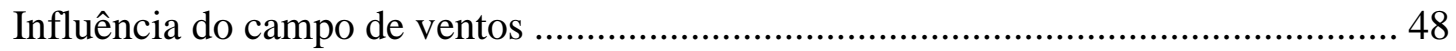


Influência do meandramento da CB 52

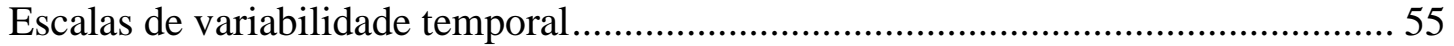

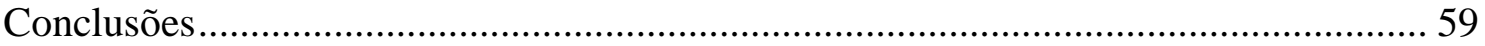

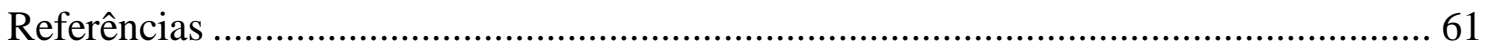

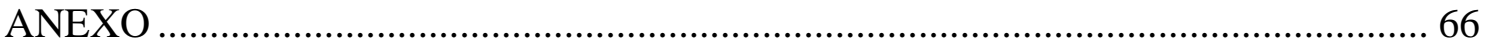





\section{Resumo}

O presente trabalho teve por objetivo estudar o efeito do campo de ventos e do meandramento da Corrente do Brasil nas variabilidades hidrográfica e bioquímica ao largo da costa norte do Estado de São Paulo. Foram utilizados dados de temperatura, nutrientes e clorofila- $a$ obtidos in situ mensalmente ao largo de Ubatuba entre dezembro de 2004 a abril de 2014, dados do campo de ventos do pacote Blended Sea Winds (NCDC/NOAA), além de Temperatura da Superfície do Mar e Clorofila- $a$ da Superfície do Mar do sensor MODIS/AQUA. Os dados obtidos mostraram que na primavera o vento paralelo teve forte correlação com a temperatura em toda coluna de água, evidenciando a importância da intrusão remota nesta estação. No verão as altas correlações com o nitrato indicam a dominância de intrusão local. A correlação com a distância da Corrente do Brasil foi significativa com a clorofila- $a$, o nitrato e fosfato. Os resultados permitem inferir que o vento é o principal fator que determina a variabilidade hidrográfica e bioquímica na área de estudo, e que o meandramento da Corrente do Brasil teria papel secundário na dinâmica da plataforma continental interna.

Palavras-chave: séries temporais, campo de ventos, meandramento da Corrente do Brasil, ACAS, intrusão remota, Plataforma Continental Sudeste do Brasil, Wavelet, MODIS 


\begin{abstract}
The main goal of this work is to evaluate the effect of the wind field and Brazil Current meandering on hydrographic and biochemical variability off northern coast of Sao Paulo, Brazil. The dataset used were comprised of monthly samples of temperature, chlorophyll- $a$ and nutrients acquired in situ in Ubatuba from December 2004 to April 2014, wind field derived from NCDC/NOAA Blended Sea Winds package, as well as sea surface temperature and sea surface chlorophyll remotely sensed by MODIS aboard Acqua satellite. Data analysis reveal a strong correlation of along-shore wind component with the water temperature in all depths at spring, pointing out the importance of remote intrusion and advection of South Atlantic Central Water at the sampling site. During summer, however, high correlation of said wind component with nitrate concentration show dominance of local intrusion processes. The distance between the sampling station and the Brazil Current front correlated significantly with chlorophyll- $a$, nitrate and phosphate. These results suggest that the wind is the main driver of biochemical and hydrographic variability at the study area, while the Brazil Current front meandering plays a secondary role in the internal shelf dynamics.
\end{abstract}

Keywords: time series, wind field, Brazil Current meandering, ACAS, remote intrusion, southern Brazilian continental shelf, Wavelet, MODIS 


\section{Lista de Figuras}

Figura 1: Plataforma continental da região Sudeste do Brasil, mostrando o ponto de coleta da série temporal realizada no período de dezembro de 2004 a abril de 2014 ..... 6

Figura 2: Transectos extraídos das imagens de satélite de temperatura da superfície do mar e clorofila. T1 liga o ponto de coleta ao Estado de Santa Catarina, T2 é aproximadamente ortogonal às isóbatas em direção ao largo (offshore) e o T3 liga o ponto de coleta ao Estado do Rio de Janeiro.

Figura 3: Imagem ilustrativa do pacote de onda Morlet.

Figura 4: Mapa de correlação dos ventos zonal (esquerda) e meridional (direita) com a temperatura de fundo. O retângulo indica a área da grade de ventos selecionada para realização das análises.

Figura 5: Grade selecionada para elaboração da série temporal dos ventos entre as regiões de Cabo Frio (RJ) e Cabo de Santa Marta (SC), no período de dezembro de 2004 a abril de 2014.

Figura 6: Direção, intensidade e frequência dos ventos, da área selecionada na figura 5, correspondentes ao período de dezembro de 2004 a abril de 2014. A intensidade é dada pela escala de cores.

Figura 7: Série temporal da grade de ventos selecionada na figura 5, correspondente ao período de dezembro de 2004 a abril de 2014, aplicando-se um filtro de 30 dias.

Figura 8: Mosaico de duas imagens de TSM (direita) e clorofila (esquerda) dos dias 25 e 27 de janeiro de 2013. A posição do transecto coletado pelo CARBOM III é dada pela linha tracejada e as estações são dadas pelos círculos amarelos.

Figura 9: Transecto de salinidade coletado entre os dias 25 e 30 de janeiro de 2013. As linhas tracejadas são as posições das estações de coleta. Os dados foram interpolados lateralmente.

Figura 10: Á esquerda os transectos de TSM (linha vermelha) e CSM (linha verde) normalizados e à direita a segunda derivada do transecto de CSM. Os rótulos indicam a posição da frente da $\mathrm{CB}$ e a respectiva distância da costa.

Figura 11: Distância entre a frente da CB e o ponto de coleta ao largo de Ubatuba, Estado de São Paulo no período compreendido entre dezembro de 2004 a abril de 2014.

Figura 12: Série temporal dos transectos de TSM obtidos nos dias de coleta realizadas entre dezembro de 2004 a abril de 2014. De cima para baixo: T1, T2 e T3 25 
Figura 13: Série temporal dos transectos de CSM obtidos a partir de dados do Satelite MODIS/AQUA. De cima para baixo observa-se o T1, T2 e T3.

Figura 14: Série temporal de temperatura obtida in situ ao largo de Ubatuba, Estado de São Paulo, no período de dezembro de 2004 a abril de 2014.

Figura 15: Série temporal dos nutrientes obtidos in situ ao largo de Ubatuba, Estado de São Paulo, no período compreendido entre dezembro de 2004 e abril de 2014. 28

Figura 16: Série temporal de clorofila-a obtida in situ ao largo de Ubatuba, Estado de São Paulo, no período compreendido entre dezembro de 2004 e abril de 2014.

Figura 17: Convolução entre os ventos paralelo (gráfico superior) e perpendicular (gráfico inferior) e a temperatura de fundo. A linha tracejada vermelha indica o valor crítico $(\mathrm{p}=0,05 ; \mathrm{N}=110)$.

Figura 18: Dispersão dos valores de temperatura de fundo e o vento paralelo, com filtro de 50 dias e atraso de 15 dias. A linha preta representa a reta de regressão linear considerando a série completa e o espaço entre as linhas vermelhas o intervalo que contém $50 \%$ dos pontos.

Figura 19: Correlação entre os ventos paralelo (gráfico superior) e perpendicular (gráfico inferior) com a temperatura registrada em diferentes profundidades. As linhas tracejadas vermelhas finas indicam os valores críticos do coeficiente de correlação para $\mathrm{N}=110$ (total) e as grossas para $\mathrm{N}=23$ (por estação), com $\mathrm{p}=0,05$.

Figura 20: Correlação entre vento paralelo (esquerda) e o perpendicular (direita) com as variáveis obtidas in situ por profundidade. As linhas tracejadas vermelhas finas indicam os valores críticos do coeficiente de correlação para $\mathrm{N}=110$ (total) e as grossas para $\mathrm{N}$ $=23$ (por estação), com $\mathrm{p}=0,05$.

Figura 21: Correlação entre vento paralelo (esquerda) e o perpendicular (direita) com as variáveis obtidas in situ por profundidade. As linhas tracejadas vermelhas finas indicam os valores críticos do coeficiente de correlação para $\mathrm{N}=110$ (total) e as grossas para $\mathrm{N}$ $=23$ (por estação), com $\mathrm{p}=0,05$.

Figura 22: Correlação entre a distância da CB com as variáveis obtidas in situ por profundidade. As linhas tracejadas vermelhas finas indicam os valores críticos do coeficiente de correlação para $\mathrm{N}=110$ (total) e as grossas para $\mathrm{N}=23$ (por estação), com $\mathrm{p}=0,05$.

Figura 23: Correlação entre a distância da CB com as variáveis obtidas in situ em diferentes profundidades, ao largo de Ubatuba, Estado de São Paulo. As linhas tracejadas vermelhas finas indicam os valores críticos do coeficiente de correlação para $\mathrm{N}=110$ (total) e as grossas para $\mathrm{N}=23$ (por estação), com $\mathrm{p}=0,05$.

Figura 24: Diagrama de densidade espectral dos ventos paralelo (gráfico superior) e perpendicular gráfico inferior). As linhas tracejadas indicam os níveis de significância $(\mathrm{p}=0,05)$. Os períodos significativos são indicados 
Figura 25: Diagrama de densidade espectral da distância da CB. A linha tracejada indica o nível de significância $(\mathrm{p}=0,05)$. Os períodos significativos são indicados. 38

Figura 26: Diagrama de densidade espectral das temperaturas de superfície (azul) e fundo (preto). As linhas tracejadas indicam os níveis de significância $(\mathrm{p}=0,05)$. Os períodos significativos são indicados.

Figura 27: Diagrama de densidade espectral do nitrato (superior) e do fosfato (inferior). As linhas tracejadas indicam os níveis de significância $(\mathrm{p}=0,05)$. Os períodos significativos são indicado..

Figura 28: Diagrama de densidade espectral da série de clorofila-a obtida in situ ao largo de Ubatuba, Estado de São Paulo. A linha tracejada indica o nível de significância $(\mathrm{p}=0,05)$. Os períodos significativos são indicados. 40

Figura 29: Diagrama da TWC dos ventos paralelo (esquerda) e perpendicular (direita) à costa obtidos no período de dezembro de 2004 e abril de 2014 ao largo de Ubatuba, Estado de São Paulo. A área interna ao cone esbranquiçado delimita a região de significância. Os contornos indicam os valores significativos $(\mathrm{p}<0,05)$.

Figura 30: Diagrama da TWC da distância da CB referente ao período de dezembro de 2004 a abril de 2014, ao largo de Ubatuba, Estado de São Paulo. A área interna ao cone esbranquiçado delimita a região de significância. Os contornos indicam os valores significativos $(\mathrm{p}<0,05)$.

Figura 31: Diagrama da TWC da temperatura (direita) e nitrato integrado (esquerda) coletados in situ no período de dezembro de 2004 a abril de 2014, ao largo de Ubatuba, Estado de São Paulo. A área interna ao cone esbranquiçado delimita a região de significância. Os contornos indicam os valores significativos $(\mathrm{p}<0,05)$.

Figura 32: Diagrama da TWC do fosfato integrado (esquerda) e clorofila-a integrada (direita) coletados in situ no período de dezembro de 2004 a abril de 2014, ao largo de Ubatuba, Estado de São Paulo. A área interna ao cone esbranquiçado delimita a região de significância. Os contornos indicam os valores significativos $(\mathrm{p}<0,05)$.

Figura 33: Diagrama da TWX (esquerda) e WC (direita) do vento paralelo à costa e temperatura obtida in situ ao largo de Ubatuba, Estado de São Paulo, no período compreendido entre 2004 a 2014. A área interna ao cone esbranquiçado delimita a região de significância. Os contornos indicam os valores significativos $(p<0,05)$.

Figura 34: Diagrama da TWX (esquerda) e WC (direita) do vento paralelo à costa e nitrato integrado obtido in situ ao largo de Ubatuba, Estado de São Paulo, no período compreendido entre 2004 a 2014. A área interna ao cone esbranquiçado delimita a região de significância. Os contornos indicam os valores significativos $(p<0,05)$.

Figura 35: Diagrama da TWX (esquerda) e WC (direita) do vento paralelo à costa e o fosfato integrado obtido in situ ao largo de Ubatuba, Estado de São Paulo, no período compreendido entre 2004 a 2014. A área interna ao cone esbranquiçado delimita a região de significância. Os contornos indicam os valores significativos $(\mathrm{p}<0,05)$. 
Figura 36: Diagrama da TWX (esquerda) e WC (direita) do vento paralelo à costa e a clorofila-a integrada obtida in situ ao largo de Ubatuba, Estado de São Paulo, no período compreendido entre 2004 a 2014. A área interna ao cone esbranquiçado delimita a região de significância. Os contornos indicam os valores significativos $(\mathrm{p}<0,05)$.

Figura 37: Diagrama da TWX (esquerda) e WC (direita) da distância da CB e da temperatura obtida in situ ao largo de Ubatuba, Estado de São Paulo, no período compreendido entre 2004 a 2014. A área interna ao cone esbranquiçado delimita a região de significância. Os contornos indicam os valores significativos $(\mathrm{p}<0,05)$........ 46

Figura 38: Diagrama da TWX (esquerda) e WC (direita) da distância da CB e nitrato obtido in situ ao largo de Ubatuba, Estado de São Paulo, no período compreendido entre 2004 a 2014. A área interna ao cone esbranquiçado delimita a região de significância. Os contornos indicam os valores significativos $(\mathrm{p}<0,05)$.

Figura 39: Diagrama da TWX (esquerda) e WC (direita) da distância da CB e fosfato obtido in situ ao largo de Ubatuba, Estado de São Paulo, no período compreendido entre 2004 a 2014. A área interna ao cone esbranquiçado delimita a região de significância.

Os contornos indicam os valores significativos $(\mathrm{p}<0,05)$.

Figura 40: Diagrama da TWX (esquerda) e WC (direita) da distância da CB e clorofila-a obtida in situ ao largo de Ubatuba, Estado de São Paulo, no período compreendido entre 2004 a 2014. A área interna ao cone esbranquiçado delimita a região de significância. Os contornos indicam os valores significativos $(\mathrm{p}<0,05)$.

Figura 41: Imagem de TSM de 21 de julho de 2007. Nota-se o deslocamento da Frente Subtropical do Rio da Prata sobre a PCSE.

Figura 42: Imagem de CSM de 28 de janeiro de 2010. Nota-se a presença de um vórtice anticiclônico ao largo da PCSE.

Figura 43: Imagem de altimatria de 28 de janeiro de 2010. Nota-se a presença vórtices ciclônicos e anticiclônico ao largo da PCSE.

Figura 44: Diagrama dos períodos significativos da série de dezembro de 2004 a abril de 2014 de ventos, distância da CB e dados obtidos in situ. As cores relacionam as variáveis aos períodos significativos e a abcissa indica o período. 


\section{Lista de Tabelas}

Tabela 1: Correlação simples entre os ventos, distância da CB, temperatura de fundo e as variáveis bioquímicas integradas na coluna de água. Os valores significativos estão destacados em negrito ( $\mathrm{p}<0,05 ; \mathrm{N}=110$ ). Valor-p (azul) e coeficiente de correlação (preto).

Tabela 2: Diferença, em dias, entre as datas de coleta e as datas das imagens de satélite selecionadas para compor o mosaico que representar o dia de coleta. 


\section{Introdução}

As plataformas continentais representam menos de $10 \%$ da área total dos oceanos, mas são responsáveis por grande parte da dinâmica biogeoquímica que ocorre no ambiente marinho. A soma da produção de matéria orgânica dos oceanos foi estimada em 45 a 60 Gt por ano (Longhurst et al., 1995; Behrenfeld et al., 2005), enquanto a produção das plataformas continentais pode atingir $11 \mathrm{Gt}$ por ano (Jahnke, 2010). Esta diferença de produtividade se deve ao fato das plataformas serem ambientes onde ocorre grande dissipação de energia mecânica proveniente de ondas de gravidade, marés e vento, além dos aportes da drenagem continental e atmosféricos. Nestes ambientes, os encontros de massas de água são recorrentes, favorecendo processos de convergência e de mistura, que resultam em regiões extremamente produtivas do ponto de vista biológico (Olson and Backus, 1985). A complexidade destes sistemas costeiros é ainda maior nos contornos oeste dos oceanos, onde a estratificação e ressurgências intermitentes estabelecem gradientes físicos conspícuos, tanto verticais como horizontais, ampliando o espectro de processos biogeoquímicos.

Em geral, a região costeira tem papel fundamental na bomba biológica. Há estimativas de que $47 \%$ da exportação global do carbono para o leito marinho ocorra em plataformas continentais (Jahnke, 2010), o que equivale a uma proporção de exportação/produção cinco vezes maior que as regiões oceânicas. Além de sua importância na manutenção da concentração do carbono na atmosfera e, consequentemente, do equilíbrio do efeito estufa, a zona costeira é extremamente produtiva do ponto de vista pesqueiro, contribuindo com cerca de $90 \%$ da pesca mundial (Pauly et al., 2002). O mercado da pesca global gera lucro de 8 bilhões de dólares por ano para empresas e emprega 170 milhões de pessoas de forma direta ou indireta (World Bank e FAO, 2009). Se considerarmos as movimentações geradas pela pesca no mundo, a contribuição deste setor para a economia é de aproximadamente de 235 bilhões de dólares por ano (Dyck and Sumaila, 2010). Assim, a pesca na zona costeira é vital para a sócio economia mundial.

Levando-se em consideração que aproximadamente $23 \%$ população mundial vive nos primeiros $100 \mathrm{~km}$ da costa (Nicholls e Small, 2002), é possível inferir que o bioma costeiro está sujeito a impactos antropogênicos significativos. Os impactos podem ser observados em escala local como poluição industrial e doméstica, resultando em 
eutrofização, perda da qualidade da água, diminuição da riqueza de espécies, e consequências negativas para a economia local. Em escala regional, os impactos ficam evidentes no aumento da vulnerabilidade de ecossistemas através da conectividade de áreas impactadas, enquanto que em escala global são observadas mudanças no balanço de radiação, aumento do nível médio do mar, bem como maior frequência e intensidade de tempestades em regiões propensas (Turner et al. 1996). Esses efeitos aumentam o risco à saúde e economia das populações que vivem ou se beneficiam da zona costeira, especialmente nos países em desenvolvimento, cujas políticas e investimentos em atividades sustentáveis muitas vezes não são suficientes para mitigar os impactos gerados pela ação antrópica. Para orientar estas políticas e atividades é necessário diferenciar os impactos provenientes da atividade humana dos provocados pelo próprio ambiente.

A proximidade da costa torna difícil a previsão do comportamento e o estabelecimento de padrões dos processos biogeoquímicos, pois interações com a margem e o substrato tornam-se cada vez mais intensas, aumentando a complexidade destes sistemas. Além disso, a dinâmica costeira e seus processos naturais se alteram em função do aumento da pressão antrópica, principalmente nas proximidades da costa. Séries temporais oceanográficas são imprescindíveis para saber qual a resiliência do ecossistema costeiro frente aos impactos antropogênicos constantes em diversas escalas de tempo (Karl, 2010). Registros de longa duração permitem separar os diversos sinais do ruído dos dados (Overland et al., 2006), estabelecer padrões e explorar relações de causa e efeito. Os resultados destes exercícios são fundamentais para fortalecer os modelos teóricos, testados através dos modelos numéricos, a fim de compreender como o ambiente é estruturado.

Estudos das funções dos organismos no ecossistema e suas interações bioquímicas, baseados no monitoramento da distribuição dos microrganismos fotossintetizantes, são uma forma tangível de compreender a dinâmica do ecossistema. Isto por que é impraticável quantificar a distribuição da biomassa e suas relações em todos os níveis tróficos (Muller et al., 2014). Conhecer as interações do fitoplâncton com as massas de água é fundamental para compreender como ocorrem os ciclos biogeoquímicos, uma vez que os produtores primários são o elo entre o ambiente e a biota (Sarmiento e Gruber, 2006). Estes organismos são extremamente sensíveis às alterações que ocorrem no ecossistema, seja por controle "top-down" ou "botton-up" (Power, 1992).

A duração, a intensidade e o tipo de produtor primário em desenvolvimento são essenciais para determinar o recrutamento nos níveis tróficos superiores (Platt et al., 
2003). A distribuição do fitoplâncton depende essencialmente dos mecanismos físicos de circulação e turbulência das massas de água (Therriault et al., 1978). Grande parte da variabilidade da concentração de clorofila- $a$ e da composição fitoplâncton está relacionada à circulação oceânica e aos processos físicos de mesoescala (Simpson e Shapler, 2012). O transporte de parcelas de água ricas em nutrientes para a zona eufótica é o processo chave para o desenvolvimento do fitoplâncton. Em condições onde a radiação solar é suficiente e a camada de mistura coincide com a zona eufótica, processos físicos transientes, como a ressurgência costeira provocada pelo transporte de Ekman ou meandramentos causados por instabilidades das correntes, podem ser responsáveis pelo transporte de nutrientes para camada de mistura. $\mathrm{O}$ resultado é o aumento da biomassa fitoplanctônica, que favorece a transferência de energia para os níveis tróficos superiores e o fluxo de carbono para o leito marinho.

Ressurgências costeiras acontecem quando ventos paralelos à costa aceleram correntes superficiais e, após o período inercial (rotação da Terra), é estabelecido um fluxo perpendicular à costa (Simpson e Sharples, 2012). Se o transporte superficial, denominado camada de Ekman, tiver sentido ao largo, haverá divergência unilateral do campo de velocidade das correntes, gerando movimentos ascendentes próximo à costa. Por continuidade é criado um fluxo de retorno no fundo, transportando águas ricas em nutrientes em direção à costa e para a superfície. Este processo ocorre geralmente após dois períodos inercias. Se a picnoclina aflora na superfície, o fenômeno é caracterizado como ressurgência, caso contrário, será um evento de intrusão. Se houver convergência superficial, as águas da superfície preencherão a coluna de água na proximidade da costa, deslocando as águas mais ricas em nutrientes para o largo.

A estratificação também é um fator que está relacionado à resposta do transporte de Ekman ao vento. Em regiões estratificadas, as correntes geradas pelo transporte de Ekman são mais intensas e diminuem nas proximidades da costa, onde os movimentos verticais ficam mais fortes $(<10 \mathrm{~km})$. Na ausência de estratificação, o transporte de Ekman é menos intenso e os movimentos de subsidência e ressurgência ocorrem principalmente na quebra da plataforma (Lentz, 2001). Se considerarmos o verão de latitudes médias, onde há estratificação na coluna de água, o estresse do vento está fortemente correlacionado à temperatura de fundo na plataforma interna, enquanto no inverno, na ausência de estratificação, esta correlação fica restrita à quebra da plataforma.

Em geral, o vento atua paralelo a costa, a divergência ou convergência criada pelo transporte de Ekman origina um gradiente de pressão perpendicular à costa. A aceleração 
decorrente deste gradiente será equilibrada pela força de Coriolis e originará uma corrente geostrófica ao longo da costa, na mesma direção do vento. Esta corrente se estende por toda a coluna de água, criando atrito com o fundo, que resulta no transporte de Ekman de fundo, análogo ao transporte de Ekman gerado pelo cisalhamento do vento, porém em sentido oposto. Após o período de ajuste inicial, o transporte de Ekman de superfície é equilibrado pelo transporte de Ekman de fundo. Em condições de ressurgência, não há variações significativas deste balanço próximo à frente de superfície (região de elevado gradiente horizontal). No entanto, em condições de subsidência o estresse com o fundo pode ser duas vezes maior que o de superfície na região interna da frente, que resulta na diminuição da velocidade do fluxo ao longo da costa (Austin e Lentz, 2002). Assim, o transporte barotrópico de água ressurgida ao longo da costa gera correntes mais intensas que o transporte barotrópico de água convergida na costa, para um campo de ventos de mesma duração e intensidade.

Ressurgências de talude induzida pelo meandramentos e vórtices ciclônicos também são um importante fator para a fertilização de ecossistemas que estão sob influência das correntes de contorno oeste, principalmente na quebra da plataforma continental (Lee et al., 1981; Yoder et al., 1981; Sasaki et al.,1985; Kimura et al., 1997). Porém, como estas feições são características de processos de mesoescala $(\sim 10 \mathrm{~km}$ a $\sim 100 \mathrm{~km}$ ), os meandros e vórtices são importantes para a troca de massa e energia entre a plataforma e as regiões oceânicas. Lee e Pietrafesa (1987) identificaram três importantes processos para que ocorra uma ressurgência plena na plataforma interna: (1) a posição da frente da corrente de contorno plataforma externa, (2) presença de meandros ciclônicos e (3) ventos favoráveis para a ressurgência. Hamilton (1987) verificou que o processo (1), isolado ou em combinação com o processo (2), é responsável pelo início da intrusão na plataforma. Porém, ventos favoráveis para a ressurgência (3) são imprescindíveis para que ocorra uma intrusão que atinja a plataforma interna. De acordo com Campos et al., (2000) o meandramento ciclônico é responsável por promover o bombeamento de águas profundas para regiões mais rasas da plataforma, o qual aliado aos ventos favoráveis, pode amplificar o processo de ressurgência.

A zona costeira do Estado de São Paulo tem características morfológicas e hidrológicas ideais para estudar os efeitos do campo de ventos e meandramentos nos processos de desenvolvimento do fitoplâncton. Um exemplo constitui a ausência de grandes rios que reduz os efeitos da drenagem continental e antropogênicos na eutrofização costeira e, consequentemente, nos processos biogeoquímicos naturais. A 
exposição a descargas de águas menos salinas ocorre esporadicamente, através da pluma do Prata (Piola et al., 2000), que eventualmente atinge a Ilha de São Sebastião durante o inverno. A amplitude de maré reduzida também simplifica os processos de mistura e circulação ao longo da plataforma, tornando as condições mais estáveis em escalas de tempo submaregráficas.

Na região norte da costa do Estado de São Paulo, o vento é o principal fator que determina a variabilidade hidrográfica e biológica. Apesar da distância, o meandramento da CB também afeta esta variabilidade. Os processos hidrodinâmicos e bioquímicos ocorrem em diversas escalas de tempo e são aproximadamente cíclicos ou determinísticos. Portanto, é possível determinar padrões nos dados oceanográficos e atmosféricos observacionais, bem como identificar os mecanismos físicos e suas escalas temporais mais importantes para o desenvolvimento do fitoplâncton nesta região.

\section{Objetivos}

\section{Principal}

O objetivo do presente trabalho foi estudar o efeito do campo de ventos e do meandramento da Corrente do Brasil sobre a variabilidade hidrográfica e bioquímica ao largo da região norte da costa do Estado de São Paulo, bem como os padrões e processos cíclicos envolvidos nas variações da temperatura, na concentração de nutrientes e biomassa fitoplanctônica.

\section{Específicos}

1. Determinar o tamanho e a posição da grade do campo de ventos que melhor se correlaciona com a temperatura de fundo;

2. Parametrizar o efeito do meandramento da Corrente do Brasil;

3. Testar as correlações entre a grade do campo de ventos, meandramento da Corrente do Brasil e as variáveis bioquímicas;

4. Identificar ciclos e escalas temporais de variação comuns nas séries de dados obtidos in situ e remotamente. 


\section{Materiais e Métodos}

\section{Área de Estudo}

O ponto de coleta dos dados in situ está localizado no litoral norte do Estado de São Paulo, Plataforma Continental da Região Sudeste do Brasil (PCSE). Porém, como um dos objetivos do estudo foi identificar a área de influência dos ventos, a região compreendida entre Cabo Frio (RJ) e Cabo de Santa Marta (SC) também foi considerada (Figura 1).

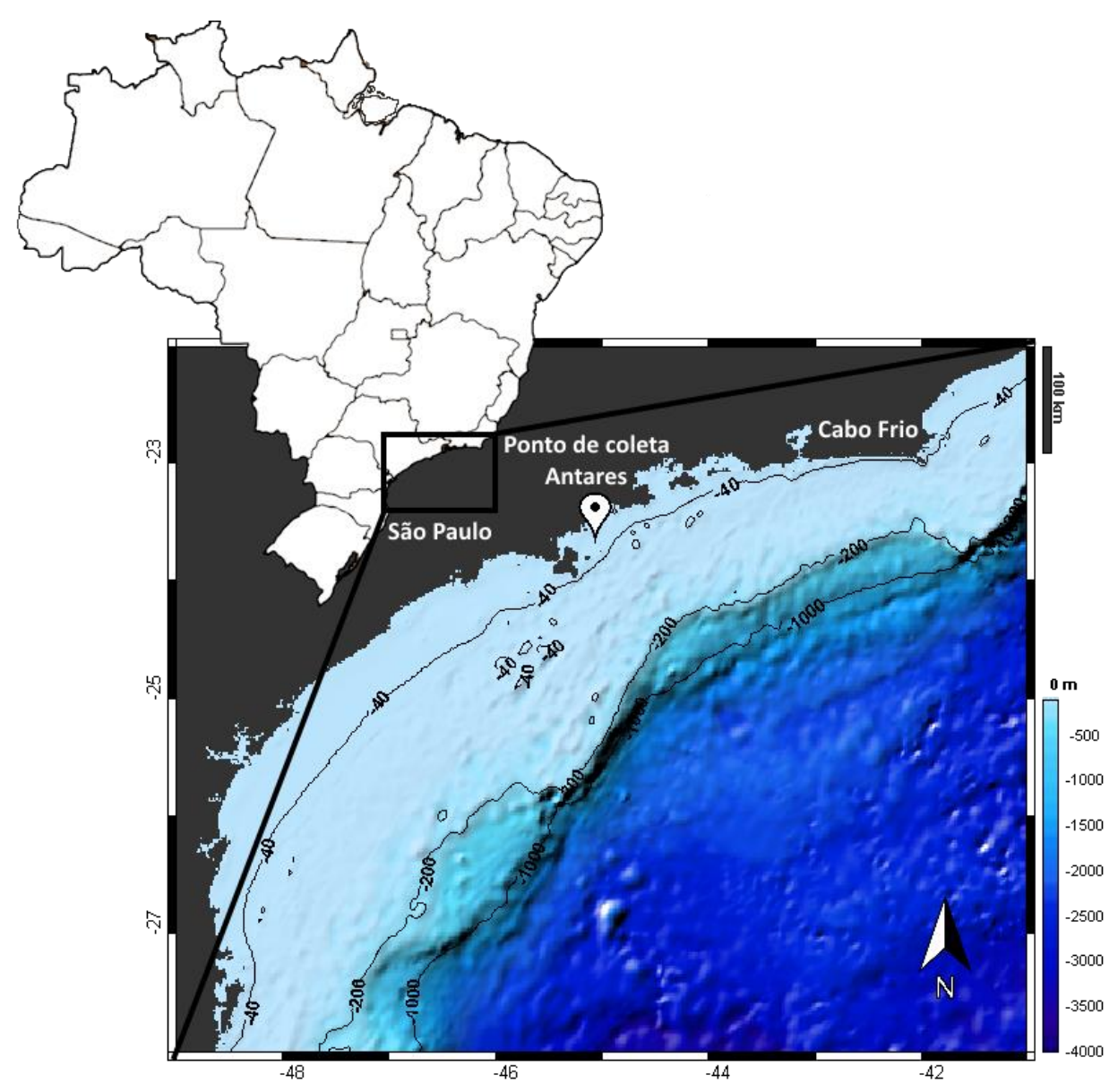

Figura 1: Plataforma continental da região Sudeste do Brasil, mostrando o ponto de coleta da série temporal realizada no período de dezembro de 2004 a abril de 2014.

De acordo com Mahiques (2010), a largura da PCSE varia entre os $70 \mathrm{~km}$ no Rio de Janeiro e $230 \mathrm{~km}$ na região central do Estado de São Paulo, enquanto a quebra da plataforma é de 120 a $180 \mathrm{~m}$, respectivamente. Com relação à declividade média dessas duas regiões, no Rio de Janeiro é de 1:600, enquanto na região média do Estado de São Paulo atinge 1:1300. A orientação da linha de costa é aproximadamente sudoeste- 
nordeste, que coincide com a direção média dos ventos ao longo do ano (Satyamurty et al., 1998).

As principais forçantes hidrográficas desta região são os ventos locais e remotos, marés, gradientes de pressão baroclínico e a Corrente do Brasil (Castro et al., 2006). Ventos de NE provenientes da Alta Subtropical do Atlântico Sul (ASAS) são característicos de verão. Estes ventos, quando atuam paralelamente à linha de costa empurram as águas superficiais ao largo, através do transporte de Ekman, promovendo a estratificação da coluna de água devido ao preenchimento das regiões mais profundas pela Água Central do Atlântico Sul (ACAS), massa de água rica em nutrientes. Este fenômeno pode ser denominado intrusão local, uma vez que a ACAS penetra perpendicularmente às isóbatas. A intrusão local tem como via primária a região ao largo de Cabo Frio, recorrente no verão, inverno e primavera, sendo a região ao largo de Ubatuba a via secundária, recorrente na primavera (Cerda e Castro, 2014). Ao largo de Santa Catarina, a intrusão local de ACAS avança em direção à costa 60 km em 72 dias, atingindo a velocidade média de $1 \mathrm{~cm} / \mathrm{s}$ (Brandini et al., 2014).

Além dessas intrusões locais na plataforma, a ACAS pode ressurgir em regiões distantes e ser advectada ao longo da plataforma, obedecendo ao balanço geostrófico forçado pelo vento (Amor, 2004). Este tipo de intrusão, chamada remota, pode ser observado no verão, inverno e primavera (Cerda e Castro, 2014). As imagens de satélite de Temperatura da Superfície do Mar (TSM) evidenciam que no verão, 10 dias após um fenômeno de ressurgência em Cabo Frio, a ACAS percorreu 300 a 400 km, atingindo a Ilha de São Sebastião (Lorenzetti e Gaeta, 1996).

$\mathrm{Na}$ área de estudo, embora as frentes frias sejam comuns em todas as estações do ano, ocorrem em média duas a três passagens de sistemas frontais em fevereiro e cinco a seis em outubro (Oliveira, 1986). Estes sistemas representam condições desfavoráveis para sustentar a intrusão da ACAS e são responsáveis pela intensa mistura na coluna de água, favorecendo a entrada de nutrientes na zona eufótica devido a remobilização do substrato rico em compostos nitrogenados. Assim, tanto os ventos de NE, característicos de verão, como a passagem de frentes frias, recorrentes no inverno, podem estar relacionados ao aumento da produtividade primária (Gaeta, 1999; Oliveira, 2009). Os efeitos da frente sobre a hidrodinâmica da plataforma continental, após sua passagem, podem durar cerca de uma dia e meio (Stech e Lorenzzetti, 1991). As correntes podem se reverter completamente, especialmente a componente ao longo da costa. Estes distúrbios assumem um equilíbrio quase-geostrófico e se movem juntamente com o sistema frontal 
atmosférico, ou seja, rumo nordeste. Como o período da ocorrência da frente é próximo ao de oscilação inercial da Terra, as frentes frias podem amplificar as ondas de oscilação inercial, resultando em grande mistura da coluna de água. Nas regiões internas da plataforma, onde a interação com a topografia afeta fortemente o balanço geostrófico, o balanço dominante ocorre entre o estresse com o vento e o estresse com o fundo, gerando correntes na mesma direção do vento com quase nenhum atraso. Já nas regiões externas da plataforma, há uma declinação de $90^{\circ}$ entre o estresse do vento e as correntes superficiais, indicando o predomínio do transporte de Ekman (Stech e Lorenzzetti, 1991).

A Corrente do Brasil (CB) também pode facilitar o processo de afloramento da ACAS em regiões mais rasas (Campos et al., 1995). A ocorrência de meandros pode ser atribuída à quebra da linha de costa e ao gradiente de topografia de fundo nas proximidades de Cabo Frio. Como CB flui para o sul ao longo da costa, transportando Água Tropical (AT) na superfície e ACAS em níveis picnoclínicos, quando há mudança na orientação da linha de costa nas proximidades de Cabo Frio, por inércia, o fluxo tende a se dirigir para águas mais profundas. Por conservação de vorticidade, a corrente meandra ciclonicamente e em seguida anticiclonicamente, comportando-se como uma onda de Rossby topográfica dentro da Bacia de Santos. Os movimentos ciclônicos na quebra da plataforma tendem a inclinar as isopicnais em direção à superfície, formando um domo de água fria. Enquanto o meandro ciclônico ou vórtice ciclônico, caso haja desprendimento desta feição do eixo da $\mathrm{CB}$, se desloca para sudoeste, seu núcleo é continuamente renovado com águas que ressurgem na parte anterior e afundam na parte posterior. Como sua circulação se dá no sentido horário, a água ressurgida na parte anterior tende a ser advectada para regiões mais rasas (Campos et al., 1995).

$\mathrm{Na}$ Bacia de Campos, a maior parte dos eventos de ressurgência ocorrem na presença de meandros ciclônicos de propagação quase-nula (Paloczy et al., 2013). Nos casos em que ocorre ressurgência costeira, o trabalho realizado pelo vento é cerca de $30 \%$ menor que nos casos em que não há meandramento. Por outro lado, na hipótese da ausência da $\mathrm{CB}$, com a profundidade da picnoclina igual àquela encontrada nas regiões centrais do giro subtropical, seriam necessários de 35 a 45 dias de ventos favoráveis para gerar a ressurgência costeira. Esta escala de tempo é uma ordem de grandeza maior que a observada. Evidenciando-se, assim, a importância dos meandramentos da CB como desencadeadores dos eventos de ressurgência costeira provocados pelo vento, pois favorecem a presença da ACAS na região da quebra da plataforma (Campos, 1995). 
Análogo aos meandros, vórtices podem apresentar núcleos de água fria ou quente, que definirão seu comportamento ciclônico ou anticiclônico, respectivamente. A presença de um núcleo de água fria pode transportar nutrientes para camadas superficiais, possibilitando o desenvolvimento da biomassa fitoplanctônica em regiões onde não haveria disponibilidade de nutrientes. No entanto, quando vórtices ciclônicos chegam próximos ao fundo, pode ocorrer o transporte de Ekman de fundo em direção ao largo, retardando a penetração da ACAS sobre a PCSE.

Em regiões de plataforma, as marés têm papel no bombeamento de nutrientes para a zona fótica (New e Pingree, 1990). Essa disponibilidade de nutrientes deve-se à elevação da nutriclina provocada pelas ondas internas e pela quebra da estratificação, gerada por frentes de mistura de marés e/ou quebra de ondas internas na plataforma (Demers et al., 1986; Brandini et al., 2014), sendo a escala temporal de algumas horas (Guinder et al., 2009). Na PCSE as correntes de marés são menos intensas que as geradas pelos ventos, sendo sua contribuição para as correntes totais cerca de $10 \%$ na componente paralela à costa e 45\% da variância perpendicular à costa (Castro, 1996; Dottori e Castro, 2009).

Na PCSE o desenvolvimento do fitoplâncton é limitado essencialmente pelo nitrato, cujo principal mecanismo de introdução é a intrusão ou afloramento sazonal da ACAS (Aidar et al., 1993; Castro et al., 2006). O enriquecimento da camada de mistura pela turbulência que envolve a ACAS na zona eufótica, pode levar horas a dias, influenciando a composição e a abundância das comunidades fitoplanctônicas (Saldanha, 1993; Saldanha-Corrêa,1999). Trabalhos pretéritos descrevem a dominância de diatomáceas na plataforma interna (Brandini, 1988a; Brandini et al., 1989; Fernandes et al., 1999; Fernandes e Brandini, 2004), microflagelados nas frentes de mistura de maré no limite da plataforma interna e média e de picoflagelados na plataforma externa (Brandini et al., 1989). Na região interna da plataforma continental de Ubatuba, os fitoflagelados representam cerca de $94 \%$ do fitoplâncton, seguidos por diatomáceas, dinoflagelados e cocolitoforídeos (Zilmann, 1990). As diatomáceas e dinoflagelados são mais abundantes no verão e primavera, em contraposição, no inverno e no outono há um aumento de cocolitoforídeos. Embora seja aceito que a intrusão da ACAS é um processo essencial para o desenvolvimento da biota na PCSE, seu efeito sobre dinâmica do plâncton ainda é pouco compreendido (Ciotti et al., 2014).

A limitação temporária de nutrientes ou luz após florações de diatomáceas força estas populações a produzir esporos e afundar rapidamente, impedindo que sejam dispersadas ao largo pelo transporte de Ekman de superfície. Fora da zona eufótica estes 
esporos se acumulam na nutriclina, sobre a ACAS. Quando essa massa de água retorna para a costa e atinge a zona eufótica, esses esporos iniciam o seu desenvolvimento, o qual aliado à advecção de outros produtores primários, resulta no enriquecimento da plataforma interna em termo de biomassa fitoplanctônica (Brandini et al., 2014).

Na ausência de ACAS, a principal fonte de nutrientes na camada de mistura é a regeneração microbiana, que disponibiliza nutrientes provenientes da matéria orgânica dissolvida e particulada (Aidar et al., 1993; Sarmiento e Gruber 2006). A alça microbiana também contribui com a disponibilidade de nutrientes. A liberação do fosfato é produzida quando as bactérias são predadas pelos flagelados (García-Ruiz et al., 1999).

\section{Obtenção de dados}

Para elaboração do presente trabalho foram utilizados dados hidrográficos e bioquímicos da coluna de água coletados in situ, ao largo de Ubatuba, e remotos que incluem os de campo de ventos e imagens de satélite, obtidos pela internet.

\section{Obtenção de dados in situ}

O presente trabalho está inserido na Rede Antares iniciada em 2003, com a participação de vários países sul-americanos, e que tem como objetivo estudar as mudanças de longo período nos ecossistemas costeiros da América do Sul, a fim de poder distinguir a variabilidade natural da antrópica. Cada país participante colabora com observações oceanográficas in situ, com frequência constante, comparando estes dados com medidas de satélite, a fim de melhorar os algoritmos de estimativa de clorofila a partir das imagens de satélite.

No Brasil, o projeto Antares iniciou-se em dezembro de 2004 com observações mensais feitas ao largo de Ubatuba, Estado de São Paulo. As primeiras coletas (UBA 1 a 19) foram realizadas próximo à Ilha Vitória $\left(44^{\circ} 00,450^{`} \mathrm{~W}, 23^{\circ} 44,442^{`} \mathrm{~S}\right)$. Com a finalidade de melhorar a representatividade dos dados em relação à costa sudeste brasileira, o ponto de coleta foi transferido para uma região que sofre menos influência da dinâmica insular local (4458,509’W, 23³6,783'S). Assim, a elaboração do presente trabalho foi baseada em dados obtidos no período compreendido entre dezembro de 2004 e abril de 2014, perfazendo um total de 110 coletas. 


\section{Obtenção de dados hidrográficos}

A temperatura e a salinidade da coluna de água em cada estação de coleta foram obtidas utilizando-se perfiladores CTD, dos tipos: NXIC CTD (Falmounth Scientific, Inc); CTD acoplado ao Laser Optical Particle Counter $\left(\mathrm{LOPC}^{\circledR}\right)$; CTD acoplado ao Satlantic ${ }^{\circledR}$, sonda multiparametro EXO II (YSI) e CTD Seabird ${ }^{\circledR}$. Os dados do LOPC ${ }^{\circledR}$ e do Satlantic ${ }^{\circledR}$ foram tratados com os softwares fornecidos pelos respectivos fabricantes, enquanto os dados do NXIC CTD Falmounth Scientific, sonda multiparametro EXO II (YSI) e CTD Seabird ${ }^{\circledR}$ com o software Matlab $^{\circledR}$.

\section{Obtenção dos dados de Clorofila-a e Nutrientes}

Amostras de água foram obtidas, para análise de sais nutrientes (nitrato, nitrito, silicato, fosfato e amônia) e clorofila- $a$, com garrafas Niskin nas profundidades de 0,5 , 10, 25 e $38 \mathrm{~m}$. Os picos de fluorescência detectados em outras profundidades, pelo Satlantic ${ }^{\circledR}$, também foram amostrados. A água coletada foi armazenada em galões térmicos por até duas horas. Foram separadas alíquotas de água de cada amostra, em triplicata, para as análises dos nutrientes e da clorofila- $a$.

Para as análises de clorofila-a, um volume de $300 \mathrm{ml}$ de água foi filtrado utilizando-se filtros de fibra de vidro Whatman ${ }^{\circledR} \mathrm{GF} / \mathrm{F}$ com porosidade de $0,7 \mu \mathrm{m}$, os quais foram congelados a $-20^{\circ} \mathrm{C}$ para serem analisados posteriormente. A água filtrada foi armazenada em frascos de vidro âmbar para a análise de amônia e frascos de policarbonato para os demais nutrientes, sendo congelados à $-20^{\circ} \mathrm{C}$.

No laboratório do Instituto Oceanográfico da USP, a clorofila- $a$ foi extraída em 10ml de solvente (acetona 90\% +DMSO) durante $24 \mathrm{hs}$ e analisada segundo método descrito por Welschmeyer (1994), com fluorímetro turner 10 AU. Os nutrientes foram analisados com base no método de Grasshoff (1976), com espectrofotômetro Hitach® U-1100. 
Dados obtidos remotamente

\section{Campo de Vento}

O campo de vento foi obtido usando-se o pacote de dados da National Oceanic and Atmospheric Administration (NOAA)/Nacinal Climatic Data Center (NCDC) disponível na internet em <http://www.ncdc.noaa.gov/oa/rsad/air-sea/seawinds.html>, no formato netCDF. Estes dados são uma combinação de medidas de seis satélites e vários sensores, incluindo DMSP Special Sensor Microwave/Imager (SSM/I), Tropical Rainfall Measuring Mission (TRMM) Microwave Imager (TMI), Quick Scatterometer (QuickSCAT) e o Advenced Microwave Scanning Radiometer - EOS (AMSR-E).

As direções dos ventos provenientes da reanálise NCEP Reanalysis 2 (NRA-2) foram interpoladas em grades regulares de velocidade de cada conjunto de dados dos sensores. A resolução espacial foi $0,25^{\circ}$ e a temporal 6 horas na UTC/GMT 00, 06, 12 e 18Z. Os valores correspondem a ventos $10 \mathrm{~m}$ acima da superfície do mar. Selecionaram-se dados do Oceano Atlântico Sul, de $0.25-60^{\circ} \mathrm{S}$ e de $70-0.25^{\circ} \mathrm{W}$ de novembro de 2004 a dezembro de 2014. Uma das vantagens do uso deste pacote de dados é que a combinação das observações de vários satélites preenche as lacunas de dados de satélite individuais e reduz os erros aleatórios (Zhang et al., 2006).

\section{Imagens de Satélite}

Imagens diárias de temperatura da superfície do mar (TSM) e de clorofila- $a$ da superfície do mar (CSM) foram obtidas pelo sensor MODIS/AQUA, de setembro de 2004 a março de 2014, enquanto cobertura global da Terra pelo satélite AQUA a cada dois dias. Foram selecionadas imagens que interceptassem área de $22,5^{\circ}-28^{\circ} \mathrm{S}$ e de $49-41^{\circ} \mathrm{W}$.

Foi escolhido o Nivel-2 de processamento disponível no formato NetCDF4. Para este nível de processamento, a resolução espacial é de $1 \mathrm{~km}$. Com a finalidade de garantir a máxima coerência com o produto CSM, selecionou-se o produto de TSM que utiliza a banda de $11 \mu$ que considera apenas o período diurno. Os processamentos dos algoritmos de TSM e CSM foram os descritos por Brown e Minnett et al. (1999) e Hu et al. (2012), respectivamente. 


\section{Tratamento dos dados}

\section{Parametrização dos processos}

\section{Campo de Ventos}

A extensão e a posição da grade de ventos que melhor se correlaciona com a temperatura de fundo foi determinada utilizando-se mapas de correlação entre as séries temporais da temperatura a $38 \mathrm{~m}$ (fundo) e de cada ponto da grade inicial de ventos. Foi utilizado o vento integrado dos 8 dias anteriores a data de cada coleta in situ para elaborar os mapas de correlação do vento zonal e do vento meridional, a fim de identificar uma área de máxima correlação que tenha significado físico direto.

Com o intuito de compreender melhor o papel do vento em relação ao transporte de Ekman perpendicular à costa e possíveis correntes barotrópicas geradas pelo vento ao longo da costa, a orientação da linha de costa e as isóbatas também foram consideradas, de modo que houvesse maior cobertura da área ao longo da linha de costa. O campo de vento foi rotacionado em componentes paralelas e perpendiculares à costa, utilizando o ângulo de $23^{\circ}$ para determinar a rotação do eixo.

Após definida a escala espacial do campo de vento, a escala temporal foi determinada realizando a convolução dos ventos com a temperatura de fundo. Os ventos foram suavizados com um filtro Gaussiano passa-baixa, com janela de 2, 20 e 50 dias, uma vez que o sinal de alta frequência dos ventos tende a mascarar as correlações. Identificado o período e o filtro ideal com as máximas correlações com a temperatura de fundo, foram testadas as correlações simples entre o vento e os dados coletados in situ em cada uma das profundidades. As correlações foram realizadas considerando a série completa e separadas por estação do ano. Correlações entre o vento e os dados bioquímicos integrados na coluna de água, também foram feitas.

\section{Imagens de satélite MODIS/AQUA}

As imagens de satélites foram tratadas no software SEADAS 7.1 desenvolvido pelo grupo Ocean Biology Processing Group (OBPG/NASA). Para poder eliminar a cobertura de nuvens foi elaborado um mosaico de imagens para cada dia de coleta da série temporal, 
não excedendo 8 dias anteriores ou posteriores à data da coleta. As diferenças entre as datas das imagens de satélite e dos dados coletados in situ são mostrados na Tabela (1). A diferença média e seu desvio padrão foi $-0,5 \pm 1,6$ dias. Destas imagens foram extraídos transectos de TSM e CSM nas direções T1, T2 e T3 (Figura 2). Esses três transectos foram interpolados linearmente no caso de ausência de dados decorrente da presença de nuvens.

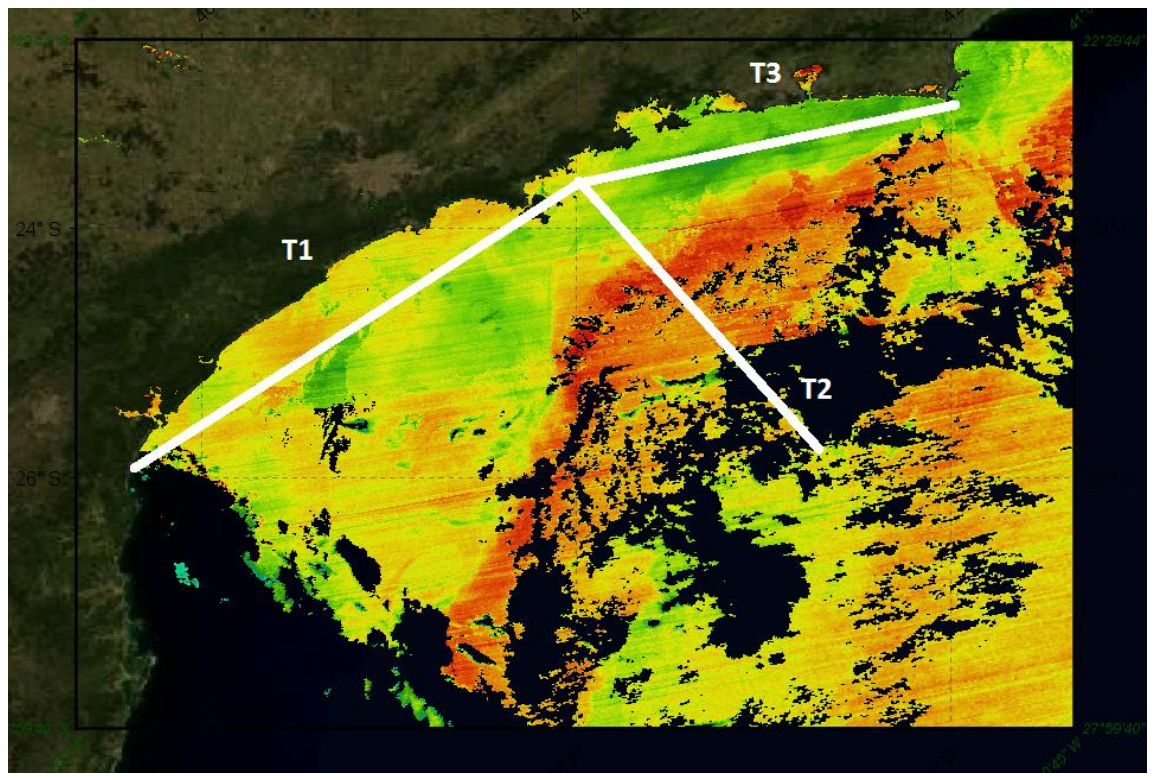

Figura 2: Transectos extraídos das imagens de satélite de temperatura da superfície do mar e clorofila. T1 liga o ponto de coleta ao Estado de Santa Catarina, T2 é aproximadamente ortogonal às isóbatas em direção ao largo (offshore) $e$ o T3 liga o ponto de coleta ao Estado do Rio de Janeiro.

A parametrização para identificar a influência da CB na série temporal de dados in situ foi a distância linear entre a frente interna da $\mathrm{CB}$, identificada através do transecto T2 de TSM e CSM, e o ponto de coleta. Os transectos foram suavizados, a segunda derivada calculada e identificado o máximo local da extremidade ao largo. A escolha da distância final passou pela aprovação visual, feita comparando simultaneamente as imagens de TSM e CSM. O novo máximo local, que apresenta coerência espacial com a imagem bidimensional, foi escolhido caso houvesse discrepância com a imagem original.

Em geral, no inverno há um forte gradiente de TSM e CSM em direção ao oceano, sendo possível identificar a frente interna da CB e sua distância sem ambiguidades entre as imagens. Em contraposição, no verão esse gradiente não é acentuado no campo de TSM. Com a finalidade de verificar se as variações de superfície estão relacionadas à frente da $\mathrm{CB}$, foi analisado um transecto de verão coletado in situ que evidencia presença da Água Costeira (AC), Água Tropical (AT) e ACAS, as quais são comparadas com as 
imagens de TSM e CSM dos respectivos dias. No cruzeiro oceanográfico CARBOM III realizado no período de 25 a 30 de janeiro de 2013, no âmbito do Projeto CARBOM/MCT, foram obtidos dados de temperatura e salinidade da coluna de água ao longo de um transecto ao largo de Santos, SP, para a validação prévia do método de identificação da frente da CB com base nas imagens de satélite.

Foram testadas as correlações simples entre a distância da CB e os dados coletados in situ em cada profundidade da coluna de água. As correlações foram realizadas considerando-se a série completa e separadas por estação do ano. Além disso, foram testadas as correlações simples com os dados bioquímicos integrados na coluna de água.

\section{Análise de séries temporais}

O objetivo das análises de séries temporais é separar as oscilações periódicas das randômicas e aperiódicas associadas ao ruído de fundo (Chatfield, 1989). A transformação do domínio do tempo para o domínio das frequências foi feita ajustandose uma função conhecida ao conjunto de dados. Funções trigonométricas simples são de grande utilidade, por que têm comportamento previsível ao longo do tempo e podem evidenciar a influência ou amplitude de determinado ciclo nas observações. Como na análise de Fourier, a série temporal é decomposta em uma somatória de funções trigonométricas e a premissa inicial assume que os coeficientes e as fases das funções seno e cosseno mudam lentamente na escala temporal estuda. Isso permite estudar diferentes componentes das frequências e calcular a potência de cada ciclo na variância total dos dados.

Uma das premissas da análise de Fourier implica na amostragem regular no tempo. O primeiro problema que surge com a interpolação é a perda de informação em altas frequências, pois suaviza a variância em intervalos menores que o interpolado. Outro problema decorrente da interpolação é a criação do chamado "red-noise" ou ruído de baixa frequência. Neste caso, é criado um sinal sintético que distorce o dado original no espectro de variância, transferindo a energia das altas frequências para as baixas (Schulz e Stattegger, 1997).

Uma alternativa à interpolação em uma série temporal irregular é o método desenvolvido por Lomb (1976), no qual o espectro de frequência é estimado com base no ajuste de mínimos quadrados às funções senoidais de frequências pré-determinadas. Uma consequência natural da regressão de mínimos quadrados, em oposição à transformada 
de Fourier, é que o ajuste do peso de cada componente espectral ocorre à posição temporal real dos dados, o que confere em maior veracidade ao periodograma em baixas frequências. Outra consequência direta deste método é que, caso haja intervalos de tempo menor que o intervalo médio amostrado, o espectro de frequências ainda contém as informações referentes aos ciclos mais curtos. Contudo, o método de Lomb também pode introduzir vieses no periodograma, já que apresenta componentes não necessariamente independentes (ortogonais), superestimentando especialmente as componentes de alta frequência.

Um aprimoramento do método de Lomb é o procedimento REDFIT desenvolvido por Schulz e Mudelsee (2002), onde a serie temporal é dividida em segmentos, calculando-se a média do espectro de frequência (média do segmento sobreposto de Welch) sobrepondo-os em 50\%. Com isso, o ruído é significativamente reduzido a custo da diminuição da resolução espectral. Além disso, a série temporal é ajustada à um modelo $\mathrm{AR}(1)$ de ruído vermelho que diminui o viés em baixas frequências, sendo mais apropriado para testar a hipótese nula que o modelo de ruído branco (média igual a zero e desvio igual a um) utilizado no método de Lomb (1976). O valor crítico para cada frequência é calculado com a aproximação paramétrica $\left(\mathrm{chi}^{2}\right)$ e realizações randômicas de Monte Carlo para o processo AR(1) (Past manual). No entanto, assim como na análise de Fourier, assumiu-se que a série é estacionária, ou que suas frequências de oscilação sofreram poucas alteração ao longo do tempo.

A análise de Fourier ou REDFIT é apropriada para estudar fenômenos marinhos costeiros, como os ciclos em escala maregráfica ou sazonal, uma vez que estas escalas têm periodicidades definidas. As variáveis ecológicas, apesar de não serem determinísticas, também podem ser estudadas utilizando-se a análise de Fourier (Cardon e Iberall, 1970; Steven e Glombitz, 1972; Zoblin, 1973). Nos últimos anos, esta análise foi aplicada em estudos que visam a identificar os padrões cíclicos em comunidades planctônicas, como mostram os trabalhos feitos por Vasseur e Fox (2007) e Beninca et al. (2008).

Porém, conjuntos de dados oceanográficos e meteorológicos podem alterar suas frequências de forma rápida e abrupta em um curto intervalo de tempo. Alguns exemplos de eventos não periódicos que podem introduzir grande variância nas séries temporais oceanográficas são: a intensificação da ocorrência de ciclones extratropicais, florações de fitoplâncton em águas oligotróficas e ressurgências atípicas. 
A análise Wavelet ou ondaleta foi desenvolvida para estudar as frequências mais significativas dos dados e situá-las no tempo, permitindo observar as mudanças das principais frequências ao longo da série temporal. Esta análise tem sido amplamente utilizada em diversas áreas de conhecimento a partir da década de 80 e, recentemente, em estudos ecológicos (Jenouvrier et al., 2005; Keitt e Fisher, 2006; Wittemyer et al., 2008). Em geral, a análise de Wavelet consiste em deslizar um pacote de onda com determinada frequência sobre uma série temporal, aplicando a correlação a cada passo, também chamada de convolução por Bracewell (1986). O resultado é um diagrama de correlação no espaço tempo-frequência, onde a ordenada representa a frequência e a abcissa a localização no tempo (Glover et al., 2011).

O primeiro passo para fazer essa análise é escolher o formato de "onda mãe", definida por uma função com média zero localizada no tempo e no espaço, dada pela seguinte equação:

$$
\psi_{0}(\eta)=\pi^{-1 / 4} e^{i \omega_{0} \eta} e^{-1 / 2 \eta^{2}}
$$

onde: $\omega_{0}$ é a frequência adimensional e $\eta$ é o tempo adimensional.

O valor de $\omega_{0}=6$, que define o pacote de onda Morlet (Figura 3), oferece um bom balanço entre o tempo e a frequência (Grinsted et al., 2004), por isso é utilizado frequentemente em estudos oceanográficos e atmosféricos.

No segundo passo é feita a convolução da onda com a série temporal, sendo os valores de correlação armazenados em cada posição no tempo. A frequência da onda é aumentada e o processo repetido até que a frequência limite seja atingida. Este limite é definido como duas vezes o intervalo de tempo médio amostral ou frequência de Nyquist, o que permite identificar os padrões cíclicos com maior variância ao longo da série, determinar a posição temporal e as frequências/períodos típicos, bem como analisar suas mudanças. 


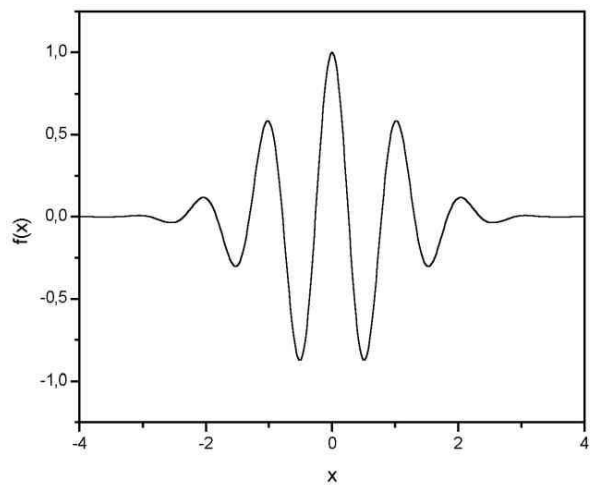

Figura 3: Imagem ilustrativa do pacote de onda Morlet.

Os produtos da análise de Wavelet são: a Transformada Wavelet Contínua (TWC) e sua contrapartida discreta (TWD), a qual é a forma compacta de representação da série temporal e pode ser usada para reduzir o ruído dos dados. A TWC, que permite obter com maior precisão feições no espaço tempo-frequência dos dados, foi utilizada no presente trabalho. O argumento complexo da convolução da série temporal com "onda mãe", normalizada e em determinada frequência, pode ser interpretado como a fase da onda e usado para comparar duas séries temporais que possam estar relacionadas. Por exemplo, adotando-se o sistema de coordenadas polares, se as duas séries estiverem em fase em determinada frequência, a diferença destas fases ou diferença dos ângulos será próximo de $0^{\circ}$ e a correlação positiva. Em contraposição, se estiverem em anti-fase, será $180^{\circ}$ e a correlação negativa. Assim, a partir de duas TWC é possível elaborar a Transformada Wavelet Cruzada (TWX), que revelará regiões com elevada potência em comum.

Semelhante à TWX, a Coerência Wavelet $(\mathrm{CW})$ calcula o coeficiente de correlação localizado no espaço tempo-frequência entre duas TWC, sendo o nível de significância dado pelo método Monte Carlo com 1000 permutações. A TWX detecta as potências comuns das TWC e pode fornecer informações sobre suas fases, enquanto a $\mathrm{CW}$ identifica os comportamentos coerentes das fases por meio da correlação, portanto, normalizada pelos respectivos espectros. Grinsted et al. (2004) descreveram as análises TWC e WC detalhadamente e disponibilizam o código fonte para Matlab ${ }^{\circledR}$ no site <http://noc.ac.uk/using-science/crossWavelet-Wavelet-coherence>, o qual foi utilizado neste estudo.

No presente trabalho foram utilizadas as análises TWC, WTX e CW para identificar a periodicidade do conjunto de dados obtidos in situ (temperatura, nutrientes e clorofila- 
a) e remotos (campo de ventos, TSM e CSM), para poder identificar ao longo da série as mudanças de frequências, frequências cruzadas e coerência de fase. Os dados da distância da $\mathrm{CB}$ e os obtidos in situ foram interpolados para uma média de 30 dias, enquanto os dados de vento subamostrados para 30 dias. Concomitante, foi usada a análise REDFIT para verificar distorções dos resultados da TWC, WTX e CW provocadas pela interpolação regular no tempo, que pode introduzir ruídos de baixa frequência, além de identificar as frequências significativas menores que duas vezes o intervalo médio amostrado. Na análise REDFIT, foi analisado o vento diária com filtro de 2 e 50 dias.

\section{Resultados}

\section{Campo de ventos}

Determinação da grade de ventos

O mapa de correlação do campo inicial de vento com a temperatura de fundo mostra que as correlações têm o padrão típico da circulação de larga escala atmosférica (Figura 4). As maiores correlações positivas ocorreram na componente zonal do vento, cujo coeficiente de correlação atinge valores da ordem de 0,6 na região sudeste-sul da plataforma continental brasileira. No vento meridional, os coeficientes de correlação são menores, principalmente próximo da costa na região sudeste brasileira, mas também atingem valores de 6,0. A integral dos ventos 8 dias antes da data da coleta suavizou os mapas de correlação, porém, com correlações mais fortes com os ventos presentes apenas no dia de coleta.

Núcleos de correlação negativa com valores que chegam a -0,6 na correlação com o vento zonal ocorreram em regiões distantes da área de estudo, próximos da costa da África, tanto no vento zonal como meridional. Valores negativos de correção dos ventos zonais na região polar, coincidente com a região dos jatos polares atmosféricos, também foram registrados. 

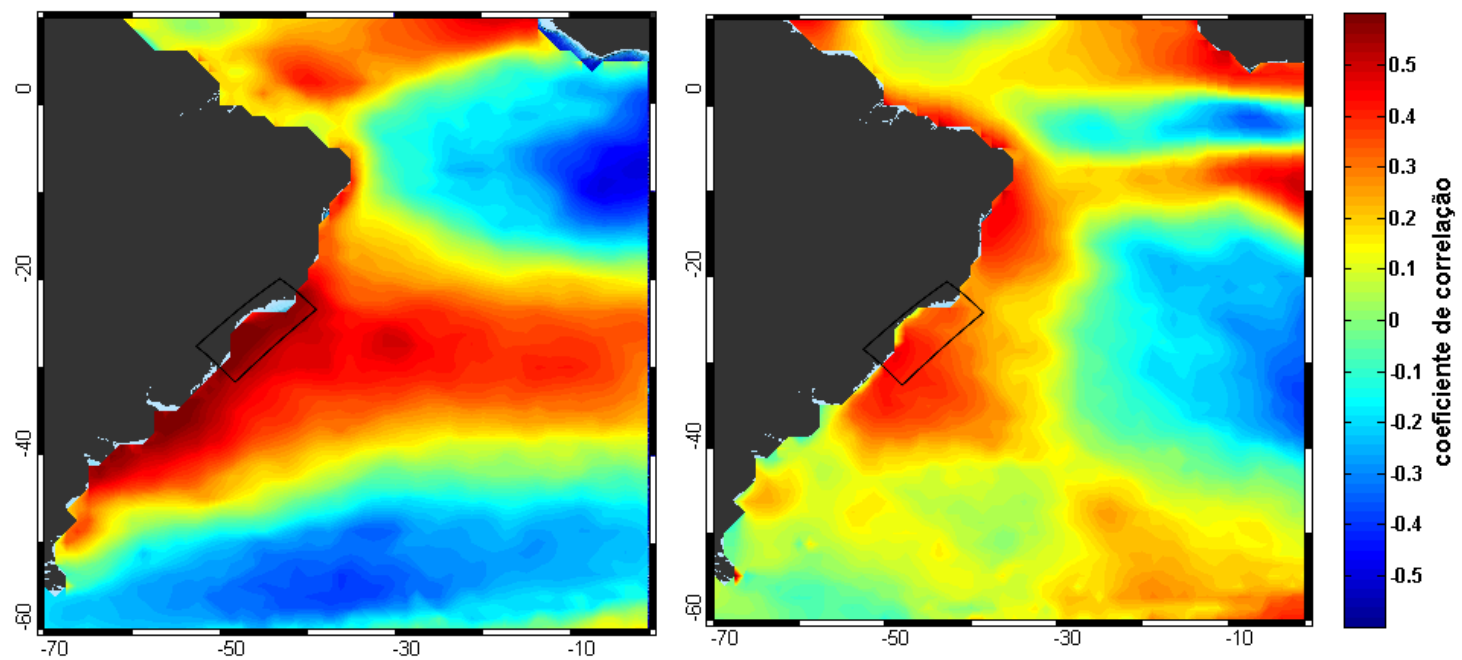

Figura 4: Mapa de correlação dos ventos zonal (esquerda) e meridional (direita) com a temperatura de fundo. $O$ retângulo indica a área da grade de ventos selecionada para realização das análises.

A partir destes resultados, a nova grade de ventos obtida manteve a mesma orientação da linha de costa e a batimetria local (Figura 5).

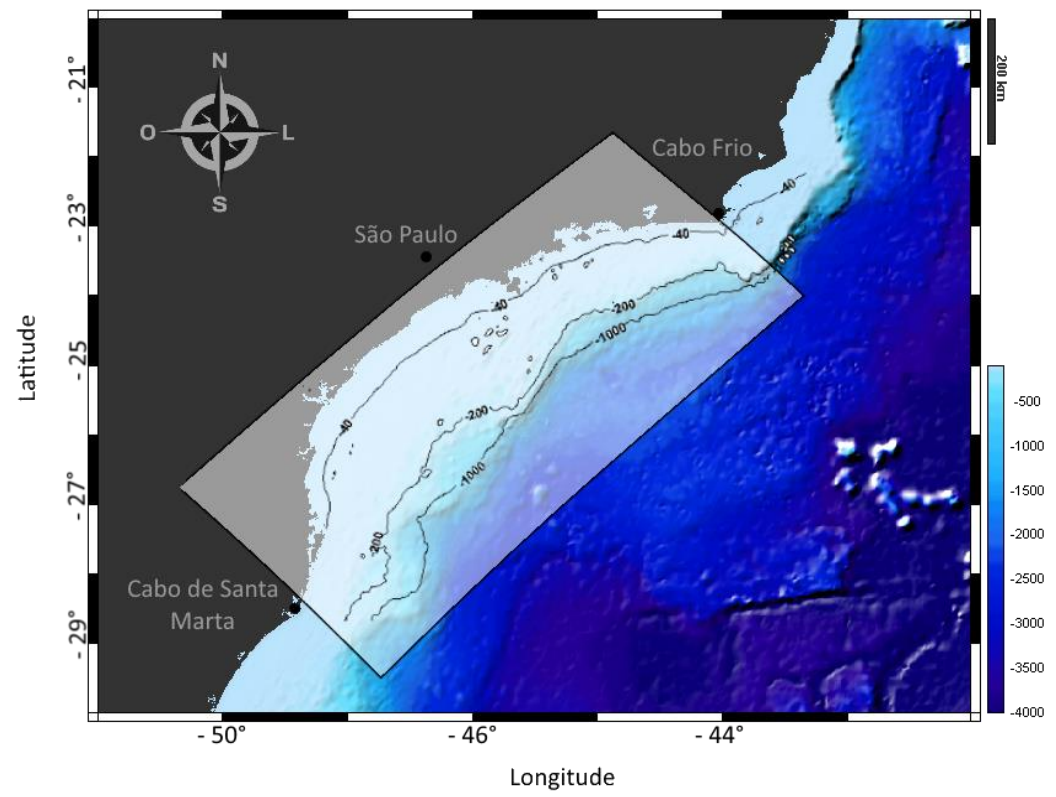

Figura 5: Grade selecionada para elaboração da série temporal dos ventos entre as regiões de Cabo Frio (RJ) e Cabo de Santa Marta (SC), no período de dezembro de 2004 a abril de 2014.

Os dados mostraram que na área selecionada predominaram os ventos de nordeste (Figura 6). No verão houve forte ocorrência de ventos de leste, enquanto no outono foram menos intensos e apresentaram várias direções, com ventos mais intensos de sul-sudoeste. 
No inverno, o vento ficou mais restrito à direção nordeste, apesar da ocorrência de ventos de sudoeste. Na primavera observou-se a dominância ventos de leste-nordeste, porém com ocorrência mais frequente de ventos de sudeste quando comparado com o verão.

\section{Verão}

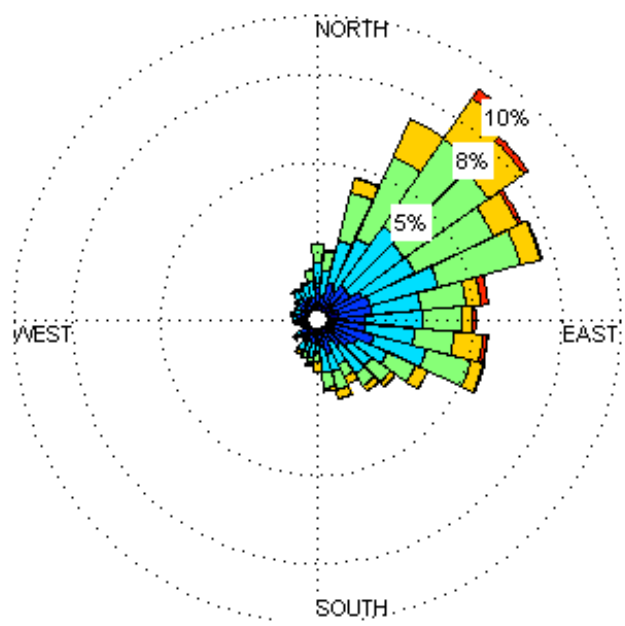

Inverno

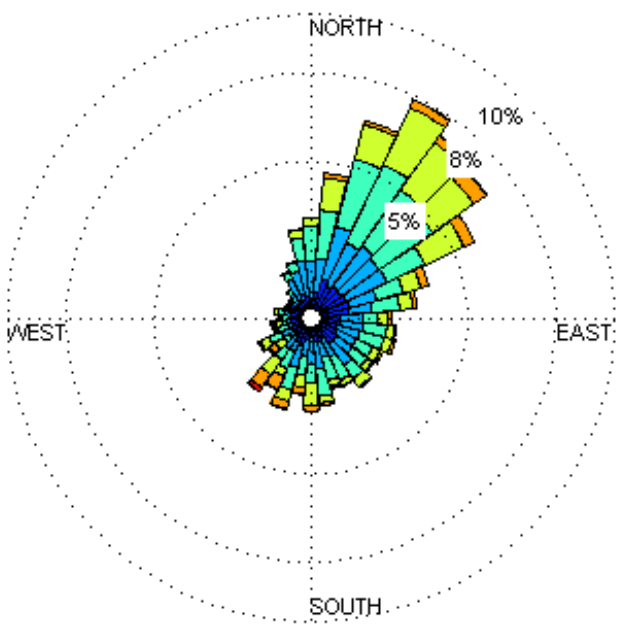

Outono

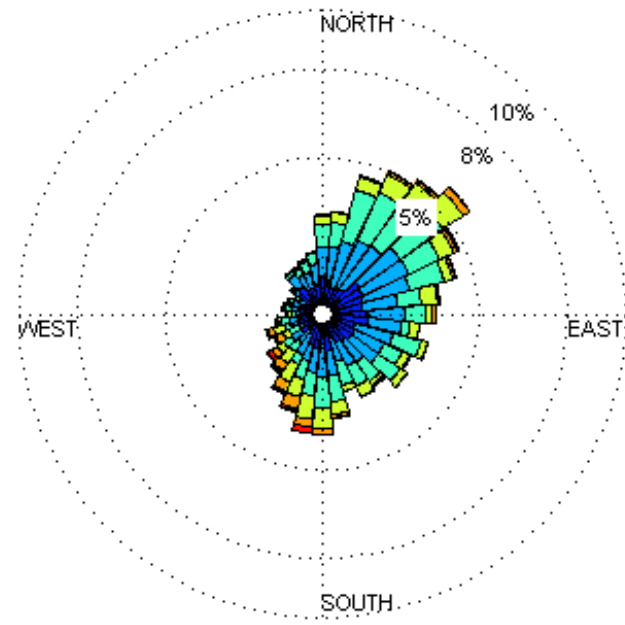

Primavera

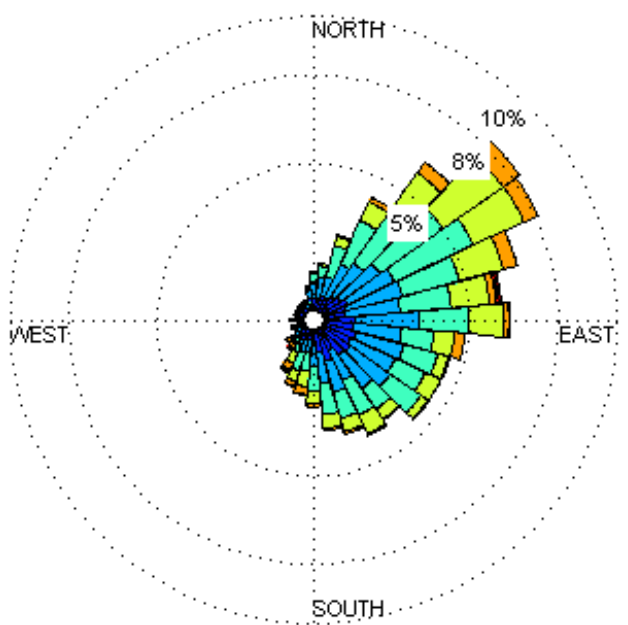

Figura 6: Direção, intensidade e frequência dos ventos, da área selecionada na figura 5, correspondentes ao período de dezembro de 2004 a abril de 2014. A intensidade é dada pela escala de cores.

Ventos paralelos e perpendiculares à costa

Os resultados obtidos no presente trabalho evidenciaram que os ventos da componente paralela à costa foram predominantemente negativos, indicando a dominância do vento de nordeste em toda a série temporal (Figura 7). No período compreendido entre 2010 e 2012, os ventos de sudoeste foram menos frequentes e os 
ventos de nordeste mais constantes. Verificou-se, também, que o vento perpendicular oscilou entre valores positivos e negativos em toda a série.

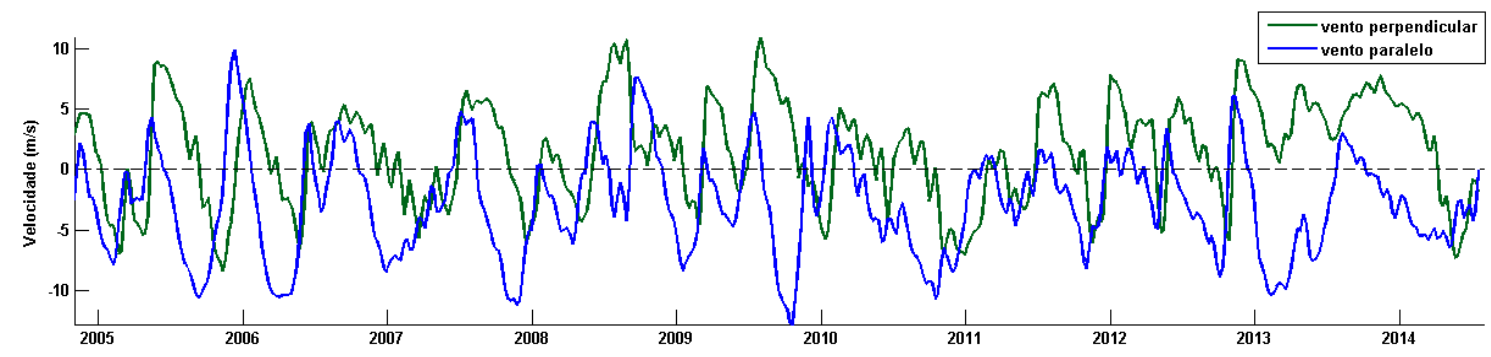

Figura 7: Série temporal da grade de ventos selecionada na figura 5, correspondente ao período de dezembro de 2004 a abril de 2014, aplicando-se um filtro de 30 dias.

\section{Imagens de TSM e CSM}

\section{Determinação da frente da $C B$}

A partir de um mosaico de imagens de CSM, a frente da CB foi identificada no verão. Sobre o transecto, a frente externa oceânica delimitada pela mudança do azul-claro para o azul da imagem de CSM (Figura 8), esteve associada provavelmente à frente da CB, enquanto na imagem de TSM a presença desta frente não foi evidente.

Analisando o transecto de salinidade, obtido a partir de dados coletados na campanha CARBOM III (Figura 9), verificou-se que a interceptação da AT na superfície, que corresponde à frente da CB, ocorreu entre 173 e $215 \mathrm{~km}$ da costa. Esta informação é coerente com a obtida ao analisar o transecto CSM, o qual revelou um aumento das concentrações a partir de $204 \mathrm{~km}$ da costa. Este gradiente é mais evidente na segunda derivada CSM (Figura 10). Assim, foi possível calcular as distâncias da frente da CB dos meses de verão baseadas nas imagens de CSM. 

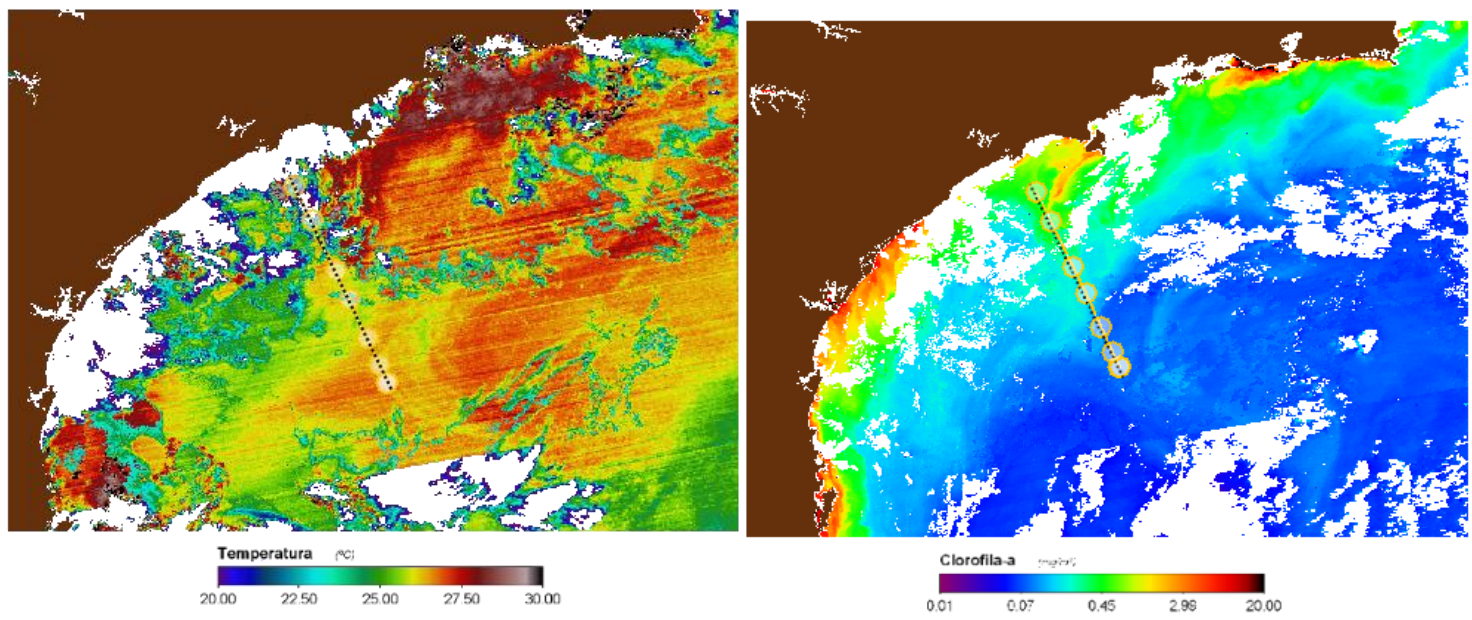

Figura 8: Mosaico de duas imagens de TSM (direita) e clorofila (esquerda) dos dias 25 e 27 de janeiro de 2013. A posição do transecto coletado pelo CARBOM III é dada pela linha tracejada e as estações são dadas pelos círculos amarelos.

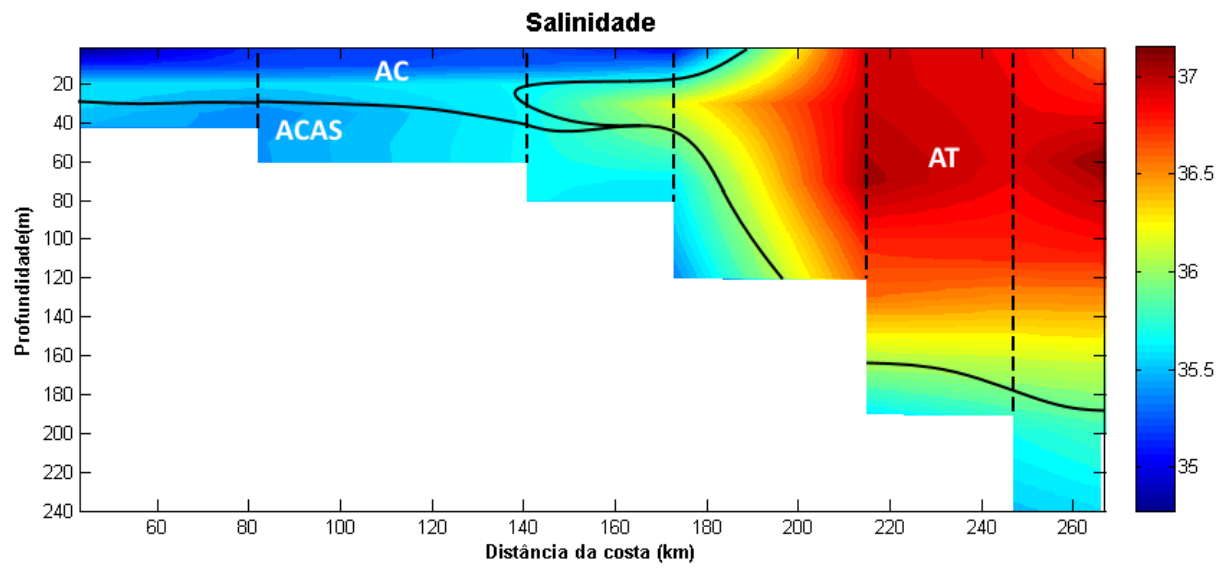

Figura 9: Transecto de salinidade coletado entre os dias 25 e 30 de janeiro de 2013. As linhas tracejadas são as posições das estações de coleta. Os dados foram interpolados lateralmente.
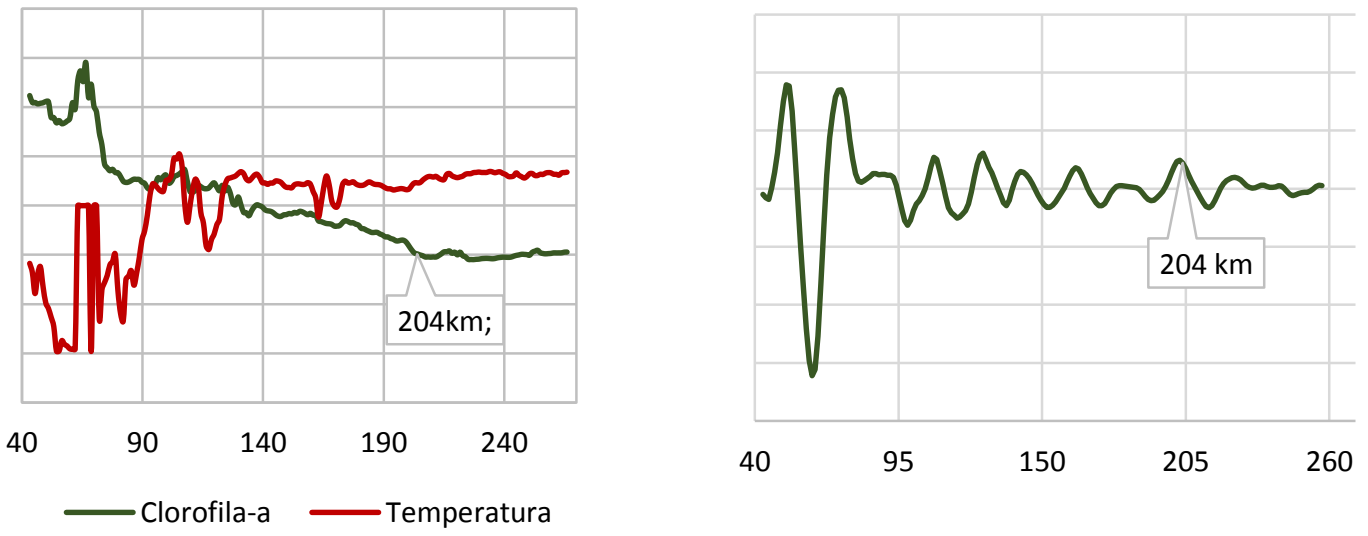

Figura 10: Á esquerda os transectos de TSM (linha vermelha) e CSM (linha verde) normalizados e à direita a segunda derivada do transecto de CSM. Os rótulos indicam a posição da frente da CB e a respectiva distância da costa. 


\section{Distância da $C B$}

A partir das imagens de CSM e da segunda derivada do transecto, foi obtida a série temporal da distância da CB em relação ao ponto de coleta (Figura 11). O sinal sazonal da distância da $\mathrm{CB}$ em relação ao ponto de coleta não é evidente. A alternância de máximos e mínimos entre os menores intervalos amostrados expressa grande variabilidade de alta frequência. No período compreendido entre 2005 e 2008 as distâncias parecem, em média, menores que o restante da série, o que indica a existência de variabilidade interanual.

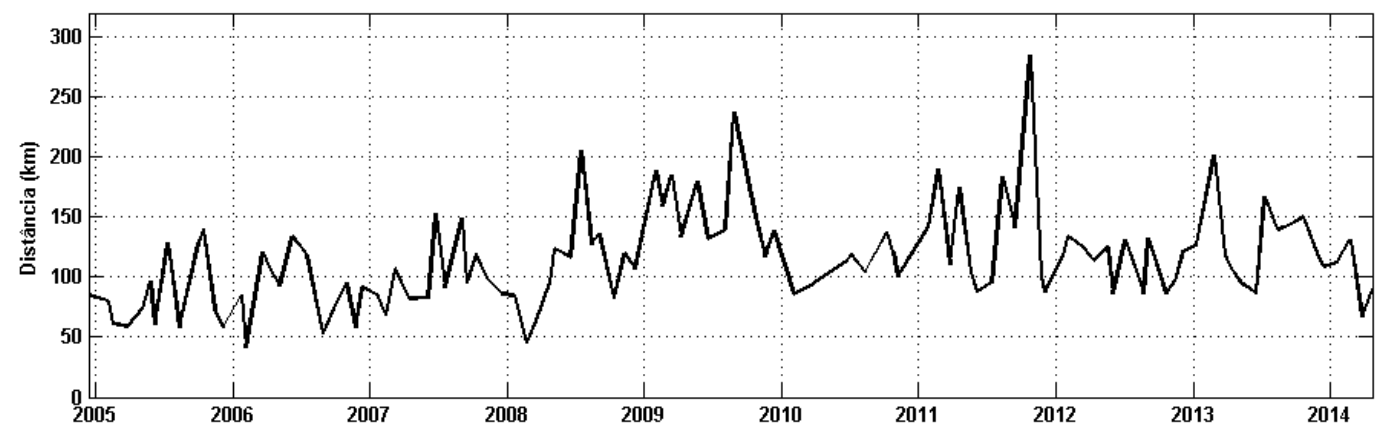

Figura 11: Distância entre a frente da CB e o ponto de coleta ao largo de Ubatuba, Estado de São Paulo no período compreendido entre dezembro de 2004 a abril de 2014.

\section{Transectos de TSM e CSM}

Os resultados obtidos no presente trabalho indicam que os transectos de TSM tiveram ciclo sazonal definido (Figura 12). Considerando a temperatura média ao longo do transecto, o T1 teve as maiores amplitudes em relação às outras regiões, destacandose as baixas temperaturas nas regiões mais distantes do ponto de coleta, especialmente, no inverno de 2007. O transecto T2 apresentou a máxima temperatura média $\left(24,2^{\circ} \mathrm{C}\right)$, enquanto o T3 a máxima amplitude em relação a todos os valores da série, sendo a máxima de $31,1^{\circ} \mathrm{C}$ e a mínima $13,9^{\circ} \mathrm{C}$, além do maior gradiente ao longo do transecto. No T3 também foi possível observar uma mudança no padrão da temperatura entre o final de 2011 e início de 2012, principalmente nas regiões distantes do ponto de coleta. Todos os transectos tiveram as maiores temperaturas no verão de 2010 , ultrapassando os $30^{\circ} \mathrm{C}$, presente também no verão de 2011 no T1. 

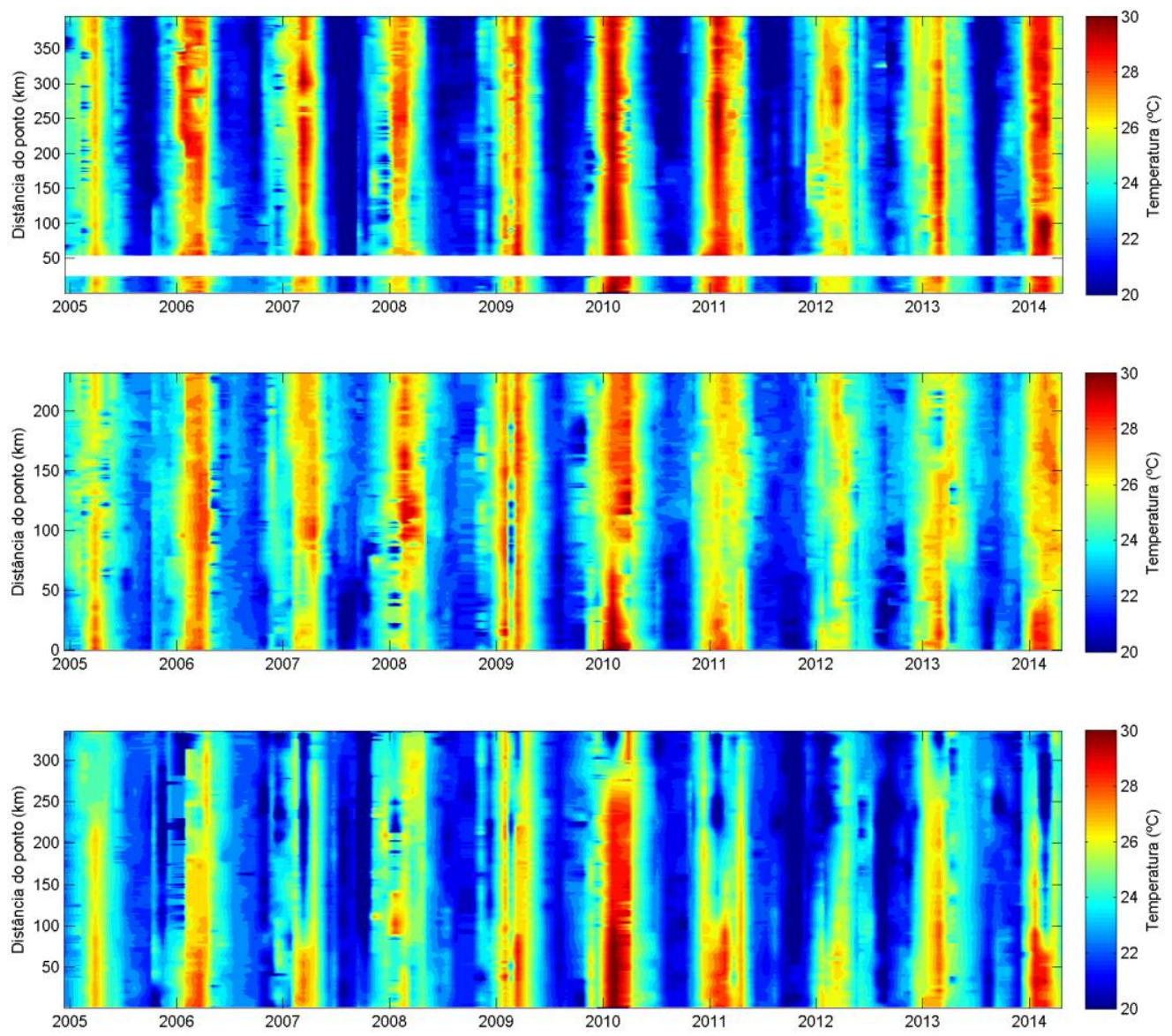

Figura 12: Série temporal dos transectos de TSM obtidos nos dias de coleta realizadas entre dezembro de 2004 a abril de 2014. De cima para baixo: T1, T2 e T3.

Os dados obtidos mostram que na série temporal dos transectos de CSM o ciclo sazonal não foi evidente. Descontinuidades das CSM entre os menores intervalos amostrados foram observadas (Figura 13). O transecto T1 teve as máximas concentrações além dos $350 \mathrm{~km}$ de distância do ponto de coleta e máximos secundários mais próximos. Destaca-se as máximas concentrações ao longo do T1 no inverno de 2007, também observadas na região próxima ao ponto de coleta no T2, coincidente com as mínimas temperaturas observadas no T1 de TSM. Também houve concentrações elevadas de CSM no T1 e T2 próximas ao ponto de coleta em outono de 2010 e primavera de 2011. Foi possível observar no T2 um máximo de concentração entre 120 e 220 km ao largo no inverno de 2010, com duração de 3 meses e outros valores elevados ao longo do transecto no inverno de 2012. O T3 teve as maiores concentrações medias. Na região mediana deste transecto foi observada a ocorrência de eventos de máximos na primavera de 2005, 2007, 2011 e 2012. 

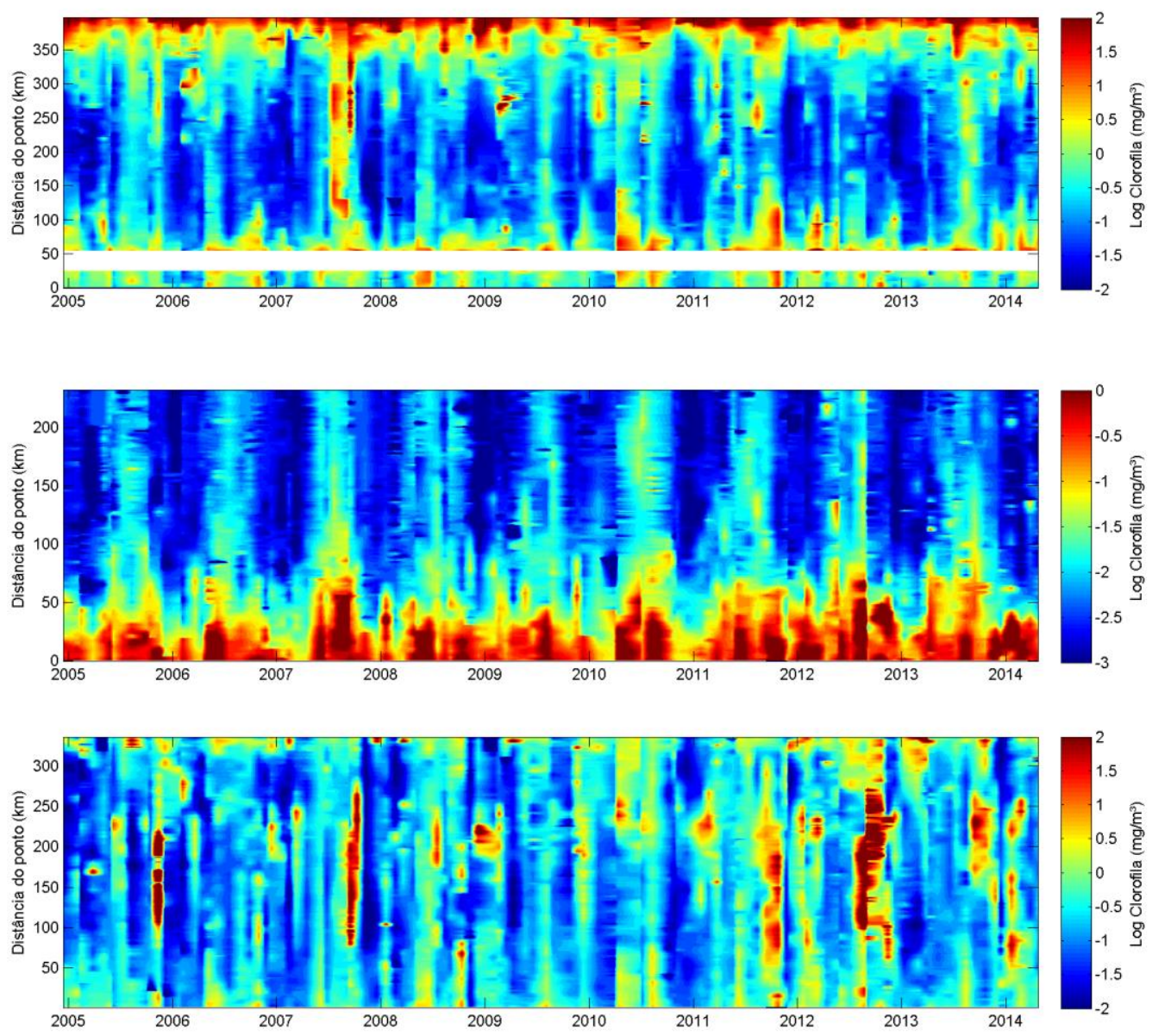

Figura 13: Série temporal dos transectos de CSM obtidos a partir de dados do Satelite MODIS/AQUA. De cima para baixo observa-se o $T 1, T 2$ e $T 3$.

\section{Dados obtidos in situ}

Os dados de temperatura evidenciaram que ciclo anual é bastante pronunciado (Figura 14). A alternância entre períodos de estratificação e homogeneidade é regular, indicando a presença da ACAS em todos os anos de coleta, embora sua intrusão fosse menos pronunciada e restrita à primavera de 2010. No inverno deste ano a temperatura esteve mais elevada em toda a coluna de água quando comparada com a dos outros anos. Nos verões de 2012 e 2013 a ACAS aflorou na superfície, o que caracteriza um evento de ressurgência, sendo a intrusão mais intensa na primavera e verão de 2012. A temperatura de superfície foi mais elevada em fevereiro de 2014 chegando a ultrapassar os $28^{\circ} \mathrm{C}$. 


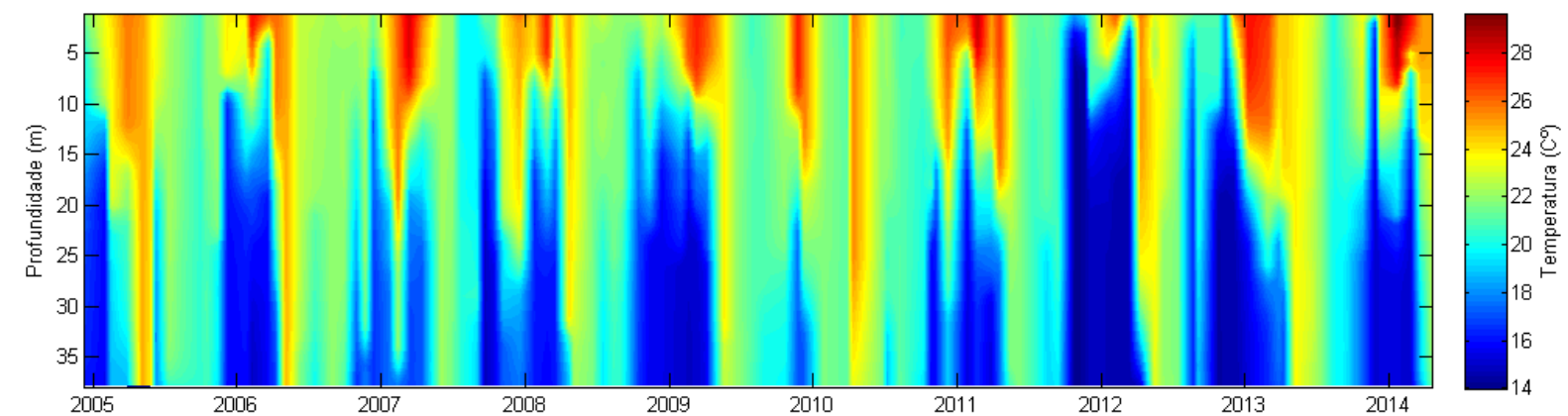

Figura 14: Série temporal de temperatura obtida in situ ao largo de Ubatuba, Estado de São Paulo, no período de dezembro de 2004 a abril de 2014.

Os resultados mostraram que as séries temporais de nitrato e fosfato foram semelhantes às de temperatura, bem como a ocorrência de ciclos sazonais. As maiores concentrações destes nutrientes estiveram associadas à presença da ACAS. Verificou-se que o verão de 2010 apresentou as menores concentrações de nitrato e fosfato, enquanto as de amônia foram elevadas. No verão de 2011 os valores de amônia mantiveram-se elevados em toda a coluna de água. Ao que tudo indica, tanto a amônia como o silicato não tiveram relação direta com a presença da ACAS. 

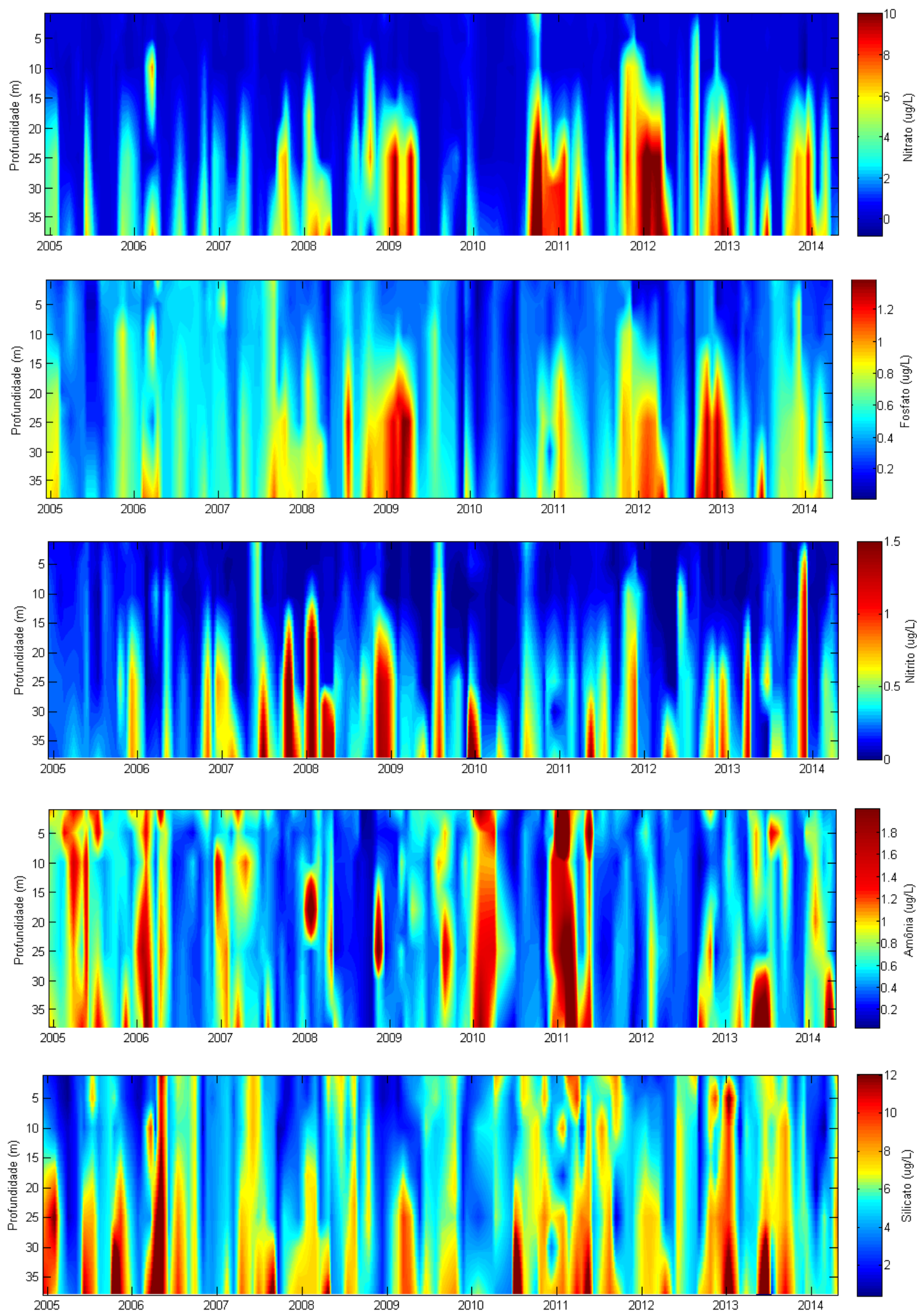

Figura 15: Série temporal dos nutrientes obtidos in situ ao largo de Ubatuba, Estado de São Paulo, no período compreendido entre dezembro de 2004 e abril de 2014. 
Os dados mostram que as concentrações de clorofila- $a$ ultrapassaram 7,0 $\mu \mathrm{g} / \mathrm{L}$ $\left(2^{\log (3)}\right)$, indicando a presença de florações na série (Figura 12). As maiores concentrações de clorofia- $a$ foram registradas em subsuperfície, tanto na primavera como no verão. No ano de 2012 ocorreu uma floração com duração de 3 meses e outra mais intensa em 2013, indicada pelos elevados valores de clorofila- $a$ registrados na área $(18 \mu \mathrm{g} / \mathrm{L})$. Em contraposição, em 2010 as baixas concentrações de clorofila- $a$ coincidiram com as elevadas temperaturas e concentrações de amônia.

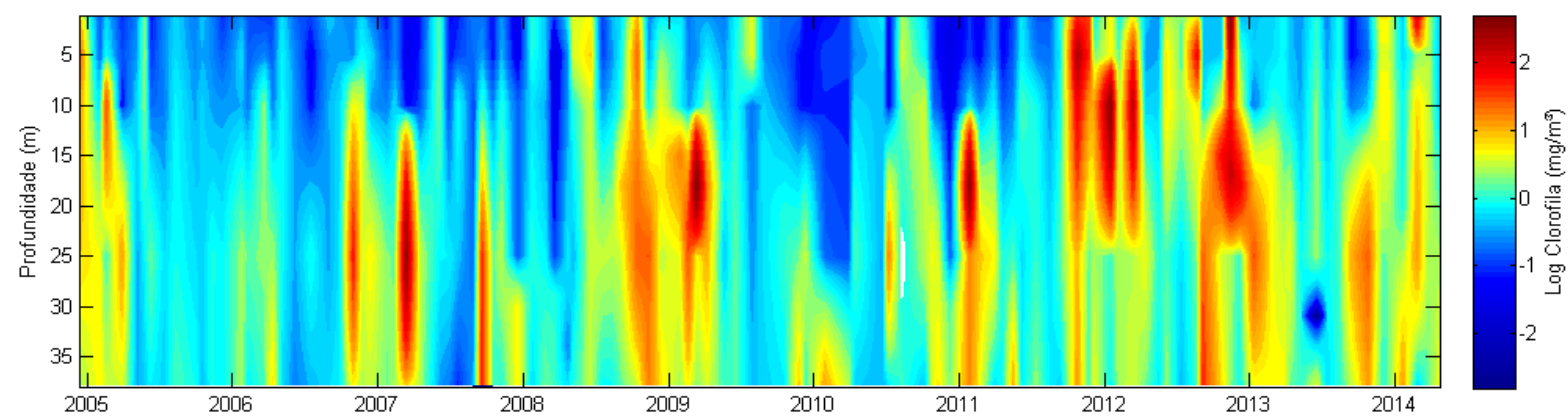

Figura 16: Série temporal de clorofila-a obtida in situ ao largo de Ubatuba, Estado de São Paulo, no período compreendido entre dezembro de 2004 e abril de 2014.

\section{Convolução e correlações simples}

Correlações entre os ventos e as variáveis obtidas in situ

Verificou-se que na componente paralela à costa as correlações foram significativas com até 42 dias de atraso, independente do filtro usado. A máxima correlação registrada foi 0,70 entre o vento paralelo à costa com filtro de 50 dias e atraso de 15 dias. As correlações do vento com filtro de 2 dias tiveram máximos de 0,48 e 0,45 com 10 e 20 dias de atraso, respectivamente. 

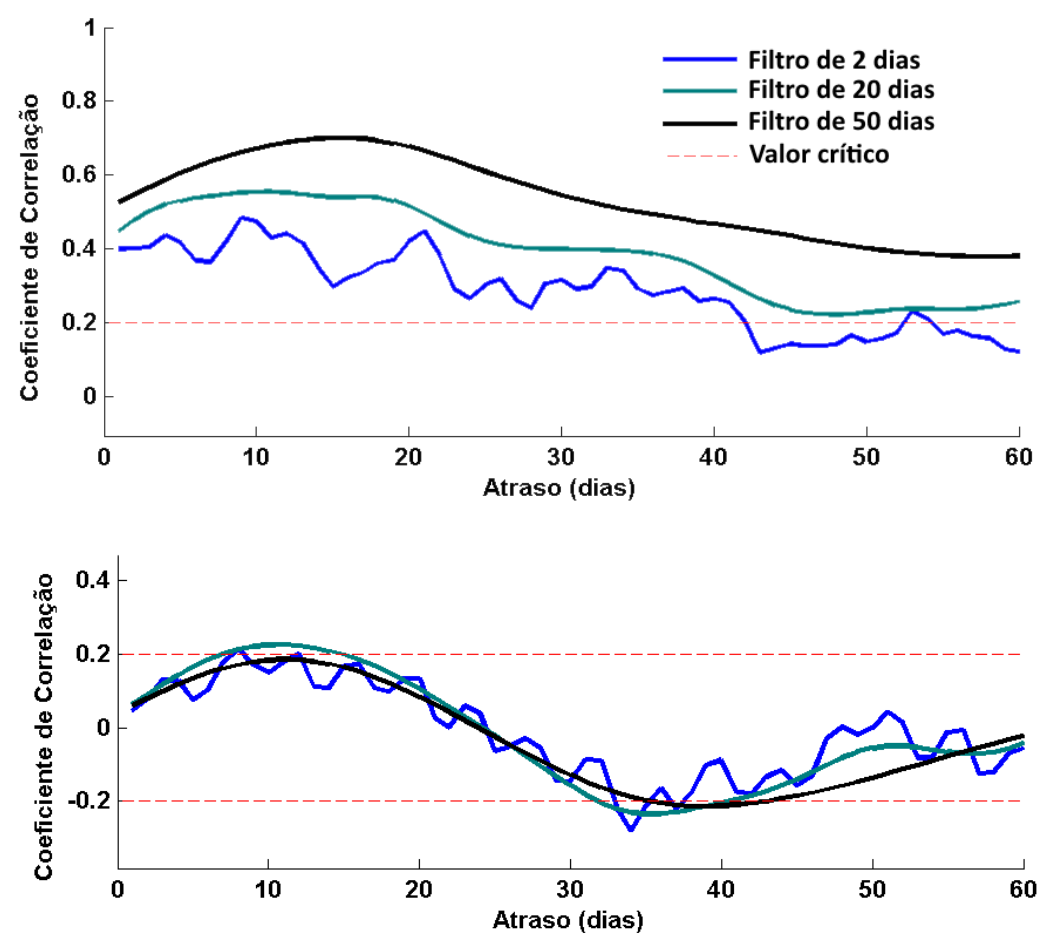

Figura 17: Convolução entre os ventos paralelo (gráfico superior) e perpendicular (gráfico inferior) e a temperatura de fundo. A linha tracejada vermelha indica o valor crítico $(p=0,05 ; N=110)$.

Os dados evidenciaram que a componente do vento perpendicular à costa e a temperatura de fundo não apresentaram correlação, mesmo considerando o atraso entre as séries, bem como a existência de correlações marginalmente significativas entre 10 e 35 dias de atraso. Os dados mostraram, também, que não houve mudança das correlações com relação aos diferentes tratamentos dos ventos. Isto permite inferir que a escala temporal ideal para análise dos ventos foi 15 dias anteriores à data da coleta com filtro de 50 dias.

A dispersão dos valores de temperatura de fundo e o vento paralelo, com filtro de 50 dias e atraso de 15 dias, apresentou coeficiente de determinação 0,49 (Figura 18). No outono foi possível verificar a presença de ventos médios paralelos positivos e as máximas amplitudes de temperaturas de fundo, enquanto na primavera e no verão os valores dos ventos médios foram negativos e intensos, relacionados as temperaturas mínimas. No verão a temperatura apresentou uma distribuição mais homogeneidade que as demais estações. 


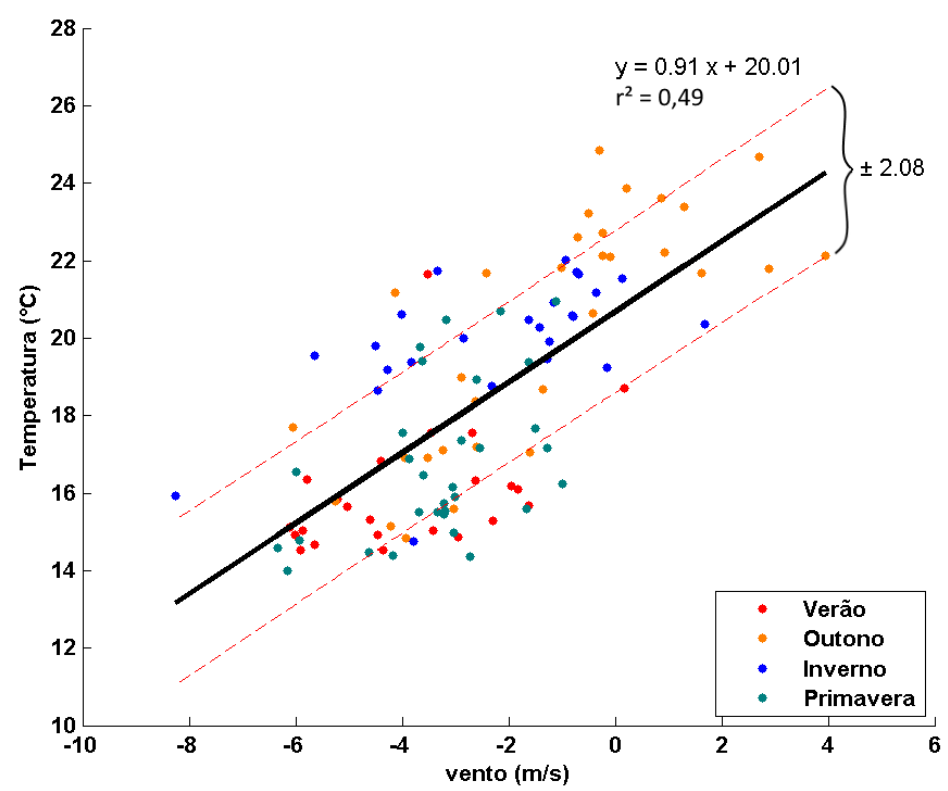

Figura 18: Dispersão dos valores de temperatura de fundo e o vento paralelo, com filtro de 50 dias e atraso de 15 dias. A linha preta representa a reta de regressão linear considerando a série completa e o espaço entre as linhas vermelhas o intervalo que contém $50 \%$ dos pontos.

A correlação da série completa de vento paralelo a de temperatura em cada profundidade da coluna de água aumentaram da superfície em direção ao fundo, o mesmo aconteceu no outono e no inverno (Figura 19). A máxima correlação ocorreu no outono com relação à temperatura de fundo, cujo coeficiente de correlação atingiu 0,77 , enquanto na superfície a correlação foi negativa. Na primavera foram registrados os maiores valores de correlação entre 8 a 20 m, sendo o valor máximo $(0,62)$ obtido a $18 \mathrm{~m}$. O padrão das correlações no verão foi semelhante ao da primavera e o do inverno semelhante ao padrão do outono. 


\section{Temperatura}
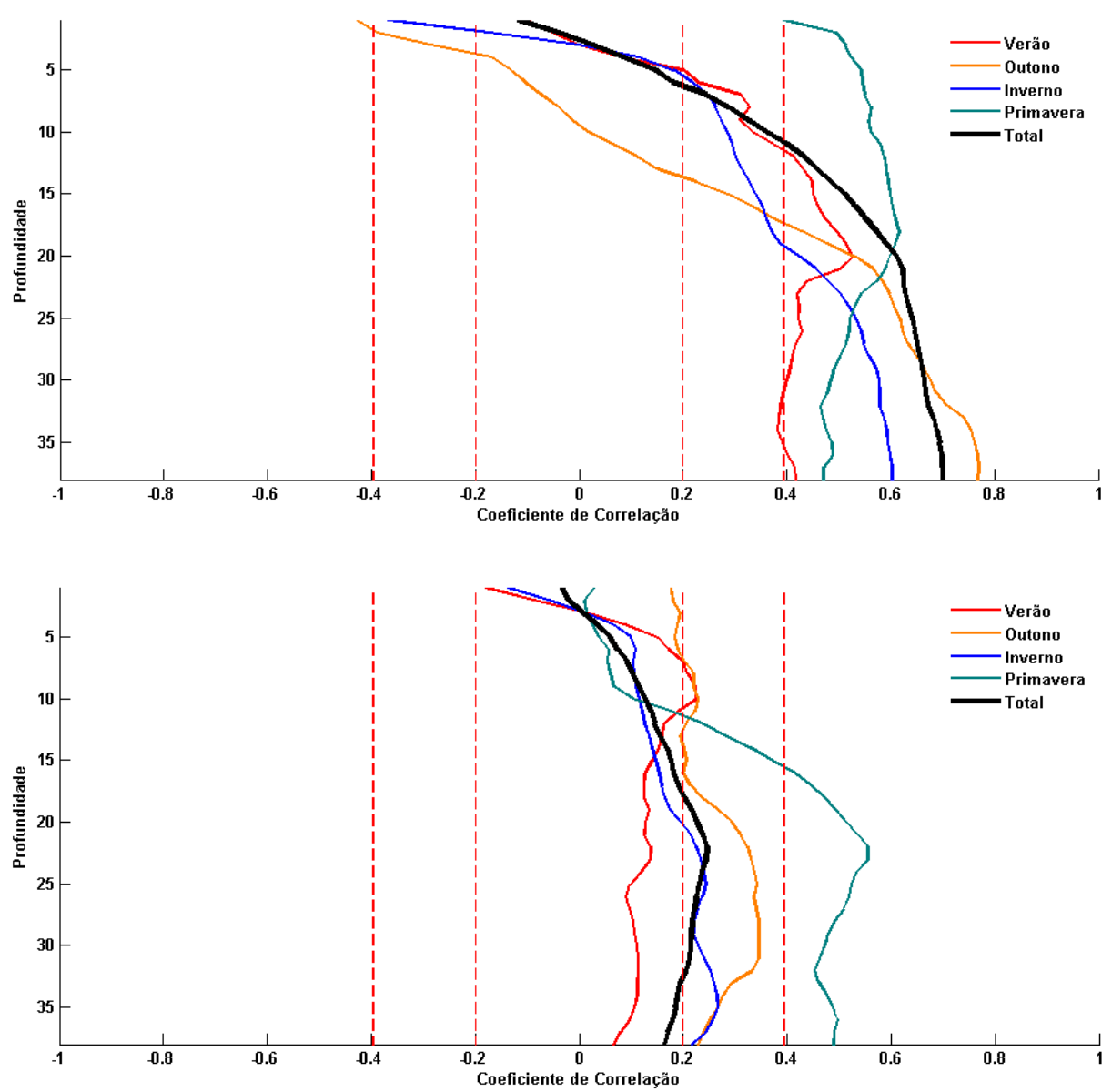

Figura 19: Correlação entre os ventos paralelo (gráfico superior) e perpendicular (gráfico inferior) com a temperatura registrada em diferentes profundidades. As linhas tracejadas vermelhas finas indicam os valores críticos do coeficiente de correlação para $N=110$ (total) e as grossas para $N=23$ (por estação), com $p=0,05$.

Em geral, as correlações do vento perpendicular e a temperatura do ano foram positivas e marginalmente significativas. Na primavera, o valor máximo de correlação foi 0,55 em $22 \mathrm{~m}$, enquanto a série completa apresentou valores significativos positivos entre 19 e $32 \mathrm{~m}$ de profundidade.

Os resultados mostraram que na série total, as correlações do vento paralelo com a clorofila- $a$ foram negativas em toda coluna de água e que na primavera atingiu valores menores que -0,6, especialmente, nos primeiros metros de profundidade (Figura 20). No inverno essas correlações foram marginalmente significativas, sendo os maiores valores registrados em 5 e $25 \mathrm{~m}$. O outono apresentou correlações de superfície opostas em relação às outras estações do ano, com valores acima de 0,4. No caso do vento perpendicular, as correlações foram semelhantes às do vento paralelo na primavera, com 
valores próximos a -0,5. A correlação com os dados de verão também foi significativa entre 5 e $15 \mathrm{~m}$. Considerando-se a série total, os ventos perpendiculares tiveram correlação negativa com a clorofila- $a$ entre 8 e 23 m.

Os dados obtidos evidenciaram, também, que o fosfato apresentou correlações significativas em todas as estações do ano com o vento paralelo à costa, e que o padrão de correlação na primavera e no verão foi semelhante abaixo dos $20 \mathrm{~m}$ de profundidade (Figura 21). A máxima correlação ocorreu no outono, no fundo, sendo os valores menores que -0,5. Em contraposição, na superfície houve inversão do sinal de correlação. A máxima correlação positiva foi registrada no inverno, na superfície, seguida pelo outono a 5 m. Com relação ao vento perpendicular, a correlação significativa $(-0,44)$ ficou restrita aos $25 \mathrm{~m}$.

O nitrato teve máxima correlação com o vento paralelo à costa no inverno, com valores $-0,77$ em $20 \mathrm{~m}$. A série completa seguiu o mesmo padrão do inverno, com valores que não ultrapassaram -0,5 entre 20 e 35 m. No verão, as correlações foram significativas a partir de $16 \mathrm{~m}$, enquanto o outono apresentou a máxima correlação de fundo $(-0,67)$. Com relação ao vento perpendicular, verificou-se que não houve correlações significativas, exceto no verão à profundidade $5 \mathrm{~m}$.
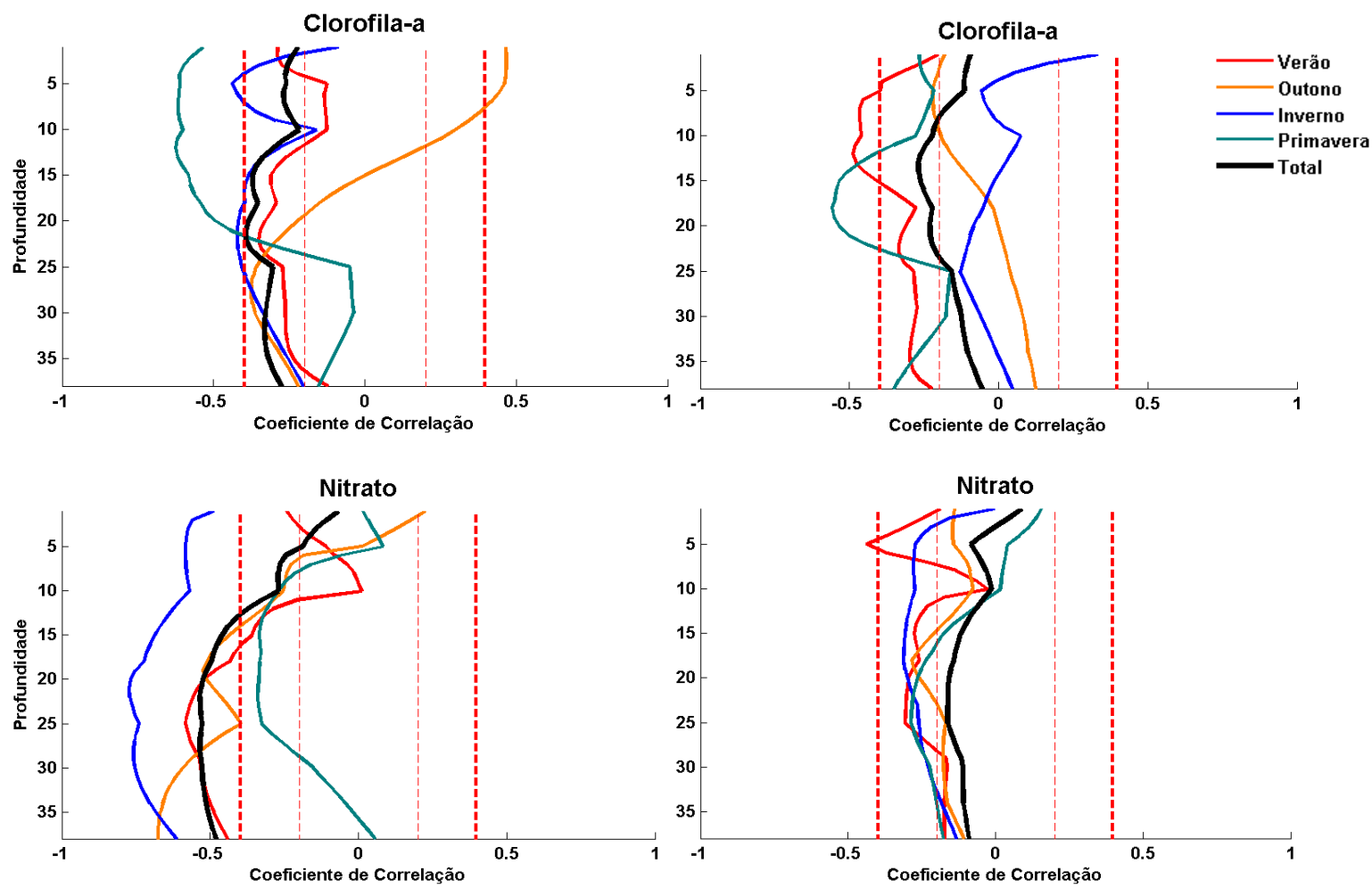

Figura 20: Correlação entre vento paralelo (esquerda) e o perpendicular (direita) com as variáveis obtidas in situ por profundidade. As linhas tracejadas vermelhas finas indicam os valores críticos do coeficiente de correlação para $N=110$ (total) e as grossas para $N=23$ (por estação), com $p=0,05$. 

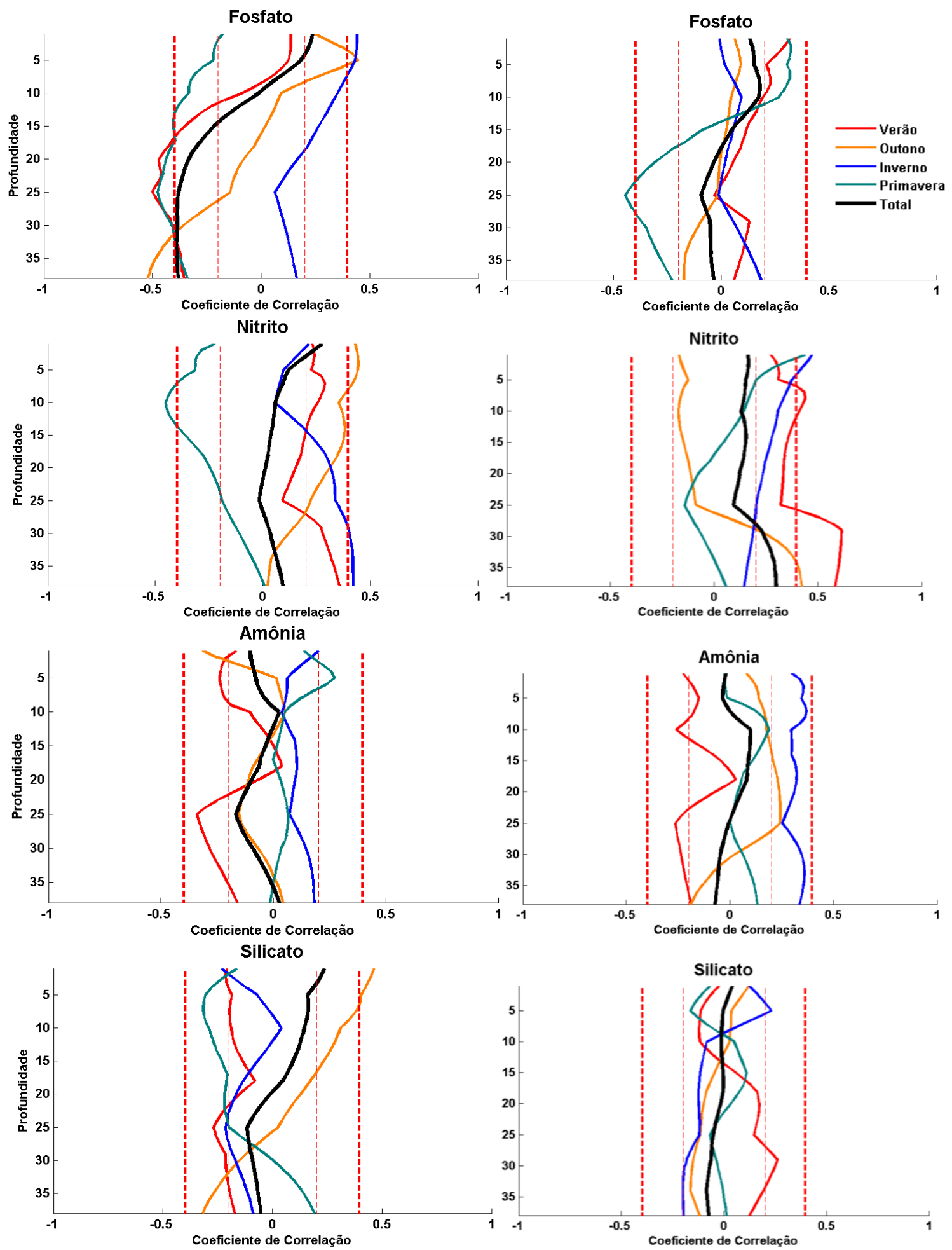

Figura 21: Correlação entre vento paralelo (esquerda) e o perpendicular (direita) com as variáveis obtidas in situ por profundidade. As linhas tracejadas vermelhas finas indicam os valores críticos do coeficiente de correlação para $N=$ 110 (total) e as grossas para $N=23$ (por estação), com $p=0,05$. 
Correlações entre distância da CB e as variáveis obtidas in situ

Em geral, poucas correlações significativas entre a distância da CB e as variáveis obtidas in situ foram registradas no período de estudo, não sendo registradas correlações na série temporal completa (Figura 22 e Figura 23). No entanto, correlações positivas a $25 \mathrm{~m}$ de profundidade foram encontradas nos dados de clorofila- $a$, nitrato e fosfato no verão. Ainda nesta estação do ano, correlações negativas marginalmente significativas com relação à temperatura foram observadas a $30 \mathrm{~m}$ e na primavera a $5 \mathrm{~m}$. Com relação à clorofila- $a$ e o nitrato, também foram obtidas correlações positivas a $5 \mathrm{~m}$ na primavera, sendo marginalmente significativas no caso do nitrato. Foi possível verificar a existência de correlação nos dados de amônia a 25 m no inverno. No caso do nitrito e da amônia, correlações negativas foram registradas entre 5 e $15 \mathrm{~m}$, respectivamente.
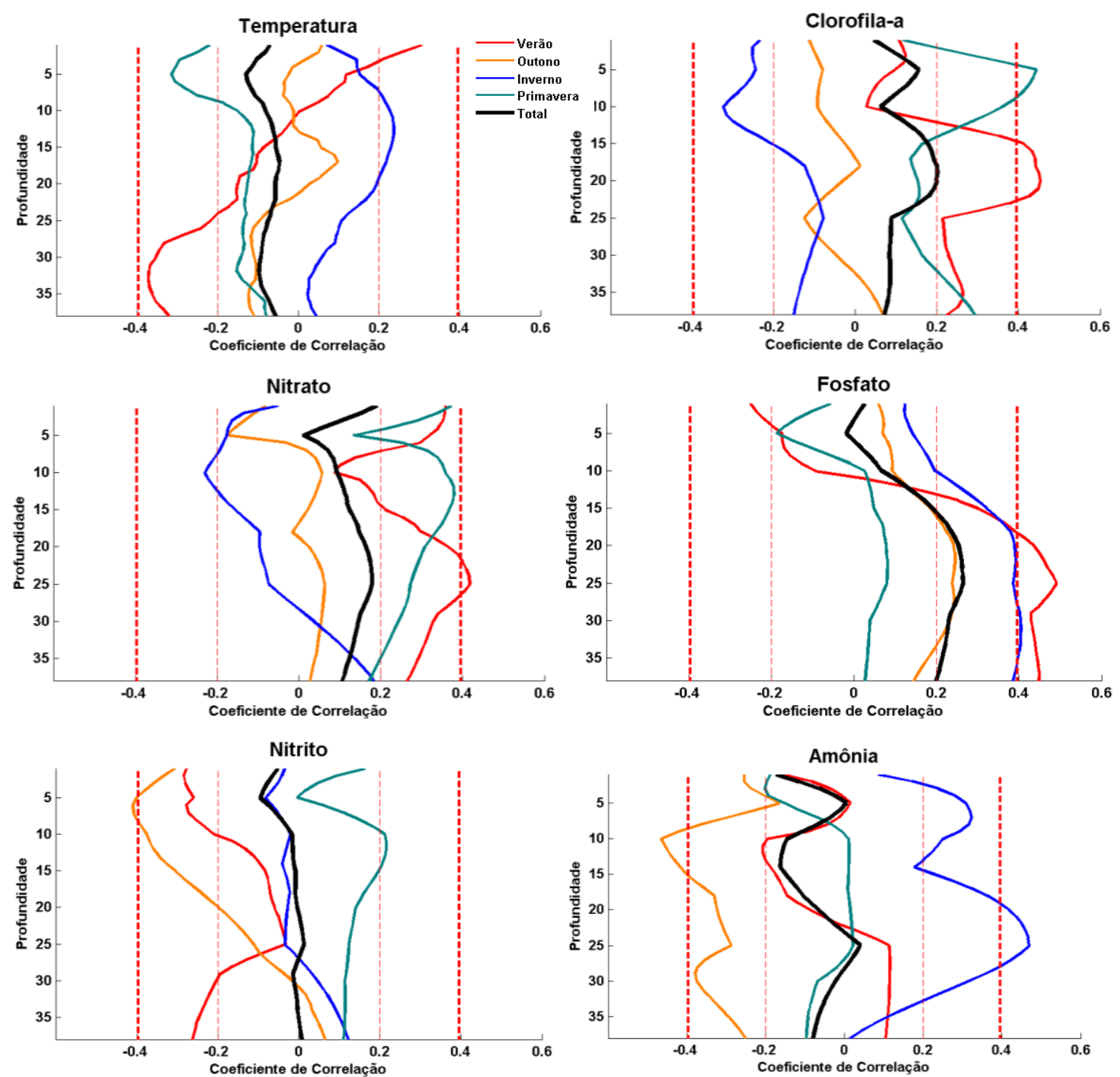

Figura 22: Correlação entre a distância da CB com as variáveis obtidas in situ por profundidade. As linhas tracejadas vermelhas finas indicam os valores críticos do coeficiente de correlação para $N=110$ (total) e as grossas para $N=$ 23 (por estação), $\operatorname{com} p=0,05$. 


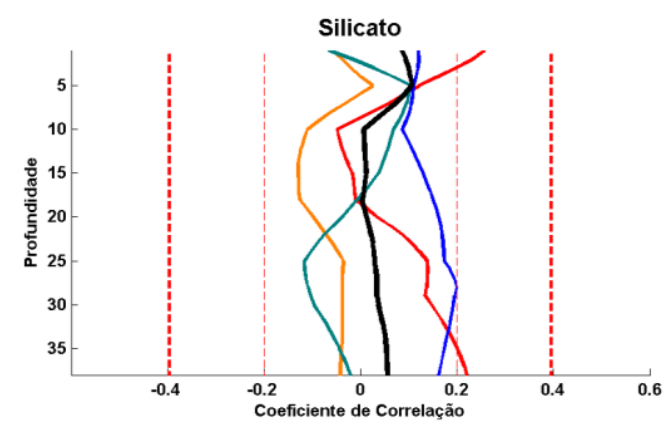

Figura 23: Correlação entre a distância da CB com as variáveis obtidas in situ em diferentes profundidades, ao largo de Ubatuba, Estado de São Paulo. As linhas tracejadas vermelhas finas indicam os valores críticos do coeficiente de correlação para $N=110$ (total) e as grossas para $N=23$ (por estação), com $p=0,05$.

As correlações entre os ventos, a distância da $\mathrm{CB}$, a temperatura de fundo e as variáveis bioquímicas integradas na coluna de água estão sumarizadas na Tabela 1. A distância da CB teve correlação negativa com o vento paralelo, correlação positiva com fosfato e correlação marginalmente significativa com a clorofila- $a$. A maior correlação ocorreu entre o vento paralelo e a temperatura de fundo $(0,70)$. O vento paralelo também teve correlações positivas em relação ao vento perpendicular e negativas com a clorofila$a(-0,44)$, nitrato $(-0,54)$ e fosfato $(-0,31)$. O vento perpendicular apresentou correlação positiva com a temperatura de fundo e o nitrito, e correlação negativa com a clorofila- $a$. As maiores correlações registradas entre as variáveis obtidas in situ foram as da temperatura de fundo com a clorofila- $a(-0,54)$, o nitrato $(-0,65)$ e o fosfato $(-0,53)$. A clorofila- $a$ também apresentou correlação positiva com nitrato e o fosfato. $\mathrm{O}$ nitrato teve correlação com o fosfato $(0,50)$ e o nitrito com o fosfato.

Tabela 1: Correlação simples entre os ventos, distância da $C B$, temperatura de fundo e as variáveis bioquímicas integradas na coluna de água. Os valores significativos estão destacados em negrito $(p<0,05 ; N=110)$. Valor-p (azul) e coeficiente de correlação (preto).

\begin{tabular}{|c|c|c|c|c|c|c|c|c|c|c|}
\hline & CB & $\begin{array}{c}\text { Vento } \\
\text { paralelo }\end{array}$ & $\begin{array}{c}\text { Vento } \\
\text { perpendic } \\
\text { ular }\end{array}$ & $\begin{array}{l}\text { Temperatura } \\
\text { fundo }\end{array}$ & Clorofila & Nitrato & Fosfato & Nitrito & Silicato & Amônia \\
\hline Distância CB & & 0,0302 & 0,2018 & 0,5569 & 0,0612 & 0,1015 & 0,0194 & 0,9059 & 0,6107 & 0,4622 \\
\hline Vento paralelo & $-0,21$ & & 0,0049 & 0,0000 & 0,0000 & 0,0000 & 0,0012 & 0,5953 & 0,8438 & 0,3957 \\
\hline $\begin{array}{l}\text { Vento } \\
\text { perpendicular }\end{array}$ & $-0,12$ & 0,27 & & 0,0449 & 0,0069 & 0,1722 & 0,9941 & $\begin{array}{r}0,019 \\
2\end{array}$ & 0,6429 & 0,9848 \\
\hline $\begin{array}{l}\text { Temperatura } \\
\text { fundo }\end{array}$ & $-0,06$ & 0,70 & 0,19 & & 0,0000 & 0,0000 & 0,0000 & 0,1173 & 0,0607 & 0,8944 \\
\hline Clorofila & 0,18 & $-0,44$ & $-0,26$ & $-0,54$ & & 0,0000 & 0,0000 & 0,9330 & 0,2939 & 0,9871 \\
\hline Nitrato & 0,16 & $-0,54$ & $-0,13$ & $-0,65$ & 0,52 & & 0,0000 & 0,2092 & 0,3034 & 0,0752 \\
\hline Fosfato & 0,22 & $-0,31$ & 0,00 & $-0,53$ & 0,40 & 0,50 & & $\begin{array}{r}0,001 \\
0\end{array}$ & 0,1316 & 0,4331 \\
\hline Nitrito & $-0,01$ & 0,05 & 0,22 & $-0,15$ & 0,01 & 0,12 & 0,31 & & 0,5530 & 0,4434 \\
\hline Silicato & 0,05 & 0,02 & $-0,04$ & 0,18 & $-0,10$ & 0,10 & 0,14 & $-0,06$ & & 0,5932 \\
\hline Amônia & $-0,07$ & $-0,08$ & 0,00 & 0,01 & 0,00 & $-0,17$ & $-0,08$ & $-0,07$ & $-0,05$ & \\
\hline
\end{tabular}




\section{Análise REDFIT}

\section{Campo de ventos}

No espectro dos ventos com filtro de 50 dias as altas frequências foram minimizadas, mas, ainda foi possível observar frequências maiores que 50 dias (Figura 24). No vento paralelo à costa, independentemente do filtro utilizado, o período de 365 dias teve a potência mais elevada. No entanto, parte da variabilidade foi registrada em escalas menores que 10 dias, como pode ser verificado no espectro com filtro de 2 dias, onde as frequências significativas estão pouco definidas. Os períodos de 30 e 77 dias também foram significativos com os dois filtros. As frequências referentes ao período de 185 e 209 dias foram significativas para o espectro com filtro de 2 dias.
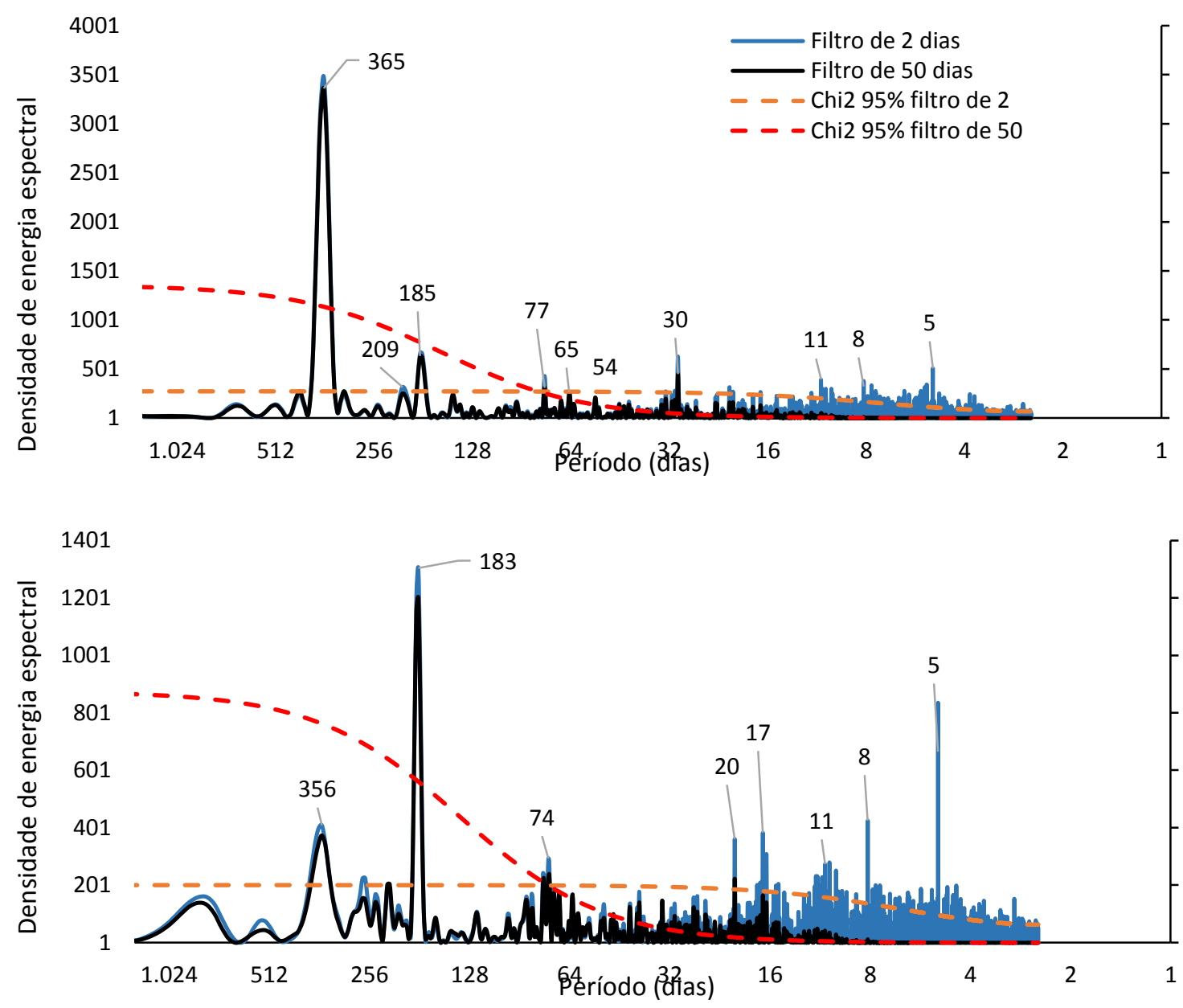

Figura 24: Diagrama de densidade espectral dos ventos paralelo (gráfico superior) e perpendicular gráfico inferior). As linhas tracejadas indicam os níveis de significância $(p=0,05)$. Os períodos significativos são indicados. 
O vento perpendicular tem como principal período 183 dias, o que equivale à metade do principal período do vento paralelo. O ciclo sazonal foi significativo apenas com o filtro de 2 dias. Assim como no vento paralelo, as altas frequências contêm parte da variabilidade dos dados. Os resultados obtidos evidenciam a presença de frequências comuns em períodos de 5, 8 e 11 dias, tanto no vento paralelo quanto no vento perpendicular. Mas, também foram registradas frequências significativas próximas ao encontrado no vento paralelo em 74 dias.

Os resultados obtidos não permitiram identificar o ciclo sazonal na distância da $\mathrm{CB}$, porém, evidenciaram que o período mais energético foi de 246 dias e o ciclo mais longo de 3449 dias, o qual equivale a 9,5 anos. Foi possível verificar a existência de picos próximos aos registrados nos ventos de 66, 79 e 88 dias.

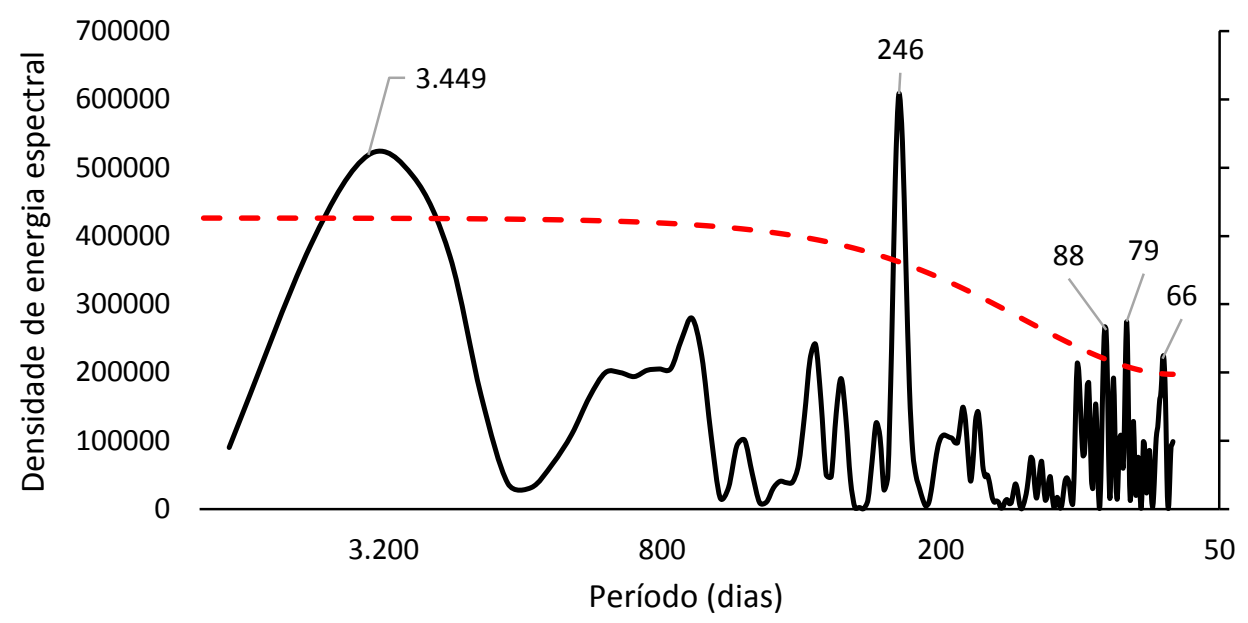

Figura 25: Diagrama de densidade espectral da distância da CB. A linha tracejada indica o nível de significância $(p=0,05)$. Os períodos significativos são indicados.

As temperaturas de superfície e de fundo apresentaram um forte sinal sazonal. $\mathrm{Na}$ temperatura de fundo outras frequências com elevada variância foram equivalentes às de 86, 122 e 137 dias. Ciclos comuns aos dados de temperatura de superfície e de fundo ocorreram em 65, 71, 74 e 78 dias. 


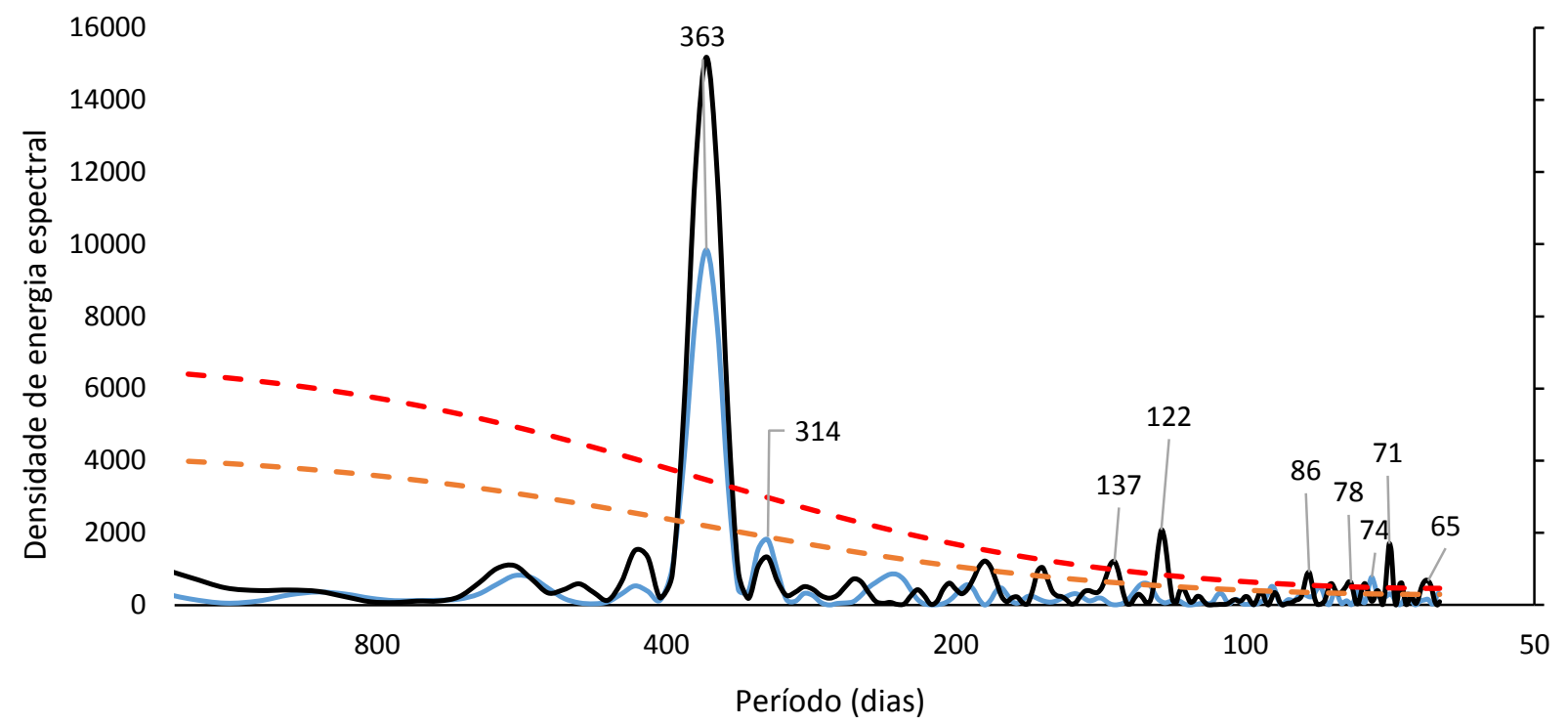

Figura 26: Diagrama de densidade espectral das temperaturas de superfície (azul) e fundo (preto). As linhas tracejadas indicam os níveis de significância $(p=0,05)$. Os períodos significativos são indicados.

O ciclo mais evidente da série de nitrato e o fosfato integrados na coluna foi de 363 dias, enquanto o fosfato teve um ciclo ligeiramente menor, de 321 dias. Novamente ocorrem ciclos semelhantes aos observados anteriormente, com 66, 75, 77, 135 e 138 dias. Outras frequências significativas ocorreram associadas aos ciclos de 93 e 97 dias nos dados integrados de nitrato e aos de 86 e 110 dias nos de fosfato integrado.
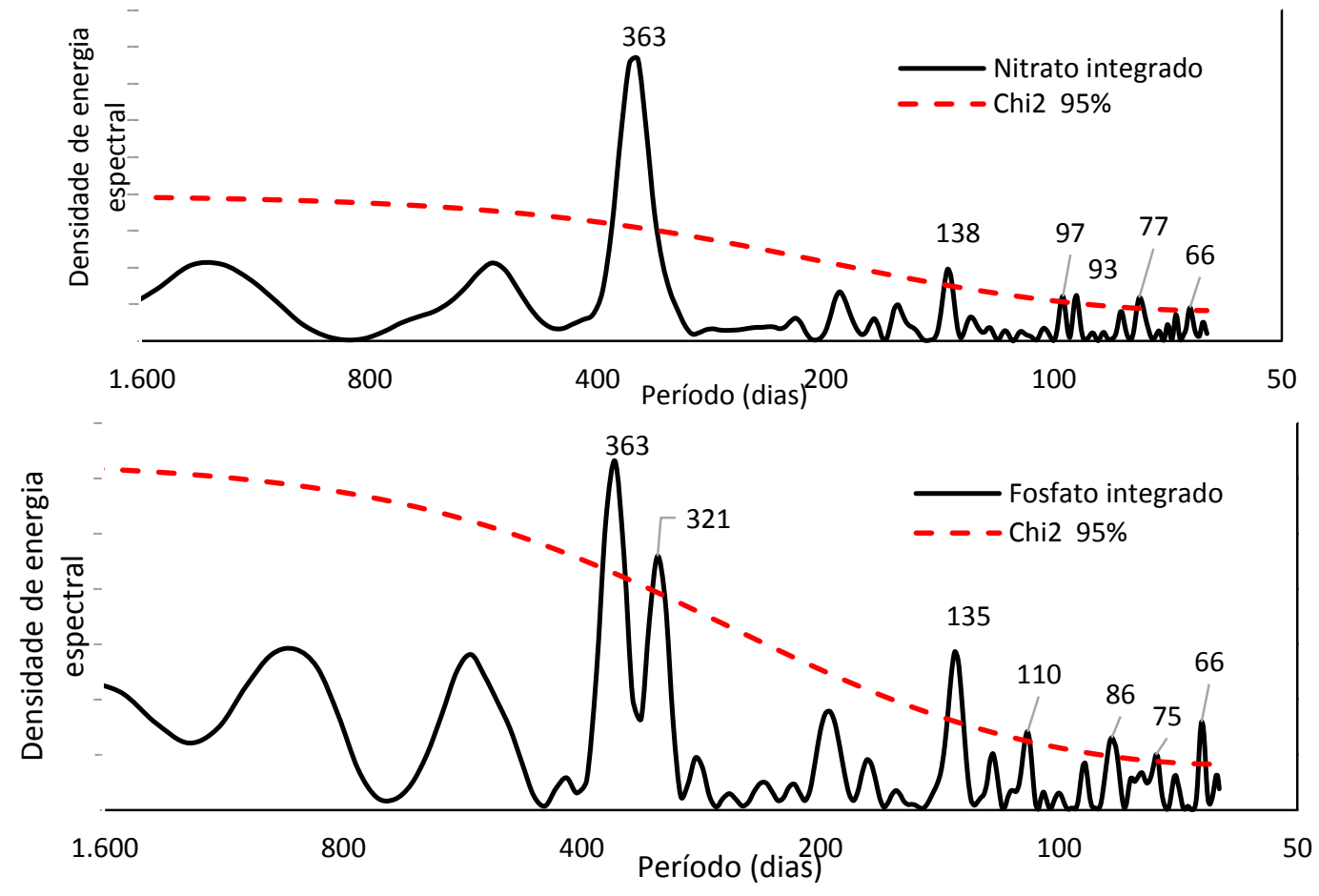

Figura 27: Diagrama de densidade espectral do nitrato (superior) e do fosfato (inferior). As linhas tracejadas indicam os níveis de significância $(p=0,05)$. Os períodos significativos são indicado.. 
A clorofila- $a$ seguiu o mesmo padrão da temperatura, do nitrato e do sendo o ciclo mais energético o de 363 dias. Contudo, houve um ciclo de 690 dias, não observado nos outros espectros. Os ciclos de 65, 71, 121 e 139 dias foram muito semelhantes aos registrados na temperatura, no nitrato e fosfato.

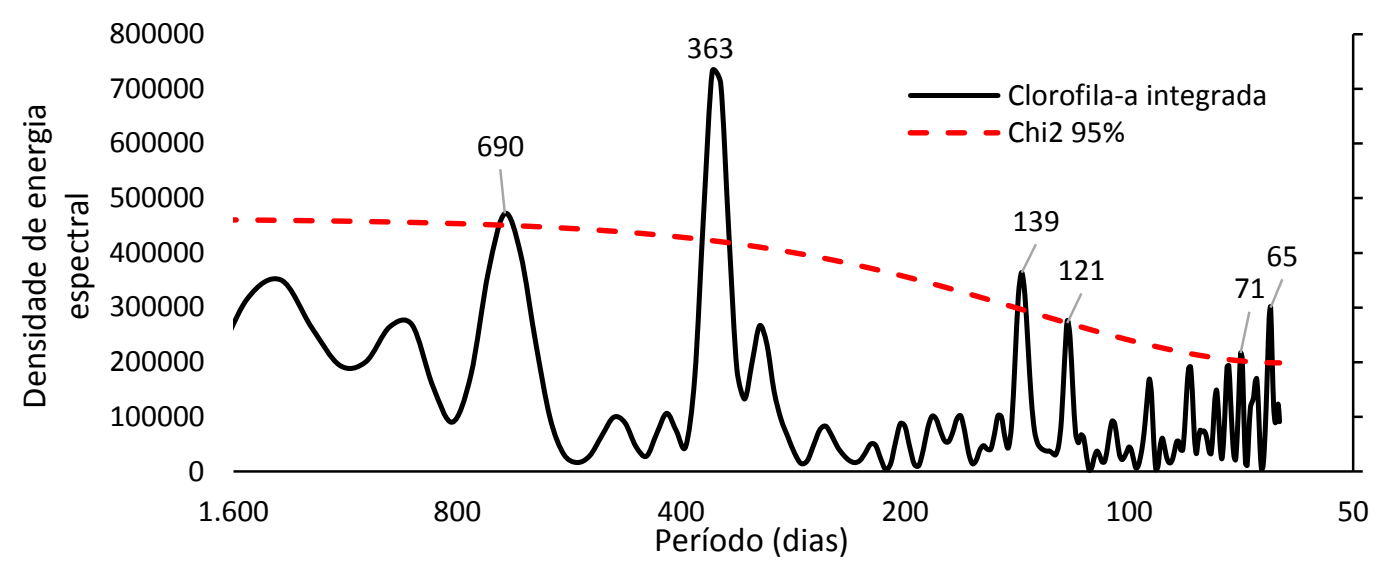

Figura 28: Diagrama de densidade espectral da série de clorofila-a obtida in situ ao largo de Ubatuba, Estado de São Paulo. A linha tracejada indica o nível de significância $(p=0,05)$. Os períodos significativos são indicados.

\section{Análise Wavelet}

De forma semelhante ao observado na análise REDFIT, o vento paralelo também teve como principal período o ciclo sazonal (Figura 29). Porém, a análise Wavelet identificou uma extensa banda de frequências, com ciclos que variam entre 250 e 400 dias. Verificou-se, também, o aumento das frequências nos anos de 2007 e 2011 para ciclos de 130 a 250 dias, e que a banda de frequências sazonal ficou mais estreita em 2010. As frequências mais altas ocorreram com ciclos de 60 a 100 dias em momentos específicos da série, como aconteceu nos anos de 2006 e 2010.

A análise de Wavelet dos ventos perpendiculares apresenta sinal sazonal apenas na metade inicial da série. O predomínio de frequências mais elevadas e o sinal referente a 130 e 250 dias foram recorrentes, apesar de não serem persistentes em toda a série. Ciclos mais curtos, entre 60 e 100 dias, foram mais pronunciados que os dos ventos paralelos. Os resultados obtidos evidenciaram, também, a presença de ciclos significativos na banda entre 60 e 100 dias em 2005, 2010 e 2011. 

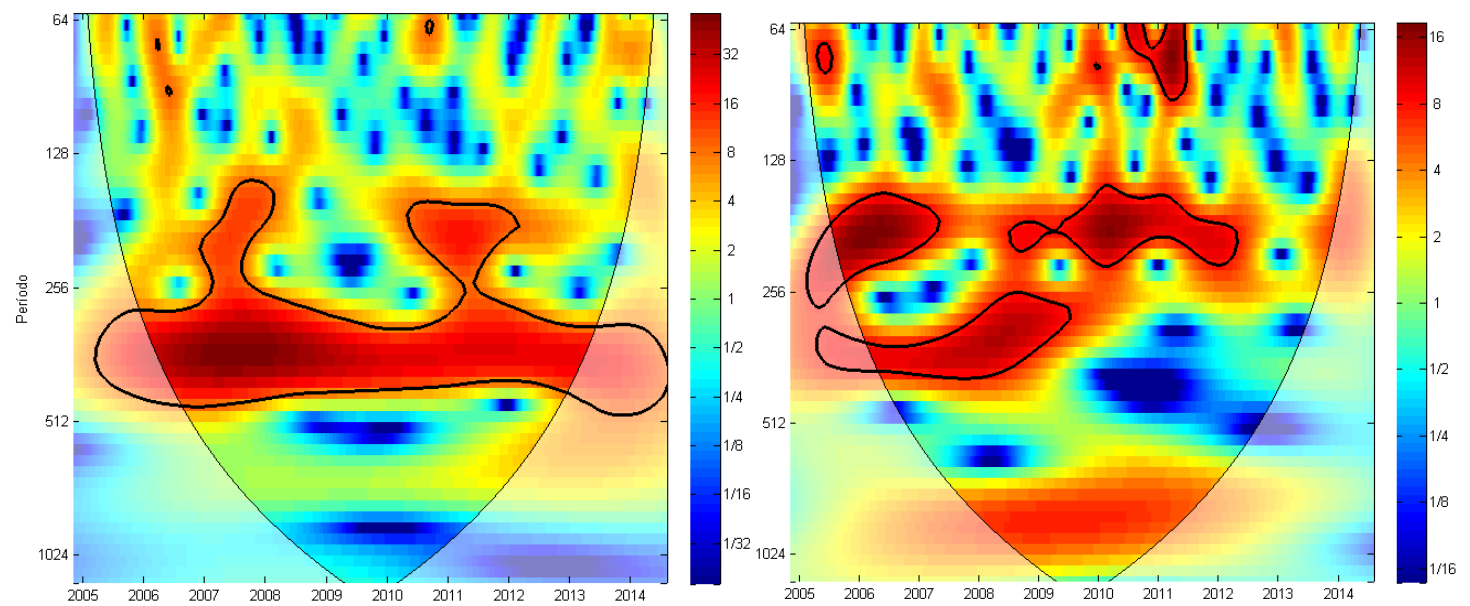

Figura 29: Diagrama da TWC dos ventos paralelo (esquerda) e perpendicular (direita) à costa obtidos no período de dezembro de 2004 e abril de 2014 ao largo de Ubatuba, Estado de São Paulo. A área interna ao cone esbranquiçado delimita a região de significância. Os contornos indicam os valores significativos $(p<0,05)$.

A distância da CB não apresentou ciclo sazonal significativo ao longo da série (Figura 30), sendo registrados valores significativos esparsos no diagrama espaço tempofrequência. No período de 2011 a 2012 ocorreram ciclos em diversas frequências entre 64 e 250 dias, ciclos menores como os de 200 dias nos anos de 2009 e 2013, entre 100 e 120 dias no final de 2009, bem como de 60 a 100 dias em 2006 e 2008. Valores marginalmente significativos com períodos entre 500 e 1000 dias também foram registrados.

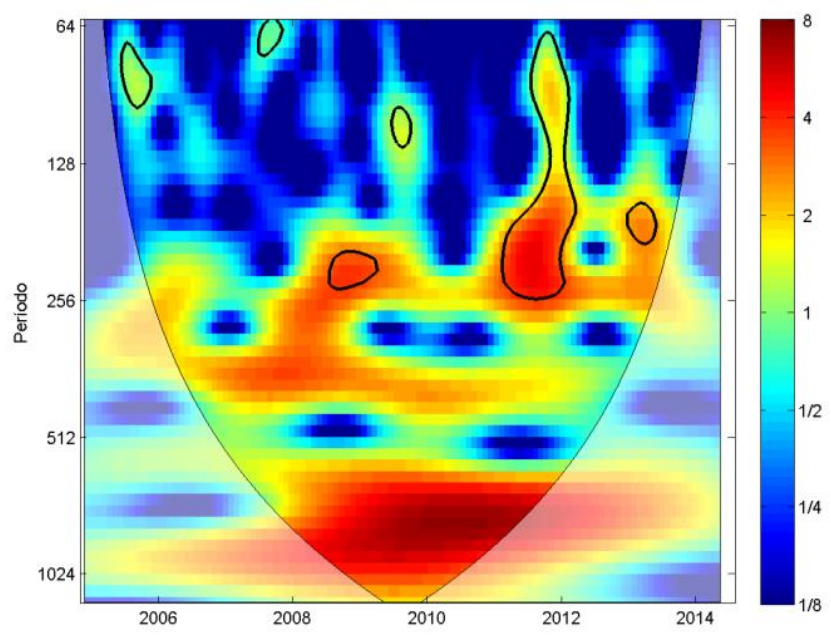

Figura 30: Diagrama da TWC da distância da CB referente ao período de dezembro de 2004 a abril de 2014, ao largo de Ubatuba, Estado de São Paulo. A área interna ao cone esbranquiçado delimita a região de significância. Os contornos indicam os valores significativos $(p<0,05)$. 
O ciclo sazonal da temperatura obtida in situ ao largo de Ubatuba, Estado de São Paulo, é o principal padrão observado (Figura 31). Ao longo da série as mudanças deste padrão foram poucas, com exceção dos anos de 2009 e 2010, quando parte da variabilidade teve periodicidade de 100 a 200 dias e a banda das frequências sazonais ficou mais estreita. Ciclos mais curtos como os de 70 dias (2008), 130 dias (2012) e 70 a 130 dias (2014) também foram registrados no presente estudo.

O nitrato teve um ciclo definido de 100 dias no ano de 2008, apresentando ciclo sazonal somente a partir de 2010. Os resultados permitiram identificar a presença de uma extensa banda de frequências significativas com períodos que variam de 70 a 230 dias, no ano de 2011, e um ciclo de 70 dias em 2014.
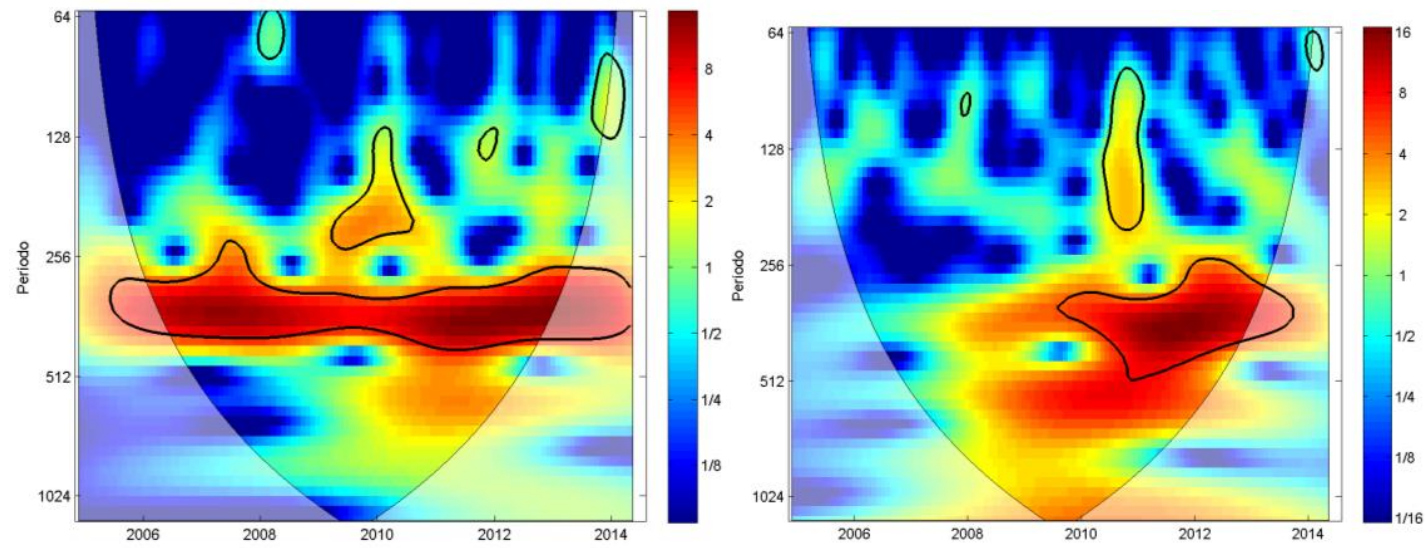

Figura 31: Diagrama da TWC da temperatura (direita) e nitrato integrado (esquerda) coletados in situ no período de dezembro de 2004 a abril de 2014, ao largo de Ubatuba, Estado de São Paulo. A área interna ao cone esbranquiçado delimita a região de significância. Os contornos indicam os valores significativos $(p<0,05)$.

Os resultados mostraram que nos diagramas de TWC do fosfato e da clorofila- $a$ obtidos in situ, o sinal sazonal ocorreu entre o final de 2011 e no ano de 2012 (Figura 32). Os ciclos mais curtos também apresentaram coerência no espaço tempo-frequência com o ciclo de 130 dias em 2009 e de 60 a 100 dias entre 2011 e 2012. Os ciclos mais curtos apresentaram coerência no espaço tempo-frequência, com o ciclo de 130 dias em 2009 e ciclos de 60 a 100 dias entre os anos de 2011 e 2012. No TWC do fosfato verificou-se a presença de uma ampla banda de frequências em 2008, com ciclos variando entre 60 e 150 dias. O mesmo aconteceu com a clorofila- $a$ no ano de 2007. 

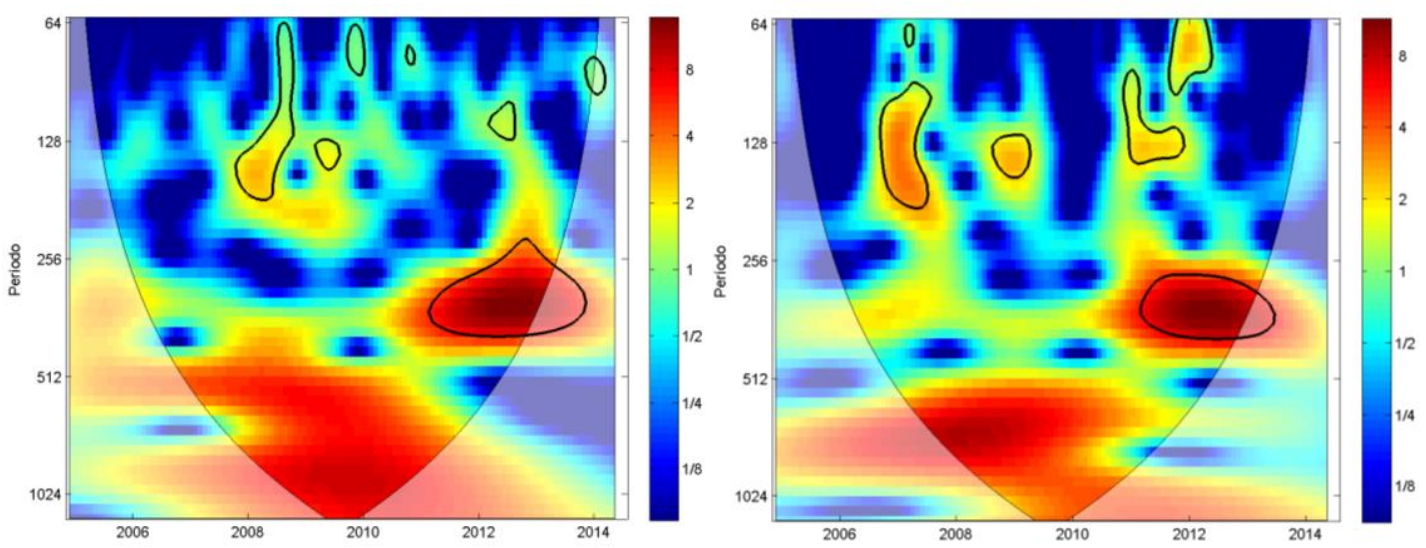

Figura 32: Diagrama da TWC do fosfato integrado (esquerda) e clorofila-a integrada (direita) coletados in situ no período de dezembro de 2004 a abril de 2014, ao largo de Ubatuba, Estado de São Paulo. A área interna ao cone esbranquiçado delimita a região de significância. Os contornos indicam os valores significativos $(p<0,05)$.

As análises de WTX e WC mostraram que o vento paralelo e a temperatura estão em fase com relação ao ciclo sazonal, e a coerência das potencias em altas frequências associadas a ciclos de 60 a 100 dias. Os resultados evidenciam que houve inversão das fases nesta banda de frequências nos anos de 2009, 2010 e 2012. Um estreitamento da banda sazonal no diagrama de WTX e coerência no período de 100 dias, com diferenças em relação às fases, foram registrados em 2010, bem como a diminuição progressiva das frequências coerentes de 200 a 130 dias, com atraso de fases constantes em 2012.
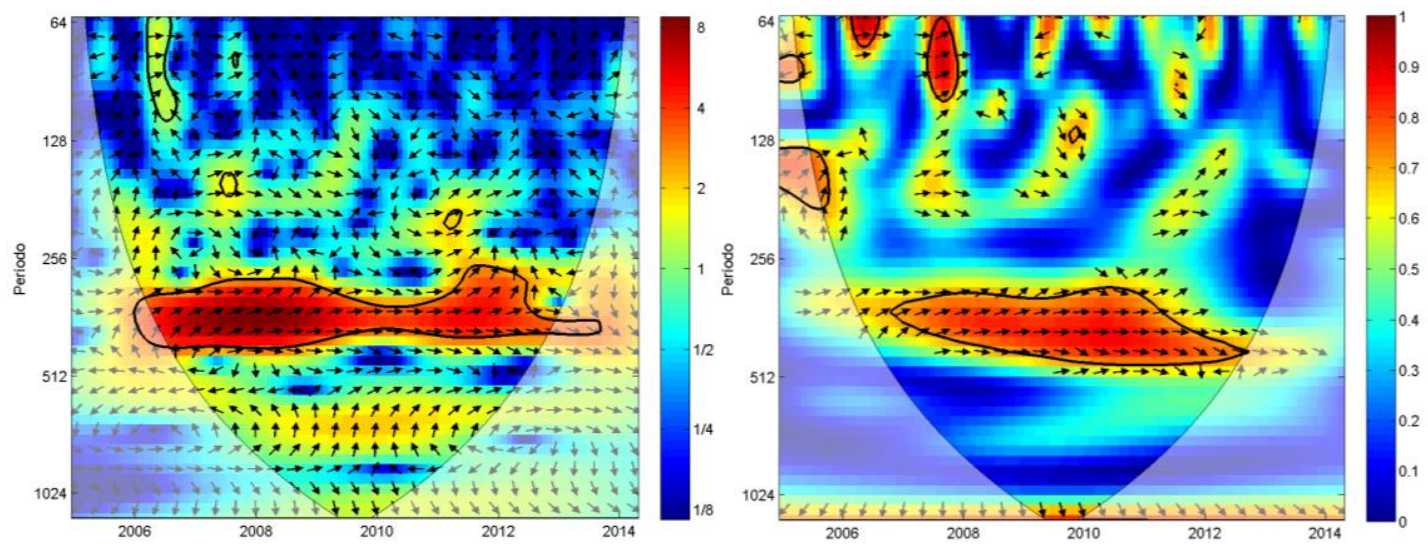

Figura 33: Diagrama da TWX (esquerda) e WC (direita) do vento paralelo à costa e temperatura obtida in situ ao largo de Ubatuba, Estado de São Paulo, no período compreendido entre 2004 a 2014. A área interna ao cone esbranquiçado delimita a região de significância. Os contornos indicam os valores significativos $(p<0,05)$.

O diagrama de TWX entre o vento paralelo e o nitrato foi semelhante ao diagrama TWX do vento paralelo e a temperatura, exceto pela diferença de fases. O sinal sazonal pode ser observado com fases invertidas e ser identificado no WC, embora a frequência 
tenha diminuindo ao longo da série. Os resultados mostram a coerência das potências entre os ciclos de 100 a 250 dias, no período de 2010 a 2012, com diferenças de $270^{\circ}$.
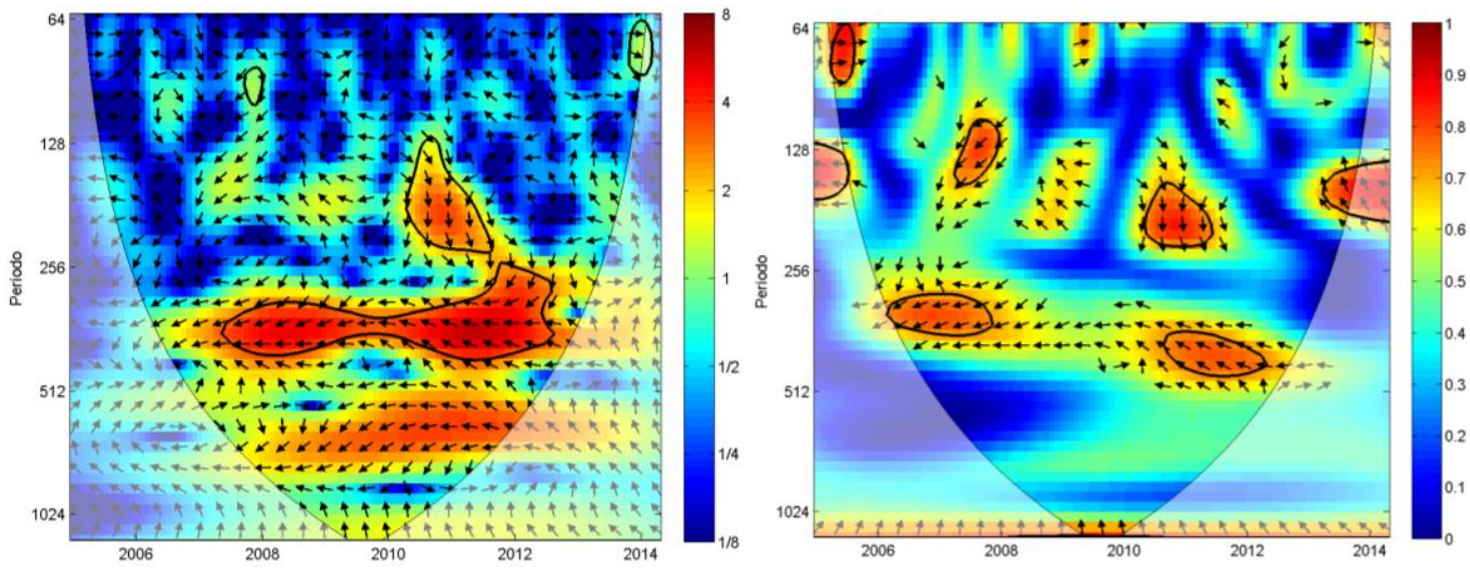

Figura 34: Diagrama da TWX (esquerda) e WC (direita) do vento paralelo à costa e nitrato integrado obtido in situ ao largo de Ubatuba, Estado de São Paulo, no período compreendido entre 2004 a 2014. A área interna ao cone esbranquiçado delimita a região de significância. Os contornos indicam os valores significativos $(p<0,05)$.

O diagrama de TWX do fosfato foi semelhante ao do nitrato, porém com ciclo sazonal marcado apenas em 2008 e 2012. O diagrama de WC mostrou fases opostas em relação ao sinal sazonal, apesar de não serem significativos. Os dados mostraram a presença de ciclos menores esparsos por toda a série, porém sem padrão em relação as fases.
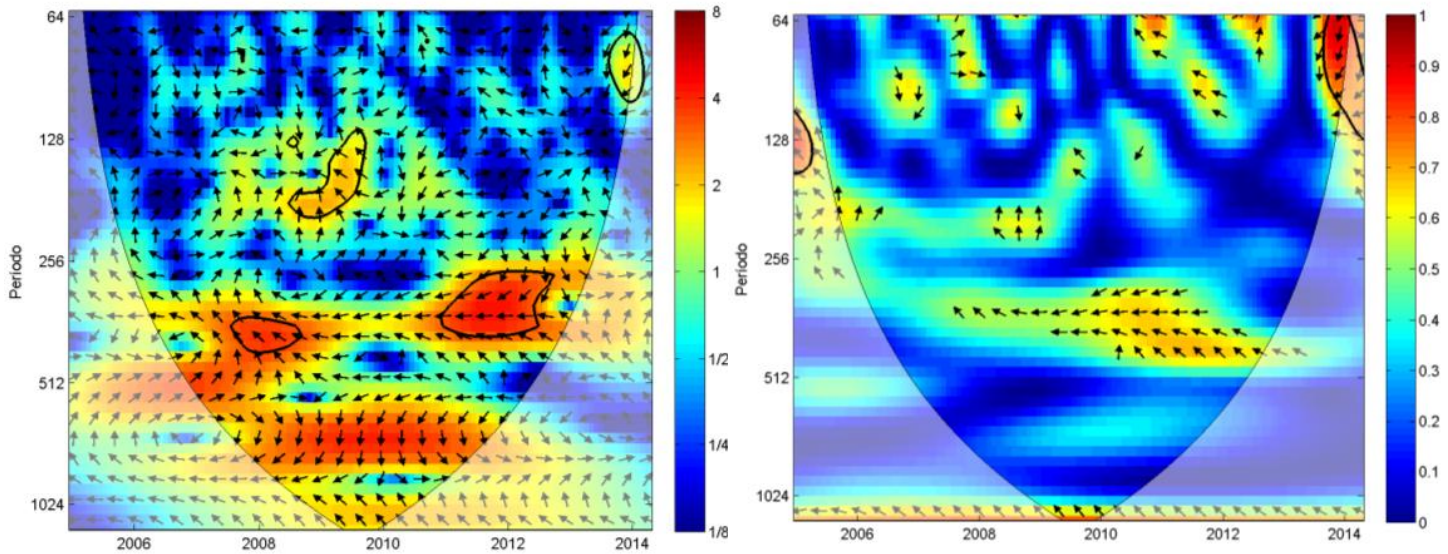

Figura 35: Diagrama da TWX (esquerda) e WC (direita) do vento paralelo à costa e o fosfato integrado obtido in situ ao largo de Ubatuba, Estado de São Paulo, no período compreendido entre 2004 a 2014. A área interna ao cone esbranquiçado delimita a região de significância. Os contornos indicam os valores significativos $(p<0,05)$. 
A clorofila- $a$ e o vento paralelo tiveram coerência das potencias e fases em relação ao sinal sazonal em períodos específicos no tempo, sendo que as fases se mantiveram opostas nesta escala temporal. Os resultados evidenciaram a existência de coerência entre as potencias em frequências referentes a 700 dias, com diferenças entre as fases constante, e que em regiões significativas do espaço tempo-frequência os sinais estão aproximadamente em anti-fase, com exceção das altas frequências. No diagrama de WC, em 2008 houve uma ampla banda de frequências coerentes em anti-fase.
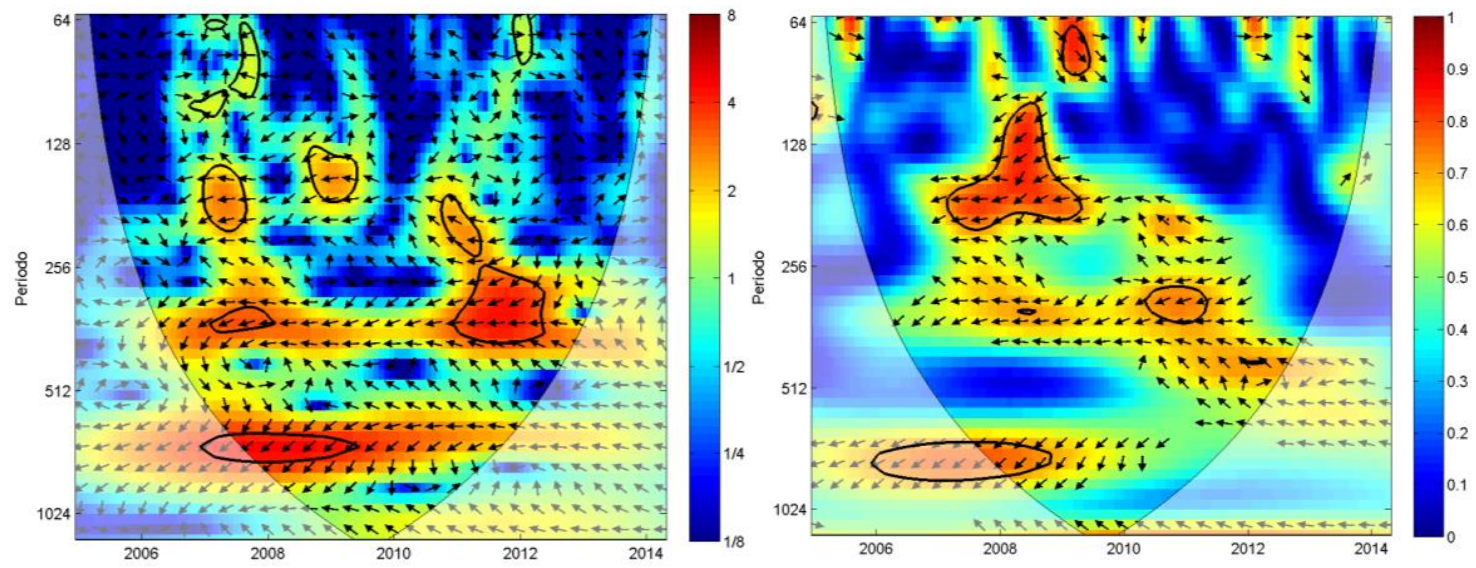

Figura 36: Diagrama da TWX (esquerda) e WC (direita) do vento paralelo à costa e a clorofila-a integrada obtida in situ ao largo de Ubatuba, Estado de São Paulo, no período compreendido entre 2004 a 2014. A área interna ao cone esbranquiçado delimita a região de significância. Os contornos indicam os valores significativos $(p<0,05)$.

O diagrama de TWX da distância da CB e temperatura mostrou coerência entre as potências dos sinais sazonais, apesar da fase não ser constante já que passou de $0^{\circ}$ para $180^{\circ}$ a partir de 2010. No início da série, as altas frequências foram recorrentes, mas descaíram progressivamente até a metade da série e aumentaram novamente, até final. No diagrama de WC, a variabilidade de alta frequência foi registrada em toda a série. 

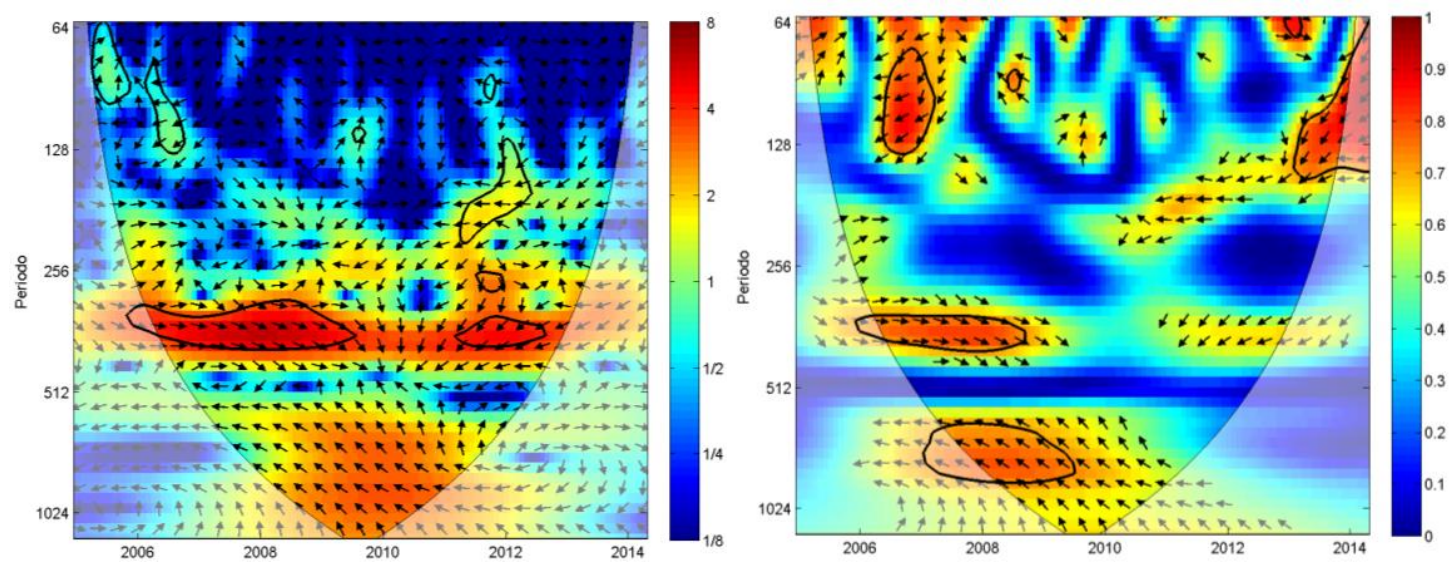

Figura 37: Diagrama da TWX (esquerda) e WC (direita) da distância da CB e da temperatura obtida in situ ao largo de Ubatuba, Estado de São Paulo, no período compreendido entre 2004 a 2014. A área interna ao cone esbranquiçado delimita a região de significância. Os contornos indicam os valores significativos ( $p<0,05)$.

Os resultados obtidos evidenciaram que no sinal sazonal do nitrato também houve inversão de fases a partir de 2010, porém, com sentido oposto ao da temperatura. O diagrama de WC mostrou coerência em escalas menores que 150 dias em toda a série, com alternância de direção das fases, enquanto o diagrama de TWX a coerência entre as variabilidades em diferentes frequências, sem padrão de fases, entre os anos de 2011 e 2012.
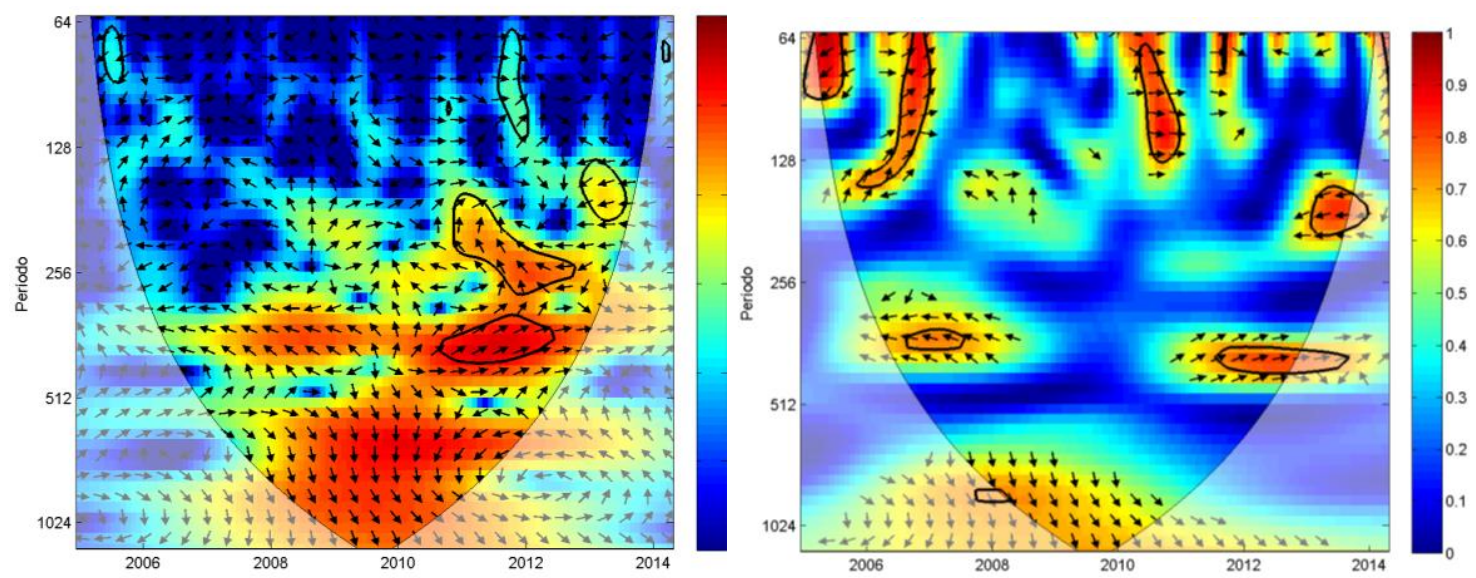

Figura 38: Diagrama da TWX (esquerda) e WC (direita) da distância da CB e nitrato obtido in situ ao largo de Ubatuba, Estado de São Paulo, no período compreendido entre 2004 a 2014. A área interna ao cone esbranquiçado delimita a região de significância. Os contornos indicam os valores significativos $(p<0,05)$.

Não foi observada a existência de coerência entre o sinal sazonal do vento paralelo e o fosfato no diagrama de TWX, em contraposição houve coerência entre as potencias em 2010, com ciclo de aproximadamente 700 dias. O diagrama de WC revelou a presença 
de altas frequências com fases alternantes e uma ampla região de coerência em baixas frequências, com atraso entre as fases.
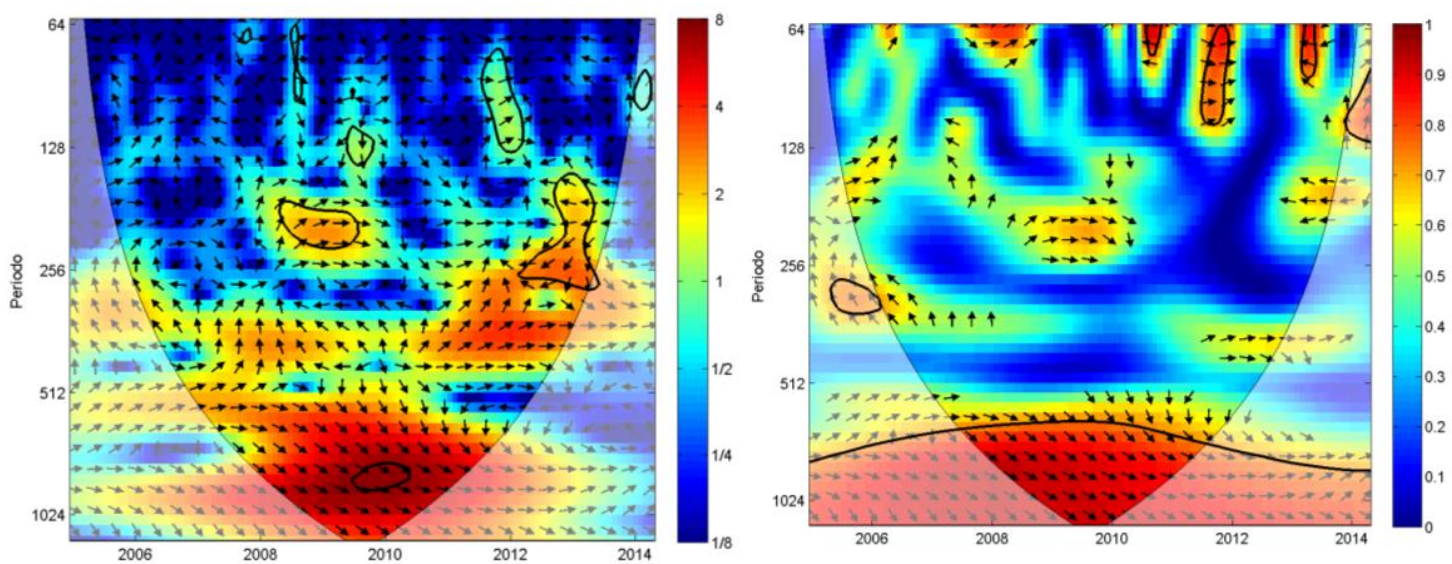

Figura 39: Diagrama da TWX (esquerda) e WC (direita) da distância da CB e fosfato obtido in situ ao largo de Ubatuba, Estado de São Paulo, no período compreendido entre 2004 a 2014. A área interna ao cone esbranquiçado delimita a região de significância. Os contornos indicam os valores significativos ( $p<0,05)$.

A clorofila- $a$ e a distância da CB tiveram pouca coerência em relação a TWX e a WC. No entanto, pode-se observar que em 2012 houve variabilidades em comum entre os períodos de 60 e 200 dias, aproximadamente em fase. No diagrama de WC é possível observar o mesmo efeito da mudança da direção de fases a partir de 2010.
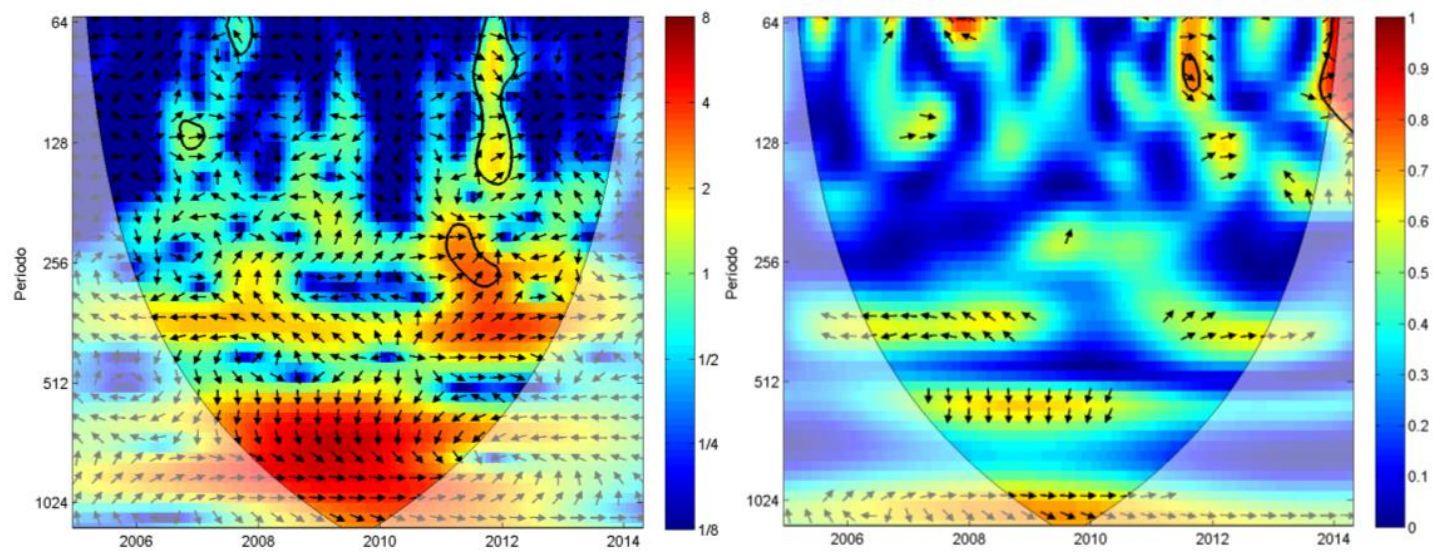

Figura 40: Diagrama da TWX (esquerda) e WC (direita) da distância da CB e clorofila-a obtida in situ ao largo de Ubatuba, Estado de São Paulo, no período compreendido entre 2004 a 2014. A área interna ao cone esbranquiçado delimita a região de significância. Os contornos indicam os valores significativos $(p<0,05)$. 


\section{Discussão}

\section{Influência do campo de ventos}

Os mapas de correção entre o campo de ventos inicial com a temperatura de fundo revelaram a presença de uma ampla área de correlações significativas, indicando que ambas as séries têm variabilidades associadas à mesma escala de tempo. Assim como a série de temperatura, o campo de ventos de larga escala tem forte componente sazonal (Satyamurty et al., 1998), por isso regiões distantes podem ter fortes correlações mesmo não estando associadas, necessariamente, às interações físicas entre as variáveis. As correlações foram mais intensas nos casos em que as variáveis estiveram em fase (correlação positiva) ou com fase invertida (correlação negativa).

Analisando a climatologia da grade de ventos selecionada, houve predomínio de ventos de nordeste ao longo dos anos, corroborando com a climatologia mensal de 45 anos da PCSE de Da Silva et al., 1994. Resultados do presente trabalho mostram que os ventos paralelos à costa têm correlação negativa com a temperatura de fundo, indicando que os ventos predominantes de nordeste, negativos em relação à componente paralela à costa, estão relacionados à queda da temperatura de fundo. Estes ventos podem explicar 49\% da variabilidade da temperatura. Segundo Castro et al. (2006), as principais forçantes hidrográficas da PCSE são os ventos locais e remotos em escalas sazonal e sinóptica. Ventos suavizados por filtros mais abrangentes melhoram a correlação entre vento e temperatura, indicando a importância do vento remoto e que sinal de alta frequência dos ventos pode interferir nas correlações.

A coerência entre o transporte de Ekman calculado pela tensão de cisalhamento do vento e a temperatura de fundo em diversos sistemas costeiros foi observada por autores como de Szoeke e Richman (1984), Mitchum e Clarke (1986), Lentz (1995, 2001), Samelson (1997), Austin e Lentz (2002). Austin e Barth (2002) propuseram uma medida de intensidade de ressurgência baseada na posição da picnoclina permanente de diversos transectos ao longo da plataforma de Newport, Oregon, e, comparando com o índice de ressurgência baseado na tensão de cisalhamento do vento na plataforma, houve forte correlação. Essa análise revelou, também, o tempo de relaxamento de 8 dias para que se atinja o equilíbrio geostrófico. Dessa forma, as características hidrográficas coerentes com o transporte de Ekman estão relacionadas ao vento dos 8 dias anteriores ao evento 
observado. A máxima correlação obtida no presente trabalho entre o vento paralelo e a temperatura foi com o atraso de 15 dias.

O vento de nordeste pode gerar dois tipos de ressurgência, uma ressurgência local devido ao transporte de Ekman, e outra remota, provocada pelo transporte barotrópico de águas ressurgidas ao longo da costa. Cerda e Castro (2014) descrevem que a advecção remota da ACAS, transportada ao longo da costa para sudoeste, ocorre no verão, inverno e primavera, e que esta advecção está relacionada à uma via de intrusão primária localizada ao largo de Cabo Frio. Lorenzetti e Gaeta (1996), analisando imagens de satélite de TSM concluíram que na primavera, 10 dias após um fenômeno de ressurgência em Cabo Frio, a ACAS chegou a percorrer 300 a 400 km, atingiu a Ilha de São Sebastião. Considerando o ponto de coleta ao largo de Ubatuba, como o mecanismo de transporte é barotrópico, espera-se que a ressurgência remota cause uma anomalia negativa de temperatura em toda a coluna de água. As correlações obtidas mostram coerência entre o vento paralelo e a temperatura em toda coluna de água, apenas na primavera, indicando que a ressurgência remota pode ser o processo dominante ao largo de Ubatuba nesta estação.

Carbonel e Valentin (1999), aplicando um modelo físico-biológico, simularam um evento de ressurgência e concluíram que a água advectada ao longo da costa, um dia após a entrada de nutrientes na zona eufótica, apresentou uma floração de fitoplâncton e, que 7 dias após o início da ressurgência, os nutrientes haviam sido consumidos. Isto explicaria porque na primavera a correlação do vento paralelo com a clorofila- $a$ em superfície foi negativa (advecção de biomassa) e a ausência de correlação com o nitrato, que já estaria exaurido. De acordo com Aidar et al. (1993), a ACAS caracteriza-se por elevados valores de fosfato. No presente trabalho esse fosfato justificaria a correlação encontrada entre o vento paralelo e o fosfato.

Cerda e Castro (2014) identificaram uma via secundária de intrusão local ativa na primavera ao largo de Ubatuba. Esta intrusão, ao contrário da remota, introduz nutrientes novos na zona eufótica em direção à costa, favorecendo a correlação entre o vento paralelo e o nitrato, assim como com o fosfato no fundo. No entanto, nos resultados obtidos no presente trabalho, essas correlações ocorreram somente a partir do verão. Em geral, as escalas do fluxo paralelo e perpendicular à costa são muito distintas, o que favorece a dominância de fluxo geostrófico paralelo à costa em escalas de movimento 
planetária (Amor, 2004). Se a região de Cabo Frio (RJ) é a via primária de intrusão e a advecção um processo mais rápido que a ressurgência local, espera-se que o primeiro mecanismo de disponibilização da ACAS ao largo de Ubatuba (SP) seja a intrusão remota na primavera. No verão, houve diminuição da correlação do vento paralelo e a temperatura de fundo e o aumento em profundidades intermediárias. Gaeta et al. (1999), estudando a produção primária da região de Ubatuba, verificaram que no verão os principais fatores que influenciaram a distribuição da biomassa fitoplanctônica foram a intrusão da ACAS, a de passagem sistemas frontais e precipitação, os ventos normais à costa e o vento paralelo à costa. Isto indicaria que pequenas variações no campo de ventos não são suficientes para mudar a posição da ACAS no verão, presente na região desde o final da primavera, e que os sistemas transientes são importantes por que podem provocar distúrbios na profundidade da termoclina, influenciando a distribuição da biomassa fitoplanctônica. Isto sugere que a intrusão local no verão ocorre após a plena intrusão remota de primavera e que os sistemas frontais são mais importantes que o vento de nordeste para explicar a variabilidade da concentração de clorofila- $a$ e nutrientes nesta época do ano.

De acordo com Silva et al (1994), os ventos no outono apresentam intensidades mínimas entre $22^{\circ}$ e $25^{\circ} \mathrm{S}$, também observado no presente trabalho. A diminuição dos ventos de nordeste pode enfraquecem o transporte de Ekman, não sustentando a intrusão da ACAS sobre a plataforma. Segundo Cerda e Castro (2014) o outono se aproxima do estado básico em relação às condições hidrográficas, ou seja, sem forçantes externas de ventos. A dispersão entre vento e temperatura de fundo mostrou que os ventos paralelos de sudoeste, positivos nesta componente, estiveram relacionados às maiores temperaturas registradas ao largo de Ubatuba. Com relação ao nitrato e ao fosfato de fundo, a correlação negativa indica que ventos de sudoeste podem diminuir o fluxo de ACAS para a zona eufótica pela convergência na costa. A correlação positiva com a clorofila- $a$ sugerem que esta convergência na costa é responsável pelo aumento da concentração de clorofila- $a$ na superfície.

Ao largo de Ubatuba, apesar de não ser observada a presença da ACAS no inverno, os ventos de nordeste são persistentes. Satyamurty et al.(1998) concluiram que nas latitudes mais altas, no inverno ocorre diminuição da intensidade de ventos de nordeste e penetração mais recorrente de frentes frias atmosféricas. Por outro lado, embora as frentes sejam comuns nas estações do ano, a frequência de ocorrência varia mensalmente na 
região compreendida e, na região compreendida entre $20^{\circ}$ e $25^{\circ} \mathrm{S}$, ocorrem em média duas a três passagens de sistemas frontais em fevereiro e cinco a seis em outubro (Oliveira, 1986). No presente trabalho, observando-se a convolução entre os ventos paralelos e a temperatura (Figura 17), o aumento da correlação com atraso de 10 e 20 dias pode estar relacionado à influência da passagem de frequentes frias que, de acordo com Cavalcanti e Kousky (2009), na área de estudo tem periodicidade média de uma passagem a cada 12 dias. Estudos realizados por Stech e Lorenzetti (1992) mostraram que a passagem de frentes frias resulta no equilíbrio quase-geostrófico das correntes sobre a plataforma, movendo-se na mesma direção do sistema frontal, e que as oscilações inerciais decorrentes deste distúrbio podem ser amplificadas. Tintoré et al. (1995), estudando os efeitos das oscilações inerciais na costa concluíram que a energia destas ondas é propagada da superfície para o fundo, resultando na quebra da estratificação. Assim, a condição de inverno propicia a passagem dos sistemas frontais, a qual está relacionada ao transporte barotrópico de águas costeiras para norte, convergência pelo transporte de Ekman em direção à costa e a homogeneização da coluna de água.

As incursões da Frente Substropical do Rio da Prata sobre PCSE no inverno, explicariam grande parte da variabilidade observada nesta época do ano. Estudos combinando dados coletados in situ e imagens de satélite mostram que esta frente pôde ser detectada até 23030'S (Campos et al, 1995, 1996a,b). No presente trabalho, no transecto T1 de TSM foi possível observar uma anomalia negativa de TSM no inverno de 2007 (Figura 12) e, analisando a imagem de TSM deste período, a notória intrusão desta frente como pode ser observado na Figura 41. Trabalhos recentes mostram que a variabilidade sazonal desta frente é controlada pela tensão de cisalhamento do vento paralelo à costa e que distribuição da baixa salinidade é mais sensível aos ventos de sudoeste do que à própria descarga fluvial (Piola et al., 2005; Pimenta et al., 2005). Além disso, esta frente é responsável pela introdução de grandes quantidades de silicato e fosfato na plataforma interna e dos nutrientes consumidos pelo fitoplâncton (Ciotti et al.,1995). As correlações do inverno mostraram que os ventos de sudoeste estão associados ao aumento do fosfato de superfície (correlação positiva) e diminuição do nitrato e clorofila- $a$ em toda a coluna de água (correlação negativa), evidenciando a importância da advecção lateral da Frente Substropical do Rio da Prata. 


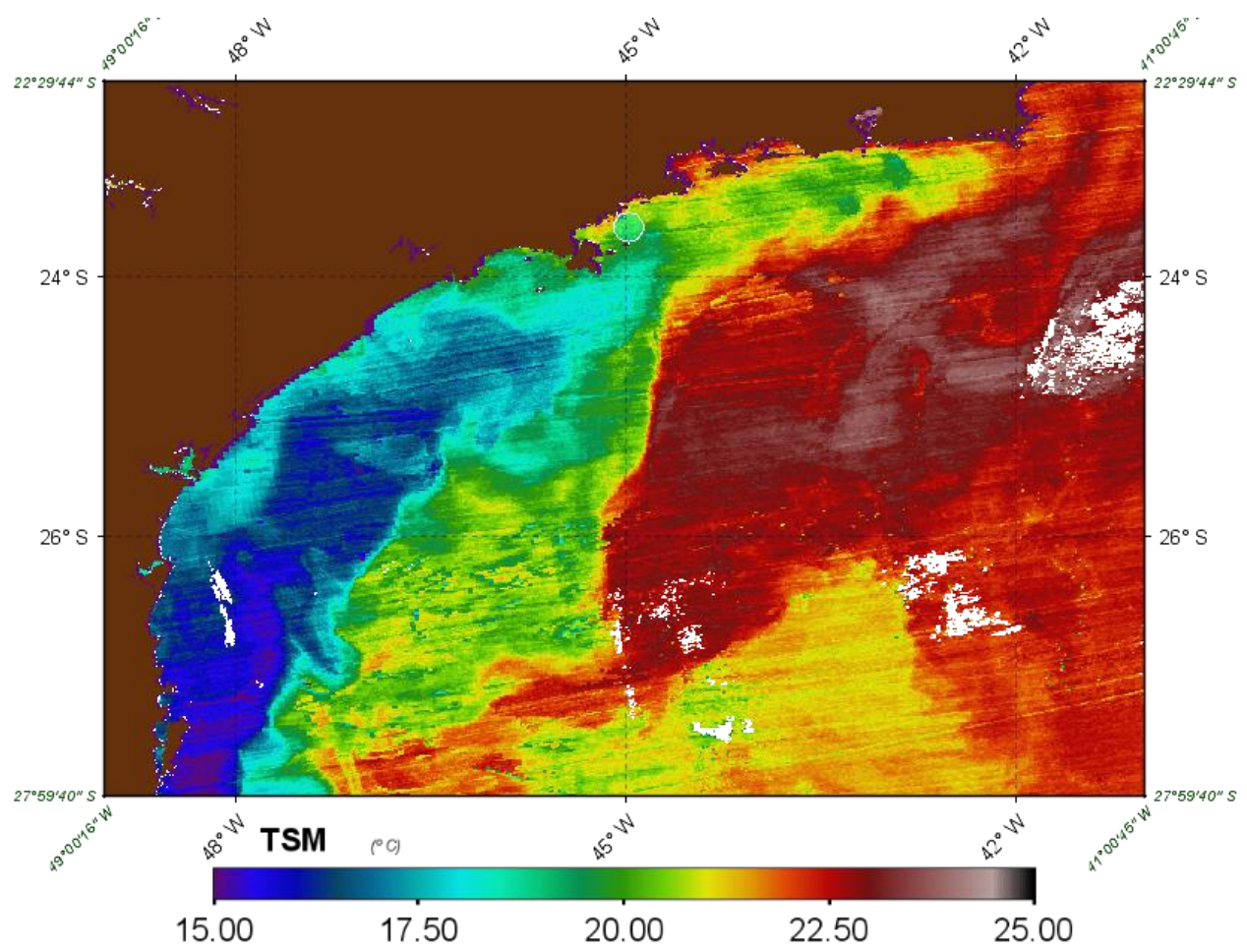

Figura 41: Imagem de TSM de 21 de julho de 2007. Nota-se o deslocamento da Frente Subtropical do Rio da Prata sobre a PCSE.

\section{Influência do meandramento da CB}

Diversos autores mostraram que o meandramento da $\mathrm{CB}$ pode favorecer ressurgências costeiras na Plataforma Sudeste (Campos et al., 1995; Gaeta et al.,, 1999b; Schmid et al., 1995; Campos et al., 2000; Castelão et al., 2004; Calado et al., 2010; Paloczy et al., 2013). De acordo com Campos et al. (1995), na Bacia de Santos (25 S $28^{\circ} \mathrm{S}$ ) o meandramento da CB próximo da quebra da plataforma é um importante mecanismo para a intrusão da ACAS na plataforma continental entre o Rio de Janeiro e Santos. No modelo conceitual apresentado pelos autores, o meandro ciclônico eleva as isotermas na parte anterior e advecta água fria (ACAS) sobre a plataforma. Estudos feitos nas proximidades do Cabo de São Tomé, utilizando-se modelagem numérica, indicam que o meandro quasi-estacionário, recorrente nesta região, pode ser responsável por causar um evento de ressurgência mesmo sem considerar a atuação dos ventos (Calado et al., 2010).

A distância da $\mathrm{CB}$ estaria relacionada ao meandramento da $\mathrm{CB}$, uma vez que quando o meandro se desloca para águas profundas, aumentando a distância da costa, 
tende a meandrar ciclonicamente, Em contraposição, quando se dirige a águas mais rasas, diminuindo essa distância, meandra anticiclonicamente. A distância média da CB registrada no presente trabalho foi $114 \mathrm{~km}$, que corresponde a $260 \mathrm{~m}$ de profundidade. Garfield III (1990) utilizando imagens de satélite de 1982 a 1987 demonstrou que a CB flui sobre a isóbata de $200 \mathrm{~m}$. Stech et al. (2007) analisando 199 imagens de TSM correspondentes aos anos de 2000 e 2001 verificaram que ao largo da Bacia de Santos, na isóbata de $200 \mathrm{~m}$, ocorreu a maior densidade de frentes da CB.

Em geral, houve poucas correlações significativas entre a distância da $\mathrm{CB}$ e as variáveis obtidas in situ ao largo de Ubatuba. No entanto, as correlações com temperatura a $30 \mathrm{~m}$ no verão e a $5 \mathrm{~m}$ na primavera foram negativas e marginalmente significativas, indicando que o aumento da distância pode favorecer o processo de ressurgência. Por outro lado, o aumento da distância também esteve correlacionado com a elevação na concentração de clorofila- $a$ e de nitrato na primavera e no verão, nessas profundidades. O fosfato teve correlação positiva em $20 \mathrm{~m}$ e o fundo no verão e no inverno e, considerando os valores integrados, também esteve correlacionado com a distância da $\mathrm{CB}$, indicando que o fluxo de nutrientes para a plataforma seria influenciado pelo meandramento ciclônico.

$\mathrm{Na}$ literatura, não são encontrados registros sobre o papel que o meandramento anticiclônico cumpre nas trocas de água entre oceano e plataforma na PCSE. Churchill et al. (1986) descreveram a passagem de um vórtice anticiclônico ao largo de Nova Jersey e concluíram que houve advecção de águas de superfície do talude para a plataforma e de águas de fundo da plataforma para o talude. Estes autores mostram também que associado à formação deste vórtice anticiclônico, outro vórtice ciclônico foi formado à frente com cerca de 1/3 da magnitude de seu momento angular. Analisando a imagem referente ao período mais quente da série de TSM, registrado no ano de 2010, que coincide com o ano em que não houve penetração de ACAS no verão, observa-se a presença de um vórtice anticiclônico de grande magnitude ao largo de Ubatuba (Figura 42). A análise da imagem de clorofila- $a$ indica que a água superficial da plataforma foi advectada para regiões oceânicas. Isto por que considerando os dados do T2 a $200 \mathrm{~km}$ do ponto de coleta, as concentrações de clorofila- $a$ no verão foram em média $0,05 \mathrm{mg} / \mathrm{m}^{3}$. Como o movimento anticiclônico é convergente em superfície, espera-se que seja acumulada biomassa fitoplanctônica em superfície advectada a partir da plataforma. 


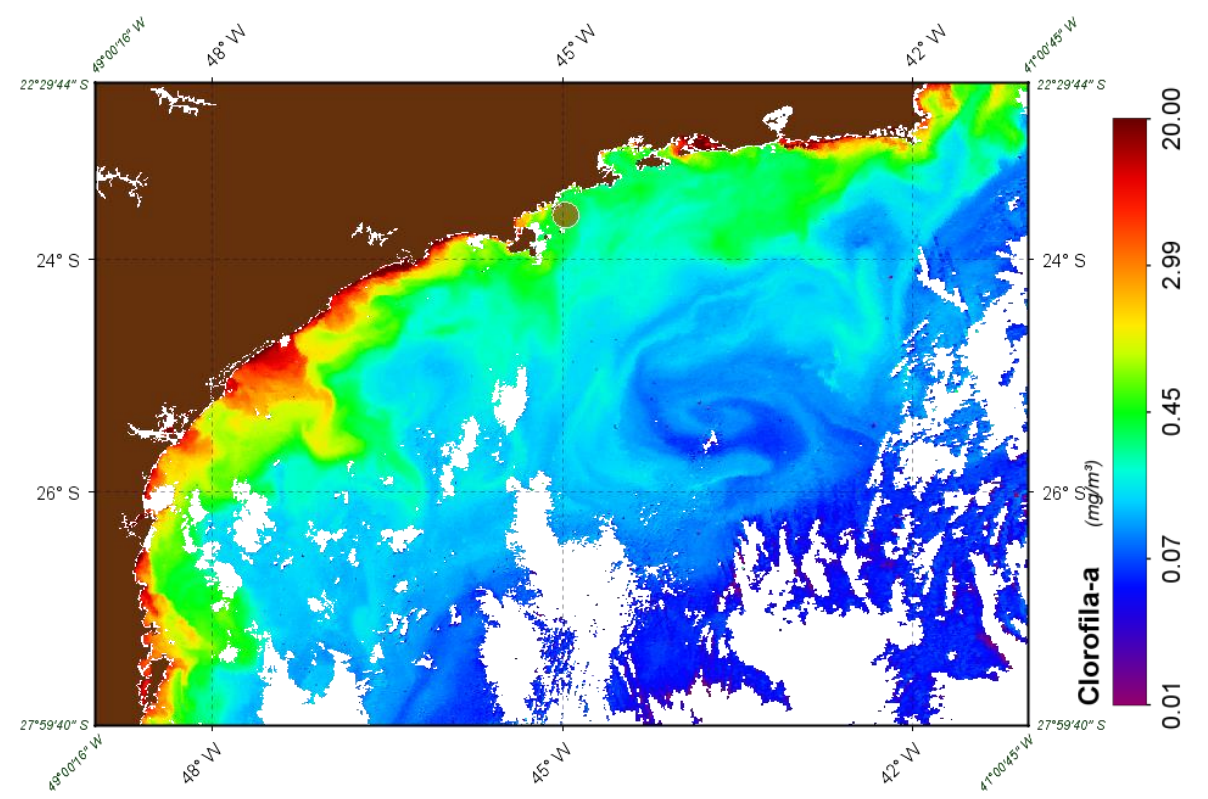

Figura 42: Imagem de CSM de 28 de janeiro de 2010. Nota-se a presença de um vórtice anticiclônico ao largo da PCSE.

Dados de altimetria (cedidos pelo Dr. Paulo Polito, do IOUSP) mostram coerência entre o centro de alta e o vórtice anticiclônico e a ocorrência de vórtices ciclônicos menores associados (Figura 43). É interessante salientar que estes dados não são indicados para análises em regiões com profundidades menores que $1000 \mathrm{~m}$ e que o tempo de aquisição é da ordem de alguns dias, mas, mesmo assim há coerência entre as imagens. De acordo com Churchill et al. (1986), nos dados de altimetria também é possível detectar vórtices ou meandros ciclônicos associados aos anticiclônico. Assim, as altas temperaturas registradas na costa em janeiro de 2010 seriam provocadas pelo recuo da ACAS no fundo e pela advecção de águas oceânicas em superfície. 


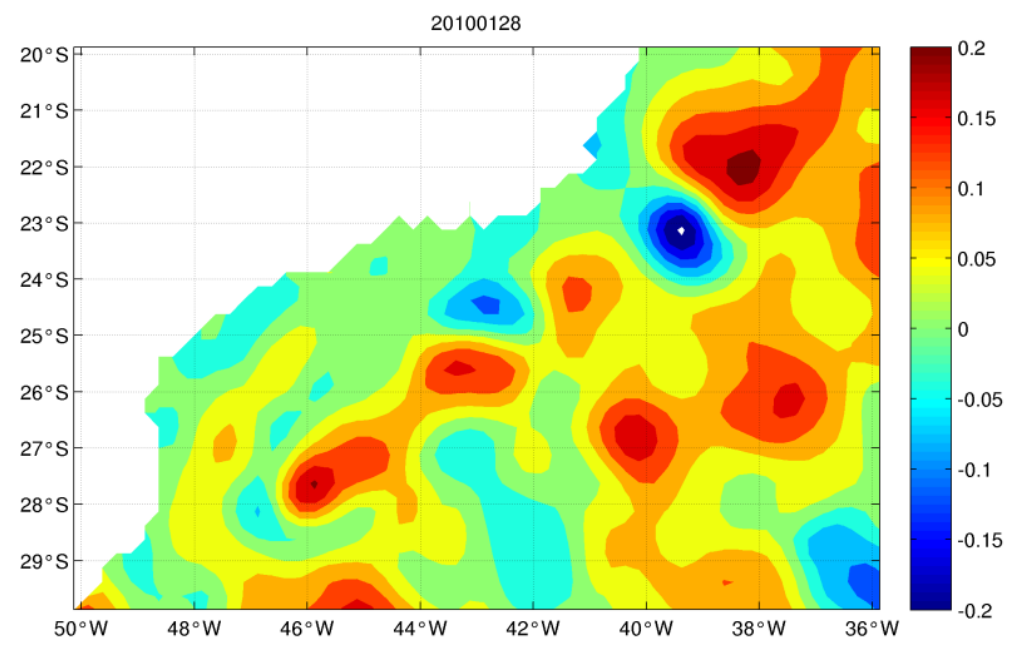

Figura 43: Imagem de altimatria de 28 de janeiro de 2010. Nota-se a presença vórtices ciclônicos e anticiclônico ao largo da PCSE.

\section{Escalas de variabilidade temporal}

Foi possível identificar no espectro de frequências do vento grande variabilidade na escala sinóptica, ausente nos demais dados devido à estratégia de amostragem (Figura 44). Esta variabilidade está associada à passagem de frentes frias, que tem período de ocorrência médio de 8 dias ao longo do ano. De acordo com Aidar et al. (1993), as frentes estão associadas à desestabilização da coluna de água, causando remobilização do substrato e mistura turbulenta, podendo introduzir nutrientes novos na coluna de água. Por outro lado, as frentes frias constituem condições desfavoráveis para sustentar a intrusão da ACAS, uma vez que revertem os ventos e as correntes sobre a plataforma, favorecendo a convergência de águas superficiais pobres em nutrientes. Gaeta et al. (1999) estudando as variabilidades da biomassa fitoplanctônica e da produtividade na região de Ubatuba durante 33 dias no verão detectaram ciclos de 8,25 e 6,6 dias, e concluíram que estes períodos explicam 32 \% da variância da biomassa fitoplanctônica. Verificaram, também, que os ventos tiveram períodos entre 8,3 e 11 dias e o nitrogênio total um atraso de 4 a 6 dias em relação ao pico de biomassa fitoplanctônica. No presente trabalho foram identificados períodos de 11,8 e 5 dias tanto no vento paralelo como no vento perpendicular à costa. Assim, a variabilidade associada à escala sinóptica explicaria grande parte da variância das propriedades bioquímicas registradas na área de estudo, e a ausência de dados nesta frequência, pode interferir nas correlações obtidas com a presente série. 


\section{Espectro de períodos significativos}
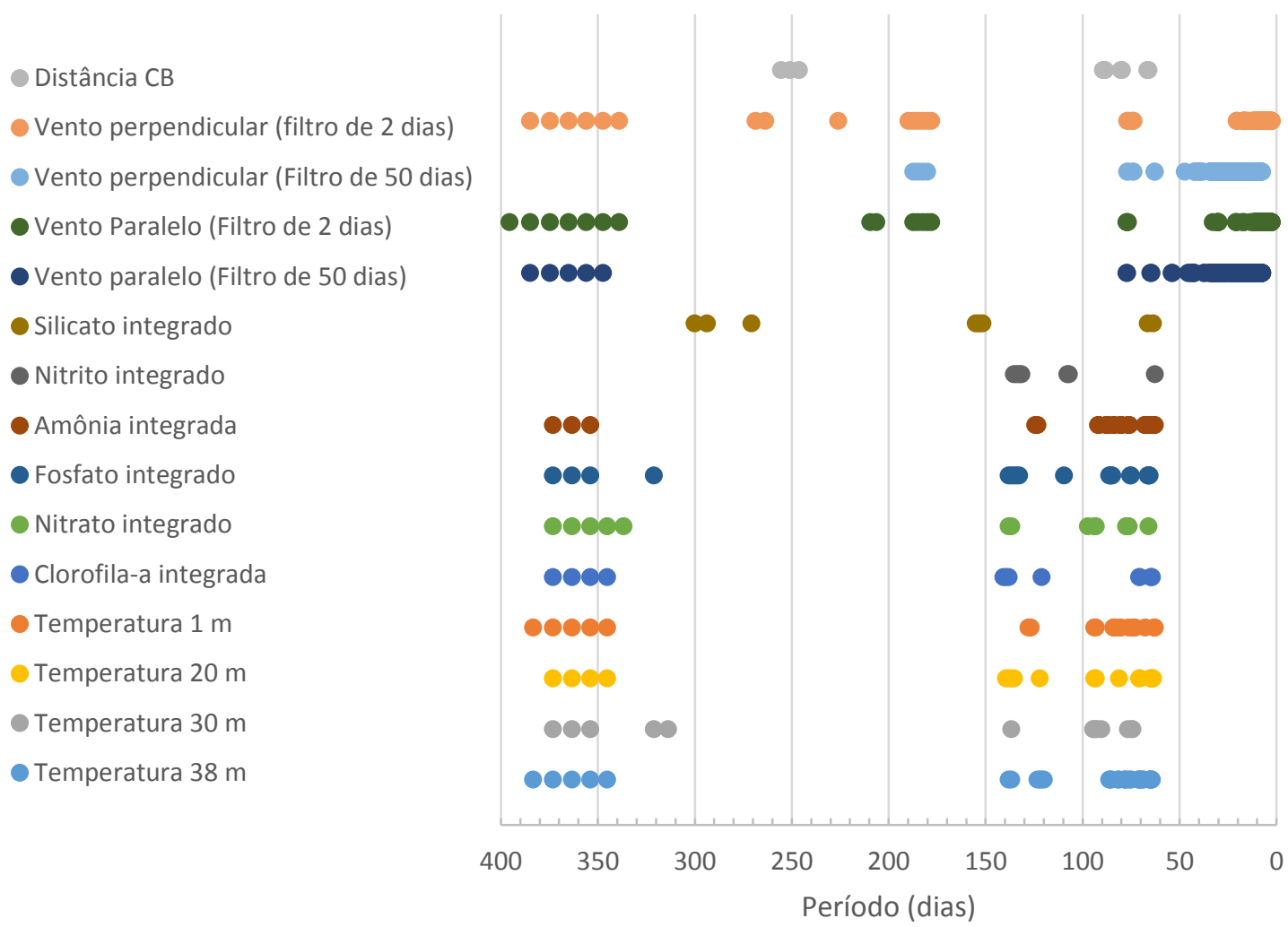

Figura 44: Diagrama dos períodos significativos da série de dezembro de 2004 a abril de 2014 de ventos, distância da $C B$ e dados obtidos in situ. As cores relacionam as variáveis aos períodos significativos e a abcissa indica o período.

A banda de frequência que equivale de 60 a 100 dias ocorre em todas as séries de dados analisados, com destaque para o período de 66 dias, presente em todas as séries exceto no vento perpendicular. Esta escala de tempo está relacionada a fenômenos de mesoescala oceânicos, como meandros e vórtices. De acordo com Pickart (1994), os meandros da Corrente do Golfo têm como principal frequência de variabilidade o período de 40 dias e podem gerar propagação de ondas de Rossby topográfica na mesma escala. Para Lee e Cornillon (1996), o principal período do meandramento da Corrente do Golfo foi 46 dias. Estudos feitos por Provost e Traon (1993) mostraram variabilidades de mesoescala na confluência de Brasil-Malvinas com períodos de 75 a 150 dias, consistente com as características dinâmicas de propagação de ondas de Rossby. No presente trabalho como estes ciclos também foram observados nos ventos, é provável que a variabilidade intrasazonal seja introduzida pelo vento remoto. 
A variabilidade intrasazonal atmosférica não tem escalas de tempo definidas, variando de 10 a 100 dias. O fenômeno mais conhecido é a Oscilação de Maden-Julian (OMJ), que se propaga para leste a partir do Pacífico com período entre 30 e 60 dias influenciando a convecção e precipitação. Resplandy et al. (2009) estudaram a fertilização da camada de mistura em uma cadeia de montanhas no Oceano Indico em resposta à OMJ e mostraram que a intensificação dos ventos decorrente de sua passagem aprofunda a camada de mistura, aumentando a oferta de nutrientes o que favorece o desenvolvimento da biomassa fitoplanctônica. A OMJ pode intensificar a Zona de Convergência do Atlântico Sul (ZCAS), fenômeno decorrente da convecção de umidade na baixa troposfera que cria uma intensa banda de nebulosidade orientada de noroeste para sudeste, sendo importante especialmente no verão, associada à precipitação (Kayano et al., 2009). Por outro lado, os estudos de Liebmann et al. (1999) evidenciaram que a ZCAS teve variabilidade de 50, 27, 16 e 8 dias.

$\mathrm{Na}$ análise de Wavelet é possível observar que em escalas entre 100 e 60 dias os ciclos são intermitentes, destacando-se os do vento perpendicular à costa em 2011. No WC foi possível identificar coerência de potencias nestas escalas entre diversas variáveis. No entanto, em relação ao vento paralelo e as demais variáveis, a coerência de fases nesta escala não foi constante, indicando que a influência do vento nestas escalas não é um processo linear. A WTX e WC da CB com as demais variáveis apresentaram maior consistência em relação às fases.

A análise de REDFIT mostrou que os dados obtidos in situ têm frequências recorrentes que não são observados nos dados remotos no intervalo entre 100 e 150 dias. Os TWC dos ventos paralelo e perpendicular também indicam que durante a série não houve ciclos nestas escalas. Em relação à distância da CB, apenas em 2012 houve uma ampla banda de frequências, com ciclos de 200 a 60 dias. Mesmo nas variáveis obtidas in situ é possível observar que os ciclos são intermitentes em todas as escalas de tempo.

Na análise de Wavelet, as variáveis que tiveram maior regularidade foram o vento paralelo e a temperatura de fundo, marcadas pelo sinal sazonal. Analisando o TWX e o WC destas duas variáveis, é possível notar que estão em fase durante toda a série nesta escala. Esta informação é confirmada pela correlação positiva entre estas variáveis. Apesar do nitrato não ter ciclo sazonal constante, a TWX mostra que esteve em anti-fase com o vento paralelo em toda série nesta escala, que é confirmado pela correlação. $\mathrm{O}$ mesmo pode ser observado com relação ao fosfato. 
A compreensão dos mecanismos de trocas de massas de água entre oceano profundo e plataforma ainda é pouco compreendida (Brink, 1998). A análise da TWX e WC da distância da CB com as demais variáveis na escala sazonal teve coerência com a temperatura de fundo e com o nitrato. No entanto, as fases se inverteram a partir de 2010. Analisando a distância da CB, é possível notar que na primeira metade da série, a frente da $\mathrm{CB}$ se encontrava mais próxima à costa e, na segunda metade, se encontrava mais distante. Isto pode ter influenciado na mudança das fases, sugerindo que houve uma mudança na dinâmica de trocas de massas de água entre oceano profundo e plataforma a partir de 2010. 


\section{Conclusões}

Os resultados do presente trabalho permitem inferir que a distribuição das massas de água na PCSE é controlada por forçantes meteorológicas e hidrodinâmicas, que ocorrem em diferentes escalas de tempo, contribuindo para eventos de eutrofização do ecossistema costeiro. A principal forçante é o vento remoto, que atua em escala sinóptica a sazonal. Apesar de haver variações ao longo da série, os ventos de nordeste predominam em todas as estações do ano, causando divergência costeira e o consequente processo de ressurgência. A componente do vento paralela à costa explicou $49 \%$ da variabilidade da temperatura de fundo, indicando que o vento remoto controla grande parte da dinâmica na plataforma. A componente do vento perpendicular à costa, de um modo geral, não tem relação linear com a distribuição das propriedades físico-químicas da coluna de água, portanto pode ser responsável pelos processos de turbulência e redistribuição dessas propriedades.

A influência dos ventos na variabilidade hidrográfica e bioquímica varia com a profundidade e época do ano, pois sua contribuição depende da distribuição sazonal das massas de água costeiras e de eventos de mesoescala relacionados à dinâmica da CB na quebra da plataforma. Na primavera, a ressurgência remota parece ser o principal processo de intrusão da ACAS ao largo de Ubatuba. A escala temporal do transporte desta massa de água é maior que a escala de assimilação dos nutrientes pelos fitoplâncton. Assim, na primavera em Ubatuba os ventos de nordeste atuam no resfriamento da coluna de água, mas não apresentam correlação com o fluxo de nutrientes. Após o evento de intrusão remota, no verão, inicia-se o processo de intrusão local, que favorece a introdução de novos nutrientes na zona eufótica. As correlações no verão indicam que os ventos de nordeste estão relacionados à elevação das concentrações de nutrientes no fundo e ao aumento da biomassa fitoplanctônica nas camadas superficiais.

O meandramento da CB também apresentou correlação positiva com a concentração de clorofila- $a$ e nutrientes ao largo de Ubatuba, indicando a importância das forçantes remotas na dinâmica costeira.

As periodicidades dos eventos da componente dos ventos paralelos à costa e dos eventos de intrusão foram regulares em escala sazonal. A temperatura de fundo e o vento paralelo estiveram em fase em toda a série analisada, enquanto os dados bioquímicos não apresentaram periodicidade constante, alternando as escalas de variabilidade ao longo da 
série estudada. Foram identificadas oscilações intrasazonais que podem estar associadas a fenômenos hidrodinâmicos de mesoescala e atmosféricos como a ZCAS e a OMJ. Variações interanuais, como as anomalias negativa de temperatura em 2007 e a positiva em 2010, também foram identificadas. As coerências espectrais apresentaram uma mudança de $180^{\circ}$ nas fases da temperatura de fundo e do nitrato, com relação à distância da $\mathrm{CB}$ no ano de 2010, fato estaria associado à anomalia positiva de temperatura registrada.

A análise espectral REDFIT revelou a existência de frequências comuns entre os dados obtidos in situ e os remotos. Esta análise teve resultados consistentes com os obtidos baseados na análise Wavelet. 


\section{Referências}

Aidar, E; Gaeta, S. A.; Gianesella-Galvão, S.M.F.; Kutner, M.B.B.; Teixeira, C. 1993. Ecossistema costeiro subtropical: nutrientes dissolvidos, fitoplâncton e cloroflla- $a$ e suas relações com as condições oceanográficas na região de Ubatuba, SP. Pub. Esp. Inst. Oceanogr., v. 10, n. 10, p. 9-43.

Amor, C. 2004. Intrusões da Água Central do Atlântico Sul sobre a Plataforma Continental situada entre a Ilha de São Sebastião (SP) e o Cabo de São Tomé (RJ). Tese de Doutorado. Universidade de São Paulo.

Austin, J. A. \& Barth, J. A.2002. Drifter Behavior on the Oregon-Washington Shelf during Downwelling-Favorable Winds*. J. Phys. Oceanogr., v. 32, n. 11, p. 3132-3144.

Austin, J. A. \& Lentz, S. J. 2002. The Inner Shelf Response to Wind-Driven Upwelling and Downwelling*. J. Phys. Oceanogr., v. 32, n. 7, p. 2171-2193.

Behrenfeld, M. J.;Boss, E.; Siegel, D.A.\& Shea, D.M.2005. Carbon-based ocean productivity and phytoplankton physiology from space. Global Biogeochem Cycles, v. 19, n. 1, p. 1-14

Benincà, E.; Huisman,J; Heerkloss, R.; Jöhnk, K.D.; Branco, P.; Van Nes, E.H.; Scheffer, M. \& Ellner, S.P.2008. Chaos in a long-term experiment with a plankton community. Nature, v. 451, n. 7180 , p. $822-825$.

Bracewell, R. N.; Buneman, O.; Hao, H.; Villasenor, J.1986. Fast two-dimensional Hartley transform. Proceedings of the IEEE, v. 74, n. 9, p. 1282-1283.

Brandini, F. P.; Nogueira Jr, M.; Simão,M.; Ugaz Codina, J.C.; Noernberg, M.A. 2014.Deep chlorophyll maximum and plankton community response to oceanic bottom intrusions on the continental shelf in the South Brazilian Bight. Continental Shelf Res., v. 89, p. 6175, set. 2014.

Brandini, F. P. 1988. Hydrography, phytoplankton biomass and photosynthesis in shelf and oceanic waters off southeastern brazil during autumn (may/june 1983). Bolm Inst. Ocenogr., v. 36, n. 694, p. 63-72.

Brandini, F.P; Moraes, C.L.B. \& Thamm, C.A. 1989. Shelf break upwelling, subsurface maxima of chlorophyll and nitrite, and vertical distribution of a Subtropical nano and microplankton community off Southeastern Brazil. In: Brandini, F.P. (org). Memórias do III Encontro Brasileiro de Plankton . Caiobá, UFPR. p.47-56.

Brandini, F. P.1990. Produção primária e características fotossintéticas do fitoplâncton na região sueste do Brasil. Braz. J. Oceanogr., v. 38, n. 2, p. 147-159.

Brink, K.H., 1998. Deep-sea forcing and exchange processes, in: The Sea. volume 10. chapter 6, pp. 151-167.

Brown, O. B. \& Minnett, P. J. 1999. MODIS Infrared Sea Surface Temperature Algorithm Theoretical Basis Document, Version 2.0. University of Miami, Miami, FL. 90 p.

Calado, L.; Da Silveira, I.C.A.; Gangopadhyay A.; Castro, B.M. 2010.Eddy-induced upwelling off Cape São Tomé (22옹, Brazil). Continental Shelf Res, v. 30, n. 10-11, p. 1181-1188.

Campos, E. J. D., Ikeda, Y., Castro, B. M., Gaeta, S. A., Lorenzzetti, J. A., Stevenson, M. R. 1996a. Experiment studies circulation in the Western South Atlantic. Eos, Transactions American Geophysical Union, v. 77, n. 27, p. 253-259.

Campos, E. J. D.; Lorenzzetti, J.A.; Stevenson, M.R.; Stech, J.L.\& Souza, R.B.1996.b Penetration of Waters from Brazil-Malvinas Confluence Region Along the South America Continental Shelf Up to $23^{\circ} \mathrm{S}$. An. Acad. Bras. Cien., v. 68, n. 1, p. 49-58. 
Campos, E. J. D.; Goncalves, J. E.; Ikeda, Y., 1995. Water mass characteristics and geostrophic circulation in the South Brazil Bight: Summer of 1991. J. of Geophy. Res. C. Oceans, v. 100, n. C9, p. 18537-18550.

Campos, E. J. D.; Velhote, D.; Da Silveira, I. C. A. 2000. Shelf break upwelling driven by Brazil current cyclonic meanders. Geoph. Res. Letters, v. 27, n. 6, p. 751-754.

Carbonel, C. A. A. \& Valentin, J. L. 1999. Numerical modelling of phytoplankton bloom in the upwelling ecosystem of Cabo Frio (Brazil). Ecol. Model., v. 116, n. 2-3, p. 135-148.

Cardon, S. Z., Iberall, A. S. 1970. Oscil- lations in biological systems. Curr. Mod. Biol. V.3, p.237-49.

Castelão, R. M.; Campos, E. J. D.; Miller, J. L. 2004. A Modelling Study of Coastal Upwelling Driven by Wind and Meanders of the Brazil Current. J. Coastal Res, v. 203, p. 662-671.

Castro, B. M.1996. Correntes e massas de água da plataforma continental norte de São Paulo. Tese de Livre Docência. Universidade de São Paulo, São Paulo, 248 p.

Castro, B. M.; Lorenzzetti,J. A.; Da Silveira, I.C.A \& Miranda, L.B. 2006. Estrutura termohalina e circulação na região entre o Cabo de São Tomé (RJ) e o Chuí (RS). In: ROSSIWONGTSCHOWSKI, C. L. B.; MADUREIRA, L. S. P. (Eds.). . O Ambiente Oceanográfico da Plataforma Continental e do Talude na Região Sudeste-Sul do Brasil. São Paulo: Edusp, p. 11-120.

Cavalcanti, I. F. A \& Kousky, V. E. 2009. Frentes Frias sobre o Brasil. In: Cavalcanti, I. F. et al. (Eds.). . Tempo e Clima no Brasil. São Paulo: Oficina de Textos, 2009.

Cerda, C.\& Castro, B. M. 2014. Hydrographic climatology of South Brazil Bight shelf waters between Sao Sebastiao $\left(24^{\circ} \mathrm{S}\right)$ and Cabo Sao Tome $\left(22^{\circ} \mathrm{S}\right)$. Cont.Shelf Res., v. 89, p. 514.

Chatfield, C. 1989. The analysis of time series: an introduction, London: Chapman and Hall,. p. 352.

Churchill, J., Cornillon, P. C., Milkowski, G. W. 1986. Cyclonic Eddy and Shelf-Slope Water Exchange Associated With a Gulf Stream Warm-Core Ring. J Geophys Res. V. 91, p. 9615-9623.

Ciotti, A. M.; Odebrecht, C.;Filmann, G. \& Möller Jr. O.O. 1995. Freshwater outflow and subtropical convergence influence on phytoplankton biomass on the southern Brazilian continental shelf. Cont. Shelf Res., v. 15, n. 14, p. 1737-1756.

Ciotti, A. M.; Mahiques, M. M.; Möller, O. O. 2014. The meridional gradients of the S-SE Brazilian continental shelf: Introduction to the special volume. Cont. Shelf Res., v. 89, p. $1-14$.

Da Silva, A.M., C. C. Young-Molling, and S. Levitus, 1994: Atlas of Surface Marine Data 1994 Vol. 3: Anomalies of Fluxes of Heat and Momentum. NOAA Atlas NESDIS 8. U.S. Gov. Printing Office, Wash., D.C., 413 pp.

Demers, S.; Legendre, L. \& Therriault, J. C. 1986. Phytoplankton responses to vertical tidal mixing. In: Tidal mixing and plankton dynamics. New York: Springer., p. 1-40

Dottori, M. \& Castro, B. M. 2009. The response of the Sao Paulo continental shelf, Brazil, to synoptic winds. Ocean Dyn., v. 59, n. 4, p. 603-614.

Dugdale, R. \& Goering, J. 1967. Uptake of new and regenerated forms of nitrogen in primary productivity. Limnol. Oceanogr, v. 12, n. 2, p. 196-206.

Dyck, A. \& Sumaila, U. 2010. Economic impact of global fish populations in the global fishery. J. Bioecon., v. 12, n. 3, p. 227-243. 
FAO.2009. The Sunken Billions: The Economic Justification for Fisheries Reform, World Bank and Food and Agriculture Organization. Washington D.C.

Fernandes, L. F.; Brandini, F.P.; Gutseit, K.S.; D’Oliveira Fonseca, A.L. \& Pellizzari, F. 1999. Benthic diatoms growing on glass slides in the Paranaguá Bay, Southern Brazil: taxonomic structure and seasonal variation. Insula, v. 28, p. 53-100.

Fernandes, L. F. \& Brandini, F. P. 200. Diatom associations in shelf waters off Paraná State, Southern Brazil: annual variation in relation to environmental factors. Braz. J. Oceanogr., v. 52, n. 1, p. 19-34.

Gaeta, S. A. 1999. Produção primária na região oeste do Atlântico Sul. Tese de Livre Docência. Universidade de São Paulo, São Paulo, 129 p.

Gaeta, S.A; Ribeiro, S.M.S; Metzler, P.M.; Francos, M.S. \& Abe, D.S. 1999. Environmental forcing on phytoplankton biomass and primary productivity of the coastal ecosystem in Ubatuba region, Southern Brazil. Rev. Bras. Oceanogr., v.47, n 1, p.11-27.

Gaeta, S.S.; Lorenzzetti, J.A.; Miranda, L.B.; Susini Ribeiro, S.M.; Pompeu, M; Araújo, C.E.S.1999b. The Vitória eddy and its relation to the phytoplankton biomass and primary productivity during the austral fall of 1995. Arch. Fish. Mar. Res., v.47, n 2-3, p.253-270.

García-Ruiz, R.; Lucena, J. \& Niell, F. X. 1999. Do bacteria regenerate phosphorus while decomposing seston? Mar. Fresh. Res., v. 50, n. 5, p. 459.

Garfield III, N.1990. The Brazil Current at Subtropical Latitudes. University of Rhode Island. 121p. (tese de doutorado).

Glenn, S.M. \& Ebbesmeyer, C.C. 1994. The structure and propagation of Gulf Stream frontal eddy along the North Carolina shelf break. J. Geophys. Res., v. 99, p 5029 - 5046.

Glover, D.M.; Jenkins, W.J. \& Doney, S. C.2011. Modeling methods for marine science. Cambridge University Press, 2011. p.554.

Grasshoff, K.; Kremling, K. \& Ehrhardt, M. 2009. Methods of seawater analysis. Third ed.Weinheim, Germany: Wiley-VCH.

Grinsted, A.; Moore, J. C. \& Jevrejeva, S. 2004. Application of the cross wavelet transform and wavelet coherence to geophysical time series. Nonlinear Proc. Geophys., v. 11, n. 5/6, p. 561-566.

Guinder V. A.; Popovich, C.A. \& Perillo, G.M.E. 2009. Short-term variability in the phytoplankton and physico-chemical variables in a high-tidal regime, Bahía Blanca Estuary, Argentina. Braz. J. Oceanogr, v. 57, n. 3, p. 249-258.

Hamilton, P. 1987. Summer upwelling on the southeastern continental shelf of the U.S.A during 1981 - The structure of shelf and Gulf Stream motions in the Georgia Bight. Prog. Oceanogr., v.19, p.329 -351.

Hu, C.; Lee, Z. \& Franz, B. 2012. Chlorophyll a algorithms for oligotrophic oceans: A novel approach based on three-band reflectance difference. J. Geophys. Res. Oceans, v. 117, n. 1.

Jahnke, R. A. 2010. Global Synthesis. In: LIU, K.-K. et al. (Eds.). Carbon and nutrient fluxes in continental margins. Berlim: Springer, 757p.

Jenouvrier S, Weimerskirch H, Barbraud C, Park Y-H, Cazelles B. 2005. Evidence of a shift in the cyclicity of Antarctic seabird dynamics linked to climate. Proceedings. Biological sciences / The Royal Society, v. 272, n. 1566, p. 887-895

Kampel, M.; Lorenzzetti, J. A.; Gaeta, S.A.; Araujo, C. E. S. \& Assireu, A. T. 2000. Use of satellite data for studying and monitoring the southeast coast of Brazil. In: IX Simposio Latinoamericano en Percepcion Remota y Sistemas de Informacion Spacial. Puerto Iguazu, Missiones, Argentina, pp 1033-1044 (CD-Rom). 
Keitt,T. H.; \& Fischer, J. 2006. Detection of scale-specific community dynamics using wavelets. Ecol., v. 87, n. 11, p. 2895-2904.

Kimura, S. 1997. Biological production in meso-scale eddies caused by frontal disturbances of the Kuroshio Extension. ICES J. Mar Sci , v. 57, n. 1, p. 133-142.

Lee, T \& Cornillon, P. 1996. Propagation of Gulf Stream meanders between $74^{\circ}$ and $70^{\circ} \mathrm{W}$. AMS - American Metereological Society, v. 26, p.205-224.

Lee, T.N. \& Pietrafesa, L.J. 1987.Summer upwelling on the southeastern continental shelf of the U.S.A. during 1981. Circulation. Prog. Oceanogr., vol19, p 267-312.

Lee, T. N.; Atkinson, L. P.\&Legeckis, R.1981. Observations of a Gulf Stream frontal eddy on the Georgia continental shelf, April 1977. Deep Sea Res. Part A. Oceanogr. Res. Papers, v. 28, n. 4, p. 347-378.

Lentz, S. J. 2003. Temperature and salt balances on Georges Bank February-August 1995. J. Geophys. Res., v. 108, n. C11, p. GLO 7-1-GLO 7-17.

Lentz, S. J. 2001. The Influence of Stratification on the Wind-Driven Cross-Shelf Circulation over the North Carolina Shelf*. J. Phys. Oceanogr., v. 31, n. 9, p. 2749-2760.

Liebmann, B., Kiladis, G. M., Marengo, J. A., Ambrizzi, T., Glick, J. D. 1999. Submonthly convective variability over South America and the South Atlantic convergence zone. J Climate, v. 12, n. 7, p. 1877-1891,.

Lomb, N. R. 1976. Least-squares frequency analysis of unequally spaced data. Astrophys. Space Sci, v. 39, n. 2, p. 447-462.

Longhurst, A.; Sathyendranath, S.; Platt, T. \& Caverhill, C. 1995. An estimate of global primary production in the ocean from satellite radiometer data. J. Plankton Res., v. 17, n. 6, p. $1245-1271$.

Lorenzzetti, J. A. \& Gaeta, S. A. 1996. The Cape Frio Upwelling Effect over the South Brazilian Bight Northern Sector Shelf Waters: a Study using AVHRR Images. In $18^{\circ}$ International Society of Photogrametry and Remote Sensing (ISPRS) Congress.Viena, p. 448-453.

Mahiques, M. M.; De Mello e Sousa, S.H.; Veronese Furtado, V.; Gonsalez Tessler, M.; De Lima Toledo, F.A.;. Burone, L; Lopes Figueira, R.C; Klein, D.A,; Martins, C.C. \& Vicente Alves, D.P. 2010. The Southern Brazilian shelf: general characteristics, quaternary evolution and sediment distribution. Braz. J. Oceanogr, v. 58, n. 25, p. 25-34, 2010.

Mitchum, G. T. \& Clarke, A. J. 1986. The Frictional Nearshore Response to Forcing by Synoptic Scale Winds. J. Phys. Oceanogr., v. 16, n. 5, p. 934-946.

Müller C, Agerbirk N, Olsen CE, Boevé J-L, Schaffner U, Brakefield PM 2001Journal of Chemical Ecology, v. 27, n.12, p. 2505-2516.

New, A. L. \& Pingree, R. D.1990. Large-amplitude internal soliton packets in the central Bay of Biscay. Deep Sea Res. Part A. Oceanogr. Res. Papers, v. 37, n. 3, p. 513-524.

Nicholls, R. J.; Small, C. 2002. Improved estimates of coastal population and exposure to hazards released. Eos Trans. AGU, v. 83, n. 28, p. 301-305.

Oliveira, A. S.1986. Interações entre sistemas frontais na América do Sul e convecção na Amazônia. Dissertação de Mestrado, Instituto de Pesquisas Espaciais, São José dos Campos.

Oliveira, G. Q.2009. Análise temporal da concentração de clorofila- $a$ e do campo de ventos na Plataforma Interna de Ubatuba (SP). Trabalho de conclusão de curso. Universidade de São Paulo, São Paulo, 61p. 
Olson, D. B.; Backus, R. H. 1985. The concentrating of organisms at fronts: A cold-water fish and a warm-core Gulf Stream ring. J. Mar. Res., v. 43, n. 1, p. 113-137.

Osgood, K. E.; Bane, J. M.; Dewar, W. K. 1987. Vertical velocities and dynamical balances in Gulf Stream meanders. J. Geophys. Res., v. 92, n. C12, p. 13029.

Overland, J. E.; Percival, D. B.; Mofjeld, H. O. 2006. Regime shifts and red noise in the North Pacific. Deep-Sea Res. Part I: Oceanogr. Res. Papers, v. 53, n. 4, p. 582-588.

Palóczy, A.; Da Silveira, I.C.A.; Castro, B.M. \& Calado, L1.2013. Coastal upwelling off Cape São Tomé $\left(22^{\circ} \mathrm{S}\right.$, Brazil): The supporting role of deep ocean processes. Continental Shelf Res., v. 89, p. 38-50, 2013.

Paranhos, R. 1996. Alguns métodos para análise da água. Cadernos didáticos UFRJ, Rio de Janeiro, 200p.

Pauly, D.; Christensen, V.; Guénette, S.; Pitcher, T.J.; Rashid Sumalia,U.; Walters, C.J.; Watson, R. \& Zeller, D. 2002. Towards sustainability in world fisheries. Nature, v. 418, n. 6898, p. 689-695.

Pickart, R. 1994. Interaction of the Gulf Stream and Deep Western Boundary Current where they cross. J. Geophys. Res. v. 99, n. C12, p. 25155-25164.

Pimenta, F. M.; Campos, E.J.D.; Miller, J.L. \& Piola, A.R. 2005. A numerical study of the Plata River plume along the southeastern South American continental shelf. Braz. J. Oceanogr, v. 53, n. 3-4.

Piola, A. R. Campos, EJ.D.; Möller, O.O.; Charo, M \& Martinez, C.2000. The Subtropical Shelf Front off eastern South America. J. Geophys. Res., v. 105, p. 6565 - 6578.

Platt, T.; Fuentes-Yaco, C. \& Frank, K. T. 2003. Marine ecology: Spring algal bloom and larval fish survival. Nature, v. 423, n. 6938, p. 398-399.

Power, M. E. 1992. Top-Down and Bottom-Up Forces in Food Webs : Do Plants Have Primacy? Ecological Society of America. Ecology, v. 73, n. 3, p. 733-746.

Provost, C. \& Le Traon, P.Y. 1993. Spatial and Temporal Scales in Altimetric variability in the Brazil-Malvinas Current confluence region - dominance of the semiannual period and large spatial scales. J. Geophy. Res -Oceans, v.98, n. C10, p. $18037-18051$.

Resplandy, L., Vialard, J., Lévy, M., Aumont, O. and Dandonneau, Y. 2009. Seasonal and intraseasonal biogeochemical variability in the thermocline ridge of the southern tropical Indian Ocean..J. Geophys.1 Res. V.114, p. 0148-0227.

Saldanha, F.M.P. 1993 Simulação da mistura vertical de massas de água da região costeira de Ubatuba (SP): efeitos sobre a produção primária e biomassa fitoplanctônica. Dissertação de Mestrado. Universidade de São Paulo, São Paulo, 250p.

Saldanha-Corrêa, F.M.P. 1999. Aspectos da variação vertical e temporal da produção primária e biomassa fitoplanctônica, em uma estação fixa na região costeira de São Sebastião (SP). Tese de Doutorado. Universidade de São Paulo, São Paulo, 99p.

Samelson, R. M. 2003. Meridional overturning as a "pump and valve" system. In: NearBoundary Processes and Their Parameterization: Proc.'Aha Huliko'a Hawaiian Winter Workshop. p. 205-209.

Sarmiento, J. L. \& Gruber, N. 2006. Ocean Biogeochemical Dynamics. Oxford: Princeton University Press.

Sasaki, K.; Yamashita, K.; Kuroda K. 1985. Fine distributions of nutrients in the Kuroshio front, south of Cape Shionomisaki. Japan Bull Tokai Regional Fish Res Lab. v.118, p.1-10.

Satyamurty, P.; Nobre, C. A.; Dias, P. L. S.1998. South America. Meteorology of the Southern Hemisphere, Meteorological Monographs, v. 27, n. 49, p. 119-140. 
Schulz, M \& Stattegger, K. 1997. SPECTRUM: Spectral analysis of unevenly spaced paleoclimatic time series. Computers and Geociences v. 23 (9), p. $929-945$.

Schulz, M. \& Mudelsee, M. 2002. REDFIT: estimating red-noise spectra directly from unevenly spaced paleoclimatic time series. Computers e Geosciences, v. 28, p. 421-426.

Simpson, J. H.; Sharpler, J. 2012. Introduction to the physical and biological oceanography of shelf seas. Cambridge: Cambridge University Press, 2012.

Schmid,C.; Schafer, H.; Podestá,G. \& Zenk, W. 1995. The Vitoria eddy and its relation to the Brazil current. J. Phys.Oceanogr. v.25, n11, p.2532-2546.

Stech, J. L. \& Lorenzzetti, J. A. 1992. The response of the South Brazil Bight to the passage of wintertime cold fronts. J. Geophys. Res., v. 97, n. C6, p. 9507.

Stech, J. L., Lorenzzetti, J. A., Mello Filho, W. L. 2007. Um estudo sobre a variabilidade espaço/temporal da frente interna da corrente do Brasil usando imagens AVHRR/NOAA. Anais XIII Simpósio Brasileiro de Sensoriamento Remoto, Florianópolis, Brasil, INPE, p. $4743-4750$.

Szoeke, R. A. De \& Richman, J. G. 1984. On Wind-Driven Mixed Layers With Strong Horizontal Gradients - A Theory With Application To Coastal Upwelling. J. Phys. Oceanogr., V. 14 , N. 2, P. 364-377.

Therriault, J. C.; Lawrence, D. J. \& Platt, T. 1978. Spatial variability of phytoplankton turnover in relation to physical processes in a coastal environment. Limnol. Oceanogr., v. 23, n. 5, p. $900-911$.

Tintoré, J. Wang, D.P.; Garcia, E \& Viudez, A. Near-inertial motions in the coastal ocean. J. Mar. Syst., v. 6, n. 4, p. 301-312, 1995.

Turner, R. K.; Subak, S. \& Adger, W. N. 1996. Pressures, trends, and impacts in coastal zones: Interactions between socioeconomic and natural systems. Environmental Management, v. 20, n. 2 , p. 159-173.

Vasseur, D. A.; Fox, J. W. 2007.Environmental fluctuations can stabilize food web dynamics by increasing synchrony. Ecol. Letters, v. 10, n. 11, p. 1066-1074.

Welschmeyer, N. A. 1994. Fluorometric analysis of chlorophyll $a$ in the presence of chlorophyll $b$ and pheopigments. Limnol. Oceanogr., v. 39, n. 8, p. 1985-1992.

Wittemyer, G.; Polansky, L.; Douglas-Hamilton, I. \& Getz, W.M. 2008. Disentangling the effects of forage, social rank, and risk on movement autocorrelation of elephants using Fourier and wavelet analyses. Proceedings of the National Academy of Sciences of the United States of America, v. 105, n. 49, p. 19108-19113.

Yoder, J. A. \& Atkinson, L. P. 1981. Role of Gulf Stream frontal eddies in forming phytoplankton patches on the outer southeastern shelf. Limnol. Oceanogr., v. 26, n. 6, p. 1103-1110.

Zhang, H. M., Reynolds, R. W., Lumpkin, R., Molinari, R., Arzayus, K., Johnson, M., \& Smith, T. M. 2009 An integrated global observing system for sea surface temperature using satellites and in situ data: Research to operations. Bull. of the American Meteor. Society, v. 90, n. 1 , p. 31-38.

Zillmann, S. M. S. 1990. Distribuição sazonal do fitoplâncton na radial entre Ilha Anchieta e Ilha da Vitória (Lat. $23^{\circ} 31^{\prime} \mathrm{S}$; Long. $45^{\circ} 06^{\prime} \mathrm{W}$ a Lat. $23^{\circ} 45^{\prime} \mathrm{S}$, Long. $45^{\circ} 01^{\prime} \mathrm{W}$ ) na região de Ubatuba, São Paulo. Dissertação de mestrado. Universidade de São Paulo. 


\section{ANEXO}

Tabela 2: Diferença, em dias, entre as datas de coleta e as datas das imagens de satélite selecionadas para compor o mosaico que representar o dia de coleta.

\begin{tabular}{|c|c|c|c|c|c|c|c|c|}
\hline \multirow{2}{*}{ UBA } & \multirow{2}{*}{\multicolumn{2}{|c|}{\begin{tabular}{|c|c|} 
Dia médio \\
dos \\
Dia \\
Coleta \\
$\begin{array}{c}\text { composites } \\
\text { a partir do } \\
\text { dia de } \\
\text { coleta }\end{array}$ \\
\end{tabular}}} & \multicolumn{2}{|c|}{ Extremos a partir do dia de coleta } & \multirow[b]{2}{*}{$\begin{array}{c}\text { Diferença } \\
\text { entre a } \\
\text { média e a } \\
\text { coleta }\end{array}$} & \multirow[b]{2}{*}{$\begin{array}{l}\text { Diferença } \\
\text { extremo e } \\
\text { coleta }\end{array}$} & \multirow[b]{2}{*}{$\begin{array}{l}\text { Numero de } \\
\text { composites }\end{array}$} & \multirow[b]{2}{*}{ Ano } \\
\hline & & & $\begin{array}{l}\text { Dia do } \\
\text { composite } \\
\text { superior }\end{array}$ & $\begin{array}{l}\text { Dia do } \\
\text { composite } \\
\text { inferior }\end{array}$ & & & & \\
\hline 1 & 0 & 2 & 3 & 1 & 2 & 3 & 3 & 2004 \\
\hline 2 & 52 & 53 & 56 & 49 & 1 & 4 & 4 & 2005 \\
\hline 3 & 68 & 66 & 67 & 65 & -2 & 3 & 3 & 2005 \\
\hline 4 & 108 & 107 & 108 & 106 & -1 & 2 & 3 & 2005 \\
\hline 5 & 146 & 145 & 145 & 145 & -1 & 1 & 1 & 2005 \\
\hline 6 & 165 & 166 & 167 & 165 & 1 & 2 & 3 & 2005 \\
\hline 7 & 179 & 178 & 179 & 177 & -1 & 2 & 2 & 2005 \\
\hline 8 & 214 & 213 & 215 & 211 & -1 & 3 & 3 & 2005 \\
\hline 9 & 243 & 243 & 244 & 241 & 0 & 2 & 4 & 2005 \\
\hline 10 & 292 & 294 & 295 & 291 & 2 & 3 & 3 & 2005 \\
\hline 11 & 309 & 307 & 312 & 303 & -2 & 6 & 3 & 2005 \\
\hline 12 & 335 & 337 & 339 & 335 & 2 & 4 & 3 & 2005 \\
\hline 13 & 360 & 359 & 362 & 356 & -1 & 4 & 4 & 2005 \\
\hline 14 & 409 & 408 & 412 & 405 & -1 & 5 & 7 & 2006 \\
\hline 15 & 423 & 421 & 425 & 419 & -2 & 5 & 4 & 2006 \\
\hline 16 & 465 & 465 & 466 & 464 & -1 & 2 & 3 & 2006 \\
\hline 17 & 486 & 488 & 489 & 487 & 2 & 3 & 2 & 2006 \\
\hline 18 & 510 & 510 & 512 & 509 & 0 & 2 & 4 & 2006 \\
\hline 19 & 542 & 543 & 544 & 542 & 1 & 2 & 3 & 2006 \\
\hline 20 & 583 & 583 & 584 & 582 & -1 & 2 & 3 & 2006 \\
\hline 21 & 627 & 626 & 628 & 624 & -1 & 4 & 4 & 2006 \\
\hline 22 & 656 & 656 & 658 & 654 & -1 & 3 & 5 & 2006 \\
\hline 23 & 689 & 688 & 692 & 683 & -1 & 7 & 8 & 2006 \\
\hline 24 & 711 & 712 & 713 & 711 & 1 & 2 & 2 & 2006 \\
\hline 25 & 731 & 732 & 736 & 729 & 1 & 5 & 7 & 2006 \\
\hline 26 & 774 & 774 & 775 & 773 & 0 & 1 & 2 & 2007 \\
\hline 27 & 794 & 794 & 796 & 793 & 0 & 2 & 4 & 2007 \\
\hline 28 & 822 & 819 & 820 & 818 & -3 & 4 & 2 & 2007 \\
\hline 29 & 856 & 856 & 859 & 852 & 0 & 4 & 3 & 2007 \\
\hline 30 & 905 & 906 & 907 & 905 & 1 & 2 & 3 & 2007 \\
\hline 31 & 929 & 926 & 932 & 921 & -3 & 8 & 6 & 2007 \\
\hline 32 & 952 & 951 & 952 & 951 & -1 & 1 & 2 & 2007 \\
\hline 33 & 992 & 996 & 1001 & 987 & 4 & 9 & 5 & 2007 \\
\hline 34 & 1013 & 1008 & 1010 & 1006 & -6 & 7 & 4 & 2007 \\
\hline
\end{tabular}




\begin{tabular}{|c|c|c|c|c|c|c|c|c|}
\hline 35 & 1040 & 1033 & 1033 & 1033 & -7 & 7 & 1 & 2007 \\
\hline 36 & 1062 & 1061 & 1062 & 1061 & -1 & 1 & 2 & 2007 \\
\hline 37 & 1102 & 1102 & 1106 & 1099 & 0 & 4 & 5 & 2007 \\
\hline 38 & 1139 & 1134 & 1138 & 1131 & -5 & 8 & 4 & 2008 \\
\hline 39 & 1172 & 1167 & 1167 & 1166 & -6 & 6 & 2 & 2008 \\
\hline 40 & 1194 & 1194 & 1195 & 1193 & 0 & 1 & 2 & 2008 \\
\hline 41 & 1229 & 1230 & 1231 & 1229 & 1 & 2 & 2 & 2008 \\
\hline 42 & 1242 & 1244 & 1244 & 1243 & 2 & 2 & 2 & 2008 \\
\hline 43 & 1285 & 1285 & 1286 & 1284 & 0 & 1 & 3 & 2008 \\
\hline 44 & 1314 & 1314 & 1314 & 1314 & 0 & 0 & 1 & 2008 \\
\hline 45 & 1342 & 1340 & 1340 & 1339 & -3 & 3 & 2 & 2008 \\
\hline 46 & 1361 & 1361 & 1362 & 1360 & 0 & 1 & 2 & 2008 \\
\hline 47 & 1403 & 1401 & 1403 & 1399 & -2 & 4 & 2 & 2008 \\
\hline 48 & 1431 & 1429 & 1435 & 1424 & -3 & 7 & 4 & 2008 \\
\hline 49 & 1462 & 1458 & 1458 & 1457 & -5 & 5 & 2 & 2008 \\
\hline 50 & 1511 & 1512 & 1512 & 1511 & 1 & 1 & 2 & 2009 \\
\hline 51 & 1531 & 1531 & 1533 & 1528 & 0 & 3 & 3 & 2009 \\
\hline 52 & 1552 & 1554 & 1554 & 1553 & 2 & 2 & 2 & 2009 \\
\hline 53 & 1578 & 1580 & 1581 & 1579 & 2 & 3 & 3 & 2009 \\
\hline 54 & 1622 & 1622 & 1622 & 1621 & 0 & 1 & 2 & 2009 \\
\hline 55 & 1650 & 1650 & 1651 & 1649 & 0 & 1 & 3 & 2009 \\
\hline 56 & 1691 & 1697 & 1697 & 1696 & 6 & 6 & 2 & 2009 \\
\hline 57 & 1720 & 1720 & 1720 & 1719 & 0 & 1 & 2 & 2009 \\
\hline 58 & 1774 & 1777 & 1777 & 1776 & 3 & 3 & 2 & 2009 \\
\hline 59 & 1809 & 1804 & 1807 & 1802 & -5 & 7 & 3 & 2009 \\
\hline 60 & 1825 & 1827 & 1830 & 1823 & 2 & 5 & 3 & 2009 \\
\hline 61 & 1874 & 1879 & 1879 & 1879 & 5 & 5 & 1 & 2010 \\
\hline 62 & 1935 & 1934 & 1936 & 1933 & -1 & 3 & 2 & 2010 \\
\hline 63 & 1949 & 1948 & 1949 & 1948 & -1 & 2 & 2 & 2010 \\
\hline 64 & 2020 & 2021 & 2022 & 2020 & 1 & 2 & 2 & 2010 \\
\hline 65 & 2034 & 2033 & 2034 & 2033 & -1 & 2 & 2 & 2010 \\
\hline 66 & 2068 & 2068 & 2070 & 2066 & -1 & 3 & 2 & 2010 \\
\hline 67 & 2126 & 2127 & 2130 & 2125 & 1 & 4 & 6 & 2010 \\
\hline 68 & 2145 & 2145 & 2148 & 2142 & -1 & 4 & 7 & 2010 \\
\hline 69 & 2159 & 2156 & 2158 & 2153 & -4 & 7 & 3 & 2010 \\
\hline 70 & 2189 & 2191 & 2192 & 2190 & 2 & 3 & 2 & 2010 \\
\hline 71 & 2238 & 2239 & 2240 & 2238 & 1 & 2 & 3 & 2011 \\
\hline 72 & 2264 & 2264 & 2267 & 2261 & 0 & 3 & 7 & 2011 \\
\hline 73 & 2299 & 2295 & 2297 & 2294 & -4 & 5 & 3 & 2011 \\
\hline 74 & 2320 & 2320 & 2321 & 2319 & 0 & 1 & 2 & 2011 \\
\hline 75 & 2348 & 2351 & 2353 & 2349 & 3 & 5 & 4 & 2011 \\
\hline 76 & 2369 & 2369 & 2372 & 2366 & 0 & 3 & 7 & 2011 \\
\hline
\end{tabular}




\begin{tabular}{|c|c|c|c|c|c|c|c|c|}
\hline 77 & 2406 & 2407 & 2408 & 2406 & 1 & 2 & 3 & 2011 \\
\hline 78 & 2440 & 2436 & 2436 & 2436 & -4 & 4 & 1 & 2011 \\
\hline 79 & 2467 & 2468 & 2471 & 2466 & 1 & 4 & 2 & 2011 \\
\hline 80 & 2509 & 2509 & 2512 & 2507 & 0 & 3 & 4 & 2011 \\
\hline 81 & 2538 & 2538 & 2540 & 2535 & 0 & 3 & 4 & 2011 \\
\hline 82 & 2551 & 2548 & 2549 & 2548 & -3 & 3 & 2 & 2011 \\
\hline 83 & 2593 & 2596 & 2599 & 2592 & 3 & 6 & 4 & 2012 \\
\hline 84 & 2614 & 2609 & 2610 & 2608 & -5 & 6 & 3 & 2012 \\
\hline 85 & 2649 & 2648 & 2649 & 2647 & -1 & 2 & 3 & 2012 \\
\hline 86 & 2679 & 2678 & 2679 & 2676 & -2 & 3 & 4 & 2012 \\
\hline 87 & 2714 & 2716 & 2717 & 2714 & 2 & 3 & 4 & 2012 \\
\hline 88 & 2733 & 2729 & 2731 & 2726 & -5 & 7 & 2 & 2012 \\
\hline 89 & 2770 & 2763 & 2763 & 2763 & -7 & 7 & 1 & 2012 \\
\hline 90 & 2811 & 2811 & 2811 & 2811 & 0 & 0 & 1 & 2012 \\
\hline 91 & 2825 & 2824 & 2827 & 2822 & -1 & 3 & 4 & 2012 \\
\hline 92 & 2873 & 2870 & 2880 & 2865 & -3 & 8 & 4 & 2012 \\
\hline 93 & 2894 & 2894 & 2903 & 2887 & 0 & 9 & 3 & 2012 \\
\hline 94 & 2917 & 2918 & 2921 & 2914 & 1 & 4 & 4 & 2012 \\
\hline 95 & 2952 & 2952 & 2959 & 2948 & 0 & 7 & 8 & 2013 \\
\hline 96 & 3000 & 2999 & 3002 & 2996 & -1 & 4 & 7 & 2013 \\
\hline 97 & 3028 & 3027 & 3030 & 3024 & -1 & 4 & 7 & 2013 \\
\hline 98 & 3042 & 3041 & 3043 & 3039 & -1 & 3 & 5 & 2013 \\
\hline 99 & 3071 & 3070 & 3071 & 3068 & -1 & 3 & 2 & 2013 \\
\hline 100 & 3111 & 3111 & 3111 & 3110 & 0 & 1 & 2 & 2013 \\
\hline 101 & 3135 & 3134 & 3135 & 3133 & -1 & 2 & 3 & 2013 \\
\hline 102 & 3167 & 3168 & 3169 & 3166 & 1 & 2 & 2 & 2013 \\
\hline 103 & 3196 & 3198 & 3198 & 3197 & 2 & 2 & 2 & 2013 \\
\hline 104 & 3239 & 3236 & 3242 & 3233 & -3 & 6 & 4 & 2013 \\
\hline 105 & 3274 & 3272 & 3272 & 3272 & -2 & 2 & 1 & 2013 \\
\hline 106 & 3287 & 3290 & 3291 & 3288 & 3 & 4 & 3 & 2013 \\
\hline 107 & 3328 & 3327 & 3328 & 3326 & -2 & 3 & 2 & 2014 \\
\hline 108 & 3363 & 3361 & 3364 & 3359 & -2 & 5 & 6 & 2014 \\
\hline 109 & 3390 & 3393 & 3394 & 3393 & 3 & 4 & 2 & 2014 \\
\hline 110 & 3420 & 3420 & 3426 & 3415 & 0 & 6 & 2 & 2014 \\
\hline
\end{tabular}

